\title{
THE RELATIONSHIPS OF THE SALAMANDERS OF THE GENUS PLETHODON
}

\author{
By \\ RICHARD HIGHTON
}

\begin{abstract}
A DISSERTATION PRESENTED TO THE GRADUATE COUNCIL OF THE UNIVERSITY OF FLORIDA

IN PARTIAL FULFILLMENT OF THE REQUIREMENTS FOR THE DEGREE OF DOCTOR OF PHILOSOPHY
\end{abstract}

UNIVERSITY OF FLORIDA

June, 1956 


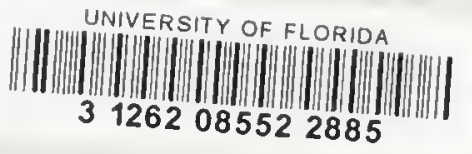


THE RFTATTON BETWEEN NUIBER OF COSTRL GHOOVES ALT TRUNK

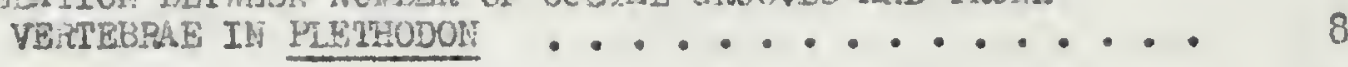

PTGLITLATON IN THE GENUS PLETHODON $\ldots 12$

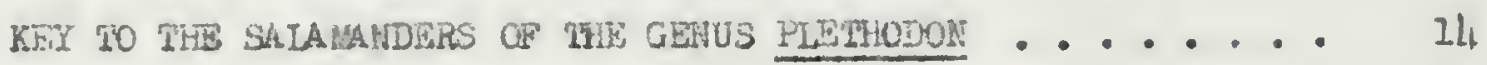

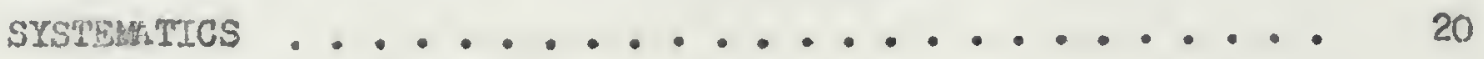

The Western Plethodons ................. 29

Plethodon vandykei Group ........... 3h

Plethodon vandykei vandykei Van Denburgh ... 35

Elethodon vandyke1 idahoensis Slater and Slipp . . 37

Plethodon vandykei larselli Burns ...... 37

Pethodon vehiculum Group .............. 38

Plethodon dunni Bishop .............. 38

Plethadon vehiculun (Cooper) ........ 41

Plethodon productus Group ........... 43

Plethodon productus, new name ........ 43

Plethodon neomexicanus Group ............. 46

Plethodon neomerdcanus Stebbins and Riemer ... 46

The Eastern Small Plethodons .............. 4 7

Plothodon melleri. Group ........... 51

Flethodon wellerl Valker ......... 51

Bothodon xichmondj. richmondi letting aud hittleran 61

Plethodon richrnondi popei Highton ard Circbrian . . 62

Plethodon Flchmondt nettingt Green ...... 64 
Plethodon cinereus Group ...........

Plethodon dorralis dorsalis Cope ...... 68

Plethodon dorsalis angusticlavius Grobman .... 71

P1ethodon cinereus cinereus (Green) ..... 76

Plethodon cinereus serratus Grobran ...... 78

Plethodon cinereus polycentratus Highton and Grobman 79

The Eastern Large Plethodons ........... 80

Plethodon vehrle1 Group ........... 90

Plethodon wehrlei wehrlei Fowler and Dunn .... 93

Plethodon rehrlei dix Pope and Fowler .... 9 96

Plethodon wehrlel jacksoni Neman .......996

Plethodon yonahlossee Group ......... 97

Plethodon zonahlossee Dunn ........ 100

Plethodon ouachitae Dunn and Hednze ...... 103

Plethodon caddoensis Pope and Pope ...... 105

Plothodon glutinosus Group .......... 106

Plethocion jordant jordani Blatchley ...... 129

Plethodon jordani metcalfi Brimley ...... 132

Plethodon jordani shermani stejneger ..... 134

Plethodon jordant unicoi, new subspecies ... 135

Plethodon Jordni melaventris Pope and Hairston - 136

Plethodon Jordani rabunensis Pope and Hairston - 138

Plethodon jordani teyahalee Fairston ..... 140

Plethodon jordani clemsonae Brimley ....... Ilil

Plothodon glutinosus glutinosus (Green) .... 193

Plothodon glutinosus albagula Grobman ..... 196

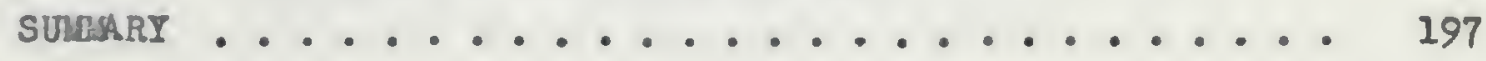

LITERATURE CITED ......................... 198 
IIST OF FIGURFS

Eigure

Page

1. Lateral and dorgal views of the trunk vertebrae of representatives of the three major groups of the genus Plethodon. . . . . . . . . . . . . .

2. Suggested phylogeny of the major subdivisions of the

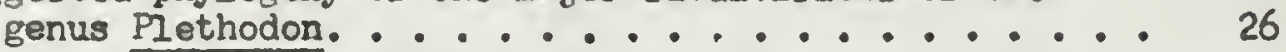

3. Suggested phylogeny of the Viestam Plethodons . . . . . 33

4. The distribution of the subspecies of Plethodon vandyke1 in Washington, Oregon, and Idaho. . . . 36

5. The distribution of Plethodon dunni in Oregon and southwestern Washington, ...................... 40

6. The distribution of Plethodon vehiculum in Oregon, washington, and British Columbia..........

7. The distribution of Plethodon productus in California and Oregon ... ..............

8. The distribuition of Plethodon neomexicanus in New

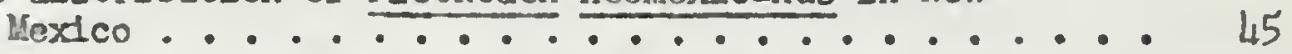

9. Suggested phylogeny of the Eastern Small Plethodons . . 52

10. The distribution of Plethodon welleri in North Carolina, Tennesse, and Virginia. . . . . . . . .

11. The distribution of the subspecies of Plethodon richmondi. . . . . . . . . . . . . . . . .

12. The distribution of the subspeciss of Plethodon dorsalis ........................

13. The distribution of the subspecies of Plethodon cinereus ........................

14. Vomerine teeth of 269 peninsula Florida P. glutinosus plotted against snout-vent length. . ........

15. Vomerine teeth of $45 \mathrm{P}$. glutinosus from the Coastal Plain of Virginia and North Carolina plotted against snout-vent length. . . . . . . . . . . .

16. Vomerine teeth of $115 \mathrm{P}$. j. jordani plotted against

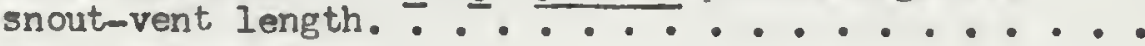


17. Vomerine teeth of $60 \mathrm{P}$. $\mathbf{w}$. wehrlel plotted against

18. Vomerine teeth of $39 \mathrm{P}$. caddoensis plotted against

19. Suggested phylogeny of the Eastern Large Plethodans... 85

20. Tho distribution of the subspecies of Plethodon wohrlei. 95

21. The distribution of the Plethodon yonahlossee Group . . 102

22. The distribution of the subspecies of Plethodon jordani . 112

23. The distribution of the dark-chinned (glutinosus) and light-chinned (albagula) populations of P. glutinosus in central Texas ..................

21. The distribution of Plethodon glutinosus in eastern 


\section{INTRODUCTION}

The North American genus Plethodon presently has more recognized forms than any other genus of salamanders. It is the type genus of the lungless family Plethodontldac, reviewed so ably by Dunn in 1926. At present, this is the most successful salamander farily; over half of the Iiving species of the Order Caudata are plethodontids. North America is the center of the distribution of the family, but one genus, Hydromantes, also occurs in Burope, and members of sevezal genera enter the Neotropical region. Salamanders of this family occupy habitats, ranging from strictly aquatic cavernicoles (Typhlomolge and Haideotriton) and mountain strean dwellers (Leurornathus) to others like Plethodon, which aro completely terrestrial, even to the extent of laying their eggs on Iand. Dunn believed that Plethodon is the most primitive genus in the attached-tongue branch of the fanily, and that Henldactylium, Ensatina, Batrachoseps, and Aneides are more specializod derivatives of a Plethodonlike ancestor.

In 1926, only eleven forms of Plethodon were knom to Dunn. In 1943, Bishop listed 17 species (one has since been removed fror the genus) and two subspecies (both are now considered different species). In 1944, Grobman reviewed the distribution and relationships of the eastern section of the genus, including some sixteen species and subspecies. There are now twenty-five forms recognized in eastern North America, with seven more in the western United States and Canada.

Grobman (19lu: 266) divided the eastern forms into two groups, the Large Plethodons and the Small Plethodons. He suggestod that these 
groups might actually represent distinct genera or subgenera, but he reserved judgement in this matter until the relationship of tho westem species with the eastem forms could be determined. One of the purposes of the present study is to deternine these relationships by a comparatlve study of the morpholory of all the species of the genus Plethodon.

of the trenty-five genera in the family Plethodontidae, only two others show as great or greater disjunctions in their distributions as that found in Plethodon. These are Hydromantes, with two forms in Europe and throe species in Califomia, and Aneides, with four species in western North America and one in the Appalachian Mountains of the eastem United States. In the past two decades, several new plethodons have been discovered in both eastern and westem North America. A review of the relationships of these forns offers a valuable opportunity to study the evolution of this important group of North American salamanders.

The Importance of examining plethodons in I1fe has been enphasized by most recent workers. Hany species, particularly the Large Eastern forms, are extromoly difficult to identify after years of preservation. In $f(m$ other vertebrates are differential characters betwoen species 30 rare. For this reison, a special attempt was mado to obtain living specimens of each form. Twenty-five of the thirty-two forms recognized herein have been studied allive.

The list of persons who have contributed specinens to this project is long and I wish to express to each of then ay sincerest thanks and appreciation for their valuable aid: Charles G. Adams, 
Walter Auffenberg, Ilerbert Barden, Albert P. Blair, E. E. Brown, Jerry and Esther Brown, Douglas H. Burns, Archie Carr, A. H. Chaney, Roger Conant, John W. Crenshaw, J. C. Dickinson, John Dolan, llemdon Dowling, Philip C. Dumas, Helen T. Gaige, H. Futh Gilreath, Arnold B. Grobnaan, T. P. Haines, Keith L. Hansen, Robert Hellman, Albert H. Highton, Thelma Howell, Leslie Lubricht, Robert Humphries, Richard M. Johnson, James Kezer, J. D. Kilby, James Knepton, H. D. Leake, Edwin E. NeConkey, John S. Hecham, Sherman A. Winton, Nilfred T. Neill, Howard T. Odum, Larry H. Ogren, David Pettus, John Quinby, Gecrge Rabb, Neil D. Richmond, Milliam Riemer, Bemard Zoseman, Doug Rossman, Albert Schwartz, Rowert S. Simnons, Ralph Sinclair, Willian Sloan, Peter Smith, Bette Stamer, Charles J. Stine, Fialter Stone, Virginia Switzer, Sam R. Telford, G. M. Thorp, Gordon Thurow, Don Tinkle, Amold and Fusty Van Pelt, Charles F. Walker, Wiliam Vitt, and Harry Yeatran.

Most of the material given me by these persons has been deposited in the University of Forida collection. Ihis collection has formed the nucleus of the material on which this study is based. Some additional spectmens have been borrowed from other collections, but I did not attempt to follow the course of the conventional monographer and examine every specimen available in museuns, simply for the sake of completeness. The matorial borrorred from other museums includes the following: Western Plethodons from the University of California; Texas $\underline{P}$. glutinosus from Bryce C. Brown, Ottys Sanders, John S. Mecham, and the Strecker luseun; $\underline{P}$. d. angusticlavius, $\underline{F}$. glutinosus, $\underline{P}$. ouachitae, and $\underline{P}$. caddoensis from the University of

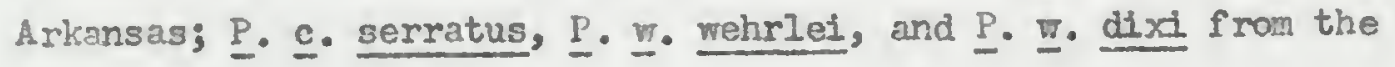




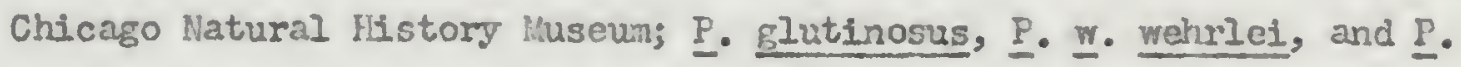
richmondi from the Carnegle lluseum; $\underline{P}$. cinercus from the Nuseun of Comparative Z00logy; P. richmondi from the United States llational Laseum; $\underline{P}$. Gutinosus and $\underline{P}$. 1. rabunensis from the Charleston livseum; $\underline{P}$ - dorsalis from the University of Coorcia; P. Mlchmondi and $\underline{P}$. Elutinosus from the Cincinnati Society of Natural History; $\underline{P}$. dorsalis from the Ross Allen-ilfred $T$. Neill collection; and the entire Plothodon collection of the Great Smoky Lountains National Park.

For the loan of material in thair care, I whish to thank the following museum officials: Nell D. Richrond, Camegie Luseum (Cli); Albert Schwartz, Charleston Museun (ChM); Robert Inger, Chicago Natural History Huseum (CNIiu); Ralph Dury, Cincinnati Society of Natural listory (CSNH); Arthur Stupka, Great Smoky Mountains National Park (GSiMP); Arthur Loveridge, Inuscum of Comparative Zoology (UCZ); hilfred T. Ieill, Ross AIIen Reptile Institute (ERA-MTN); Bryce C. Brown, Strecker líseum (SM); Ilerndon Dowling, University of Arkansas (UA); Bernard Martor, University of Georgia (UG); William liemer, University of Florida (UF); Charles F. Walker, University of kichigan, Luseum of $20010 \mathrm{gy}$ (Unsiz); and Doris M. Cochran, United States National Museun (USMM). The following individuals have generously lot me bomow material in thetr private collections: Bryce C. Brom (BCB); John S. Mecharn (JSM); and Ottys Sanders (OS).

In addition I have greatly berefltted from stimulating discussion of some of the problems which have arisen during the course of this study with the Pollowing persons: Drs. Robert Bader, Plerce Brodkorb, Archte Carr, John W. Crenshaw, J. C. Dicklnson, Richard A. 
Edwards, Coleman J. Goin, howard T. Odum, Nilliam Riener, H. K. Wallace, and Messrs. Walter Auffenberg, Robert Hellman, Rchard $M$ Johnson, and Tilfred T. Neill. iy wife, Anne, besides being patient and sympathetic wile undergoing considerable persomal inconvenience during many long hours of field work in the various hot, wet, cold, and mosquito-infested places where these animals live, has also matorially contributed to the project by typing, filing, proofreading, and especinlly by taling practicelly all the color notes on geographic variation of the $\underline{P}$. glutinosus group. The Chairman of ny Graduate Supervisory Cormittee, Dr. Arnold B. Grobman, has been a constant source of intellectual stimulation, encouragenent and holpful advice and criticism.

\section{METHODS}

The importance of studying living plethodons, because of the usual loss and alteration of their pigments in prescrvatives, has already been mentioned. It is almost impossible to study geographic variation in pigmentation without considerable field work, and it was initially hoped that this could bo done with all the forms in the genus. Unfortunately, several of the forms have not been seen alive and so our knowledge of their geographic variation has not been augnented. However, I have been able to do a consicierable amount of field work with some of the Eastern Large Plethodons, and the result has been a considerable arount of now inforation conceming them. I believe that when similar studies of other species are made, thay will be found to vary as much as glutinosus and jordani in pigmentation char acters. 
A perusal of the literature on this genus will disclose that most workers have given considerable weight to variation in the number of costal grooves. A careful study of the literature indicates, hovever, that there is not agreement in the reports of number of costal grooves in many species. The reason for this was apparent to the writer when I failed to obtain consistant counts on the same specimens counted at different times. A method for accurately dater mining the true variation in body segmentation would be a necessary preltminary to the use of this character in studying relationships. Since the costal grooves show a direct correlation with the number of vertebrae, a method of counting the number of trunk vertebrae by the use of I-ray photographs was devised. As an outgrowth of this study, a. method for counting costal grooves wisich will accurately reflect the body segmentation of salamanders of this genus will be reported below.

l'any other characters have been used in the study of the systematics of this genus. As far as possible, these have been restudied using much new material that has recently become available. Several nomenclatorlal changes will be suggested based on an attempt to best indicate the blological relationships of these organisms.

The results of this study have clearly indicated that there are three major natural subdivisions of the genus Plethodon. These would probably be considered subgenora in most animal groups, but herpatologists have raraly used subgenera in their classification. Although the use of subgenera would be helpful in this case, comnon names will be used for these groups in confornity with current herpetological practices. They $w 117$ be referred to as the "lestern Pleth- 
ocons," "Castern Small Plethodons," and "Eastern Large Flethodons." Lach of these subdivisions of the genus is further divided into species groups consisting of species which are more closely ralated to each other than thoy are to any other similar group. In a fer cases, species which are morphologically quite distinct from any other species In their section of the gomus have been segregated into a species group consisting of a single species.

For each taxon, information on the morphology, variation, and distribution is given, followed by a synonomy, data on the type specimen, diagnosis of the form, and a description of the pigmentation, segmentation, number of vomerine teeth, and size. Detailed descriptions of several hundred specimens were made during the course of this study. For most forms, similar data are available in Bishop (1943) or Stebbins (1951) or in the original description. It is unnessary to repeat these hore, since the concern is variation of populations, not detailed descriptions of individual specimens.

Dunn (1926) presents falrly complete synonomies for each of the forms known at that time. Therefore the large number of references on the distribution and habits of the more comnon forms are not included here. An attenpt has been made to include the first refer onco to each combination of names, as vell as most of the papers dealing - mith the systematics of each form. Check Iists have usually been omittod, except when now combinations of names or other now infomation is presented. Consistancy has not been a goal, and some papers dealing with habits or distribution have been included in the synonomies of little known species, whlle simllar papers on well known forms 
that do not contribute ner information have been omitted.

The locality maps have been preparod mainly as an aid to the discussion of the distribution of the varlous species groups. They are based on Iiterature records as well as specimens examined by the writer. Naps showing the distribution of many of these forms are avallable elsewhere, but there have been many changes in the taxonomy since the publication of some of these, and it seems desin able to include them here in spite of the fact that there is some repetition. New information on the geographic distribution of several of the forms is included on some of the maps.

Seventeen subspecies are recognized in this paper. An examination of the distribution maps indicates that several of the polytypic species exhibit terminal raciation and most of these races are isolated from their nearest relatives by areas of uninhabited country. This is true of the races of $\underline{P}$. vandykei, $\underline{P}$. dorsalis, $\underline{P}$. cinereus, and to some extent, P. glutinosus. The subspecles of $\underline{P}$. wehrlel are poorly defined, and need more study. There do not appear to be natural barriers between some of the subspecies of $\underline{P}$. Flchmondi and $\underline{P}$. Jordant, and there is evidence that internediate populations are present betreen some of the races. A more detailed consideration of raciation in both of these specios is given below.

THE REIATION BETWEEN NUMBER OF COSTAL GROOVES AND TRUNK VFRTEBRAE IN PLETHODON

Radiographs of serles of spectmens of all the species in this genus have indicated that the number of trunk. vertebrae in a 
single population is remarkably constant. (Since there is little differentiation of the salanander body vertebrae into regions, Francis (1934) suggests that all precidudal vertebrae, except the atlas and the sacrum, be called trunk vertebrae.) There is never a variation of rore than three trunk vertebrae in a single population and with few exceptions, the intermediate figure has a very high frequency of occurrence. The value of this character in studying variation becomes apparent when it is found that a difference of a single vertebra between two populations is easily detectable and has been used suscessfully as a key character to separate a high proportion of specimens of two contrasted forms.

A nethod of counting costal grooves that would accurately reflect the number of trunk vertebrae would be much more effective in the taxononic study of this genus. At present, their use is rather limited, since they are rarely counted consistantly by different workers. Pope (1950: 102) correctly sumarizes the existing situation by stating that "variation of a magnitude of one or two grooves will be meaningless unless the same worker has made all the counts and done so r.ith great care." The method described here has been found to correctly correspond with the number of trunk vertebrae with over 90\% accuracy.

The atlas is not related to any costal grooves. The first trunk vertebra is located just anterior to the gular fold and its rib does not appear to be associated with the gular fold or with any of the costal grooves. The rib of the second trunk vertebra is located in the ryoseptun of the first costal groove. The external position of this groove varies somemhat, but is usually close to the front 
limb insertion. If the first costal groove is poorly defined or absent, as often occurs when it is located directly over the front limb inser tion, it should be counted, as the space obviously corresponds to a vertebra wither the groove is visible or not. The individual variation in the position of the first costal groove is probably due to the variation in the position of the pectoral girdle relative to the vertebrae. The girdle may be located opposite the second trunk vertebra, between the second and third trunk vertebrae, or opposite the third trunk vertebra. The ribs of the third trunk vertebra extend posteriorly so that the second costal groove is always posterior to the front limbs.

There is a one-ta-one relation between the remaining body vertebrae and the costal grooves, except in the case of rare aberrations (one vertebra possessing two or more pairs of ribs, or one vertebra possessing a rib on only one side, in which case a corresponding costal groove is present only on that side). The last pre-sacral vertebra (usually the only trunk vertebra which does not possess ribs) is repro sented by the groove just anterior to the insertion of the hind limbs. often this groove joins ventrally the one just preceeding it so that on the lower sides there is only onegroove which is forked dorsally. Both grooves should be counted, since they correspond to tro separate vortebrae. The groove present over the hind limb insertion (sometimes weakly developed or absent) corresponds to the sacral vertebra, and each groove on the tail corresponds to a caudal vertebra.

There is much more individual variation in the position of the sacral vertebra in relation to the pelvic girdle than there is in the relation of the shoulder girdle to the second and third trunk vertebrao. 
The sacral vertebra may be located so far anterior to the pelvic girdle that the first caudal vertebra is opposite the hind Iimbs. It may also be slightly anterior, oppostte, or sifghtly posterior to the pelvic girdie. Occasionally when it is posterior to the glrdie, the costal groove corresponding to the last trunk vertebra is located over the hind limb. This is the major source of error in attempting to accurately correlate the number of costal grooves with the number of trunk vertebrae. Fortunately, however, fowcr than $20 \%$ of the specimens examined were in this category. Using this method, costal groove counts were made on 85 specimens of several species of the genus Plethodon (includIng specimens possessing 15 to 22 trunk vertebrae), and $93 \%$ of the counts accurately represented the number of trunk vertebrae obtained from X-ray photographs. Since the first trunk vertebra is not assoclated with a costal groove, the number of costal grooves is always one less than the number of trunk vertebrae. It would therefore appear that this method can be used advantageously to obtain an accurate estimate of the number of trunk vertebrae of all the species of the genus Plethodon.

Occasionally the sacral rib mey attach to one vertebra on one side of the animal and to the folloming vertebra on the other side. Rarely, there aro two Eacral ribs issuing from two successive vertebrae on the same side of the animal. The suggested method of counting costal grooves is of no value in detecting such abnornalities. 


\section{PIGLENTATION IN THE GENUS PLETHODON}

Figmentation in living specimens was studied with the aid of a dissecting microscope. Although there is great variety in the coloration of the animals included in this genus, the actual different types of pigments are few. No histological or biocheraical studies of the pigments have been made, thus similarity in the appearance of the pigmentation is the basis for the above statement. Three main types ware identified and are called melanophores, guanophores, and lipophores, following stebbins (1951).

Melanophores are present in all the forms in the genus. They are responsible for the dark ground color of these sal ananders. The other plgments generally occur in gaps in the melanophore ground color.

Guanophores are responsible for the white and brassy spots, present on many of the species. There appears to be little difference in the structure of the different colored guanophores, but mainly a difference in the amount and color of light reflected from the spoto. The iridescence characteristic of animals with "brassy" "dorsal spots appears to be centered in small round crystalline structures found at intervals along the pseudopodia of the guanophores. The number of these crystals seens to determine the amount of the iridescence that has been variously described by different workers as "brassy flecking," metallic golden spotting," "golden blotches," "bronzy mottling," and "frosting." This type of guanophore pigmentation is present in the iris of most of the Eastern Small Plethodons and the Western Plethodons, and is present on the dorsum of many of the spectes. It is responsible for the brassy dorsal flecks of glutinosus, ouachitae, dixi, clemsonae, popei, nettingt, 
cinereus, polycentratus, dorsalis, velleri, and vehiculum. In welleri, these guanophores are concentrated to form dense clusters. In glutinosus, they are usually associated with other mite guancphores. In the other forms they are scattered over the back and are not clumped into spots. Brassy flecks are rarely found other than in the iris or on the dorsum of salamanders of this genus.

Guanophores that lack the brassy iridescence are common on the belly and sides of many spocies, and are also present on the corsum, occasionally occurring there with the brassy type. They have a much Ereater tendency to be clumped together to form larger spots than do the brassy flecks, but are occasionally found singly. In glutinosus, for example, it is often possible to see, on the same animal, every type of internediate between the brassy tyoe and those which lack the brassy iridescence.

The white guenophores are characteristically found on the dorsua of glutinosus, onachitae, cinereus, polycentratus, popei, dorsalis, and vehiculum. They are present on the sides of almost all of the eastern species (except metcalfi and melaventris), and on the bellies of all the Fastern Small PIethodons. Often these lateral and ventral spots have a yellowish color, but this is not due to the presence of brassy mlecks.

Hpophores do not have the structure of guanophores in that they lack the pseudopodia wich can easily be observed in the guanophores. The red color of jordani, shermani, wehrlei, yonahlossee, ouachitae, cinereus, polycentratus, serratus, dorsalis, and vehiculum 
appears to be due to the same type of lipophore pigment. The dorsal band of yonahlossee is a darker color because of the additional presence of melanophore pigment. Lipophores may also be yellow in color, as in some cinereus, vehiculum, and cunnt.

The variety of colors present in the genus scens to be due entirely to variation in the abundance of these pigments or varlous combinations of the three. In some forns, the lipophoros or guanophores or both are lacking. There is also variation in the concentration of melanophores. These pigmentation characters may vary somewhat within 2 species, both individualiy and geographically, but are fairly uniform in most forms, enabling a person familiar with living specinans to casily identify most salamanders by the color pattern alone. The phylogenetic significance of the distribution of these pigments in the varlous plethodons is discussed below in the accounts of the vartous forias.

KEY TO THE SALAYAIDERS OF THE GENUS PLFTHODON

The kcy is based mainly on the average number of trunl vertebrae occurring in each of the forms. Before using this key, it is suggested that the section on the method of counting costal grooves that accurately reflects the number of trunk vertebrae be read. A small per centage of specimens of each form may not be correctly identified on this basis, but a small series will usually key out corrcetly. Ranges are Included and locality data may proove more helpful in identifying preserved specinens than pigmentation characters.

1 a Costal grooves usually ll ................... 2

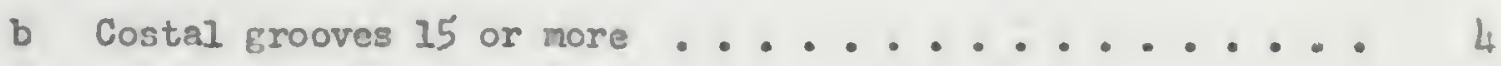


2 a Ventral color reddish (Mluztnomah County, Oregon, and Skam mania County, Washington) ........

b Ventral color not rendish ............. 3

3 a " Yellow or orange dorsel stripe contrasts sharply with the lateral black ground color; the proxinal segments of the limbs dark in color (Kootenai County, Idaho) P. I. idahoengis b Ground color light, not contresting sharply with the dor sal stripe; yellow lipophore pigment similar to that found on the dorsum present on the proximal segment of the Iimbs (restern Washington) ....... $\underline{P}_{-} \underline{\text { v }}$ vandykei 4 a Costal grooves usualiy 15 (western Oregon and southwestern

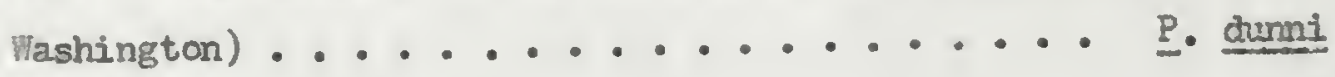

b Costal grooves 26 or more ................... 5

5 a Costal grooves usually $16 \ldots \ldots 6$

b Costal grooves 17 or rore .................. 20

6 a Belly mottled rith yellow or red, white and black; size small, usually under $50 \mathrm{ram}$. snout-vent length; often a red, tan, or yellow dorsal stripe (southwestern British Columbia, ineluding Vencouver Island, westem Washington and western

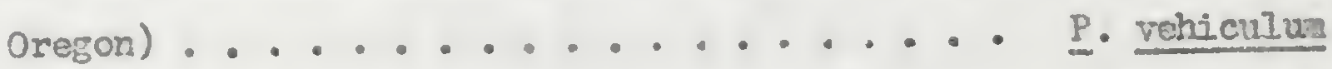

b Belly usually dark, at least posteriorly, or with seattered small white ventral spots; size usually larger (except welleri and caddoensis); dorsai stripe usuaily absent (except पonahlossce and ouachitae) (eastern United States) ?

7 a Red picment present on back, legs, or chieeks ....... 8

b No red pigment present on animal ........... II 
8 a Red pigment confined to sidies of head or legs in adurts. 9

b Red pigrent largely restricted to dorsum ........ 10

9 a Red pigment most abundant on sides of head (Groat Smoky

Mountains of Tennessee and North Carolina) . P P j jordani

b Red pigment most abundant on legs (Nantahala Hountains,

North Carolina) ............ P. I. shernanl

10 a Wite pigment lacking in dorsal stripe (Blue Ridge kpun-

tains of southrestern Virginia, northeasterm Tennessee,

and northwestern North Carolina) ..... P. Yonahlossee

b Abundant white pigment occurring within the dorsal stripe

(Ouachita Iountains of Arkansas and Oklahona) - P. Ouschitae

11 a Size small, adults not over 50 . snout-vent length;

back with large coalescing 1ridescent brassy spots,

usually covering about half the area of the dorsur

(Blue Pidge Province of southwestern Virginia, north-

eastern Tennessec and northwestem liorth Carolina) $\underline{P}$. wallerl

b Back without dorsal brassy spots, or if present, they

are small in size and cover less than one quarter of

the area of the dorsum ................. 12

12 a Body entiraly black, guanophores and lipophores absent . . 13

b Dorsum and/or sides wth guanophore spotting ...... 14

13 a Belly much lighter than dorsun (mountains of western North

Carolina and adjacent Tennessee and Virginia) P. j. metcalri

b Belly almost as dark as dorsum (southwestern North

Carolina)............ I. melavantris 
If a Back with large conspicuous white or brassy dorsal spots.

b Back without large consplcuous guanophore spotting, or if present, the spots are of very srall size.......

15 a lielanophore pignentation on chin greatly reduced, compared to belly ......................

b Melanophore pigmentation on chin similar to that on belly

(eastern United States from southerm New York to northern

Florida, west to eastern Loulsiana, Illinois, Missourl, easterm OKlahoma, and the Balcones Escarpment in iexas)

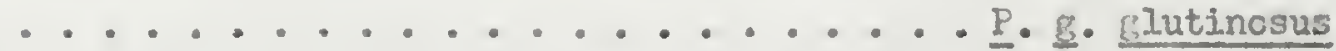

16 a Dorsum with wite spots only (Bulcones Escarpuent in

east central Texas) .......... P. g. albagula

b Dorsum with large white spots and smaller brassy rlecks

(Caddo kountains of Arkansas) ....... P. caddoensis

17 a Dorsum with very small wite or brassy spots ...... . 18

b Dorsum black, without any guanophore spotting . . . . . 19

18 a Dorsum covered with tiny brassy flecks (vicinity of

Jocassee, South Carolina) ......... P. 1. clamsonae

b Dorsurn with very tiny scattered wite spots (Tusquitee

and Snowbird Mountains of western North Carolina)

..................... P. teyahalee

19 a Belly much Ilghter than ground color of back (Unicoi

liountains of western North Carolina and eastern

Tennessee) ................ P. j. unicoi

b Belly nearly as dark as dorsal ground color (mountains

of northeastem Georgia ........ P. . . rabunensis 
20 a Costal grooves usually $17 \ldots \ldots . . . \ldots$

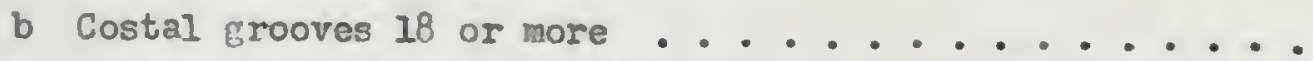

21 a Large red spots on dorsun of adult (southwestern Virginia)

P.

b Red spots absent from dorsum of adult ........ 22

22 a Dorsum with numerous white and brassy spots (Roanoke

County, Virginia) ........... P.

b Dorsum with very small white or brassy spots (Cattaraugus

County, New York, south through western Pennsylvania,

adjacent Ohio, anỏ Vest Virginia) ..... P. w. wehrlei

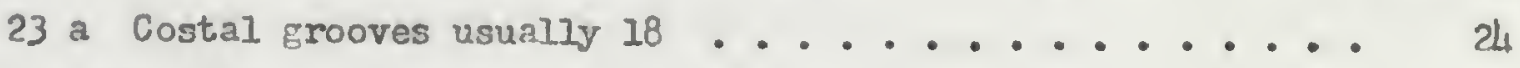

b Costal grooves 19 or more .............. 27

24 a Size large, up to $66 \mathrm{~mm}$. snout-vent length (northwestern

Califomia and southwestem oregon)..... P. productus

b Size small, up to $45 \mathrm{~mm}$. in snout-vent length (eastem

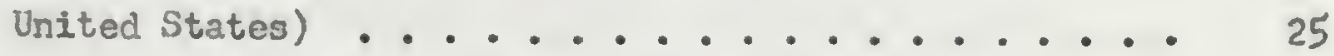

25 a Belly mottled with red, yellow, white, and black pigment . 26

b Belly black, with small white spots (Cheat ilountains of

West Virginia) .............

26 a Dorsal stripe very narrow, less than $1 / 3$ the width of the body (southwestem Missouri, northwestern Arkansas, and

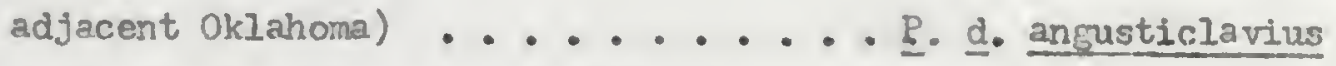

b Dorsal stripe much wider than $1 / 2$ the widh of the body,

edges of stripe very irregular (southern Illinois, Indiana, and southem Ohio, south through Kentucky and Tennessce to northern $\Lambda$ labama and northwostern Georgia) . $\underline{P} \cdot \underline{\text { d. dorsalis }}$ 
27 a Costel rooves usually $19 \ldots \ldots$

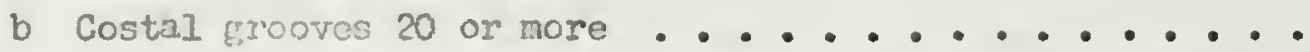

28 a Fifth tre on hind foot usually with one phalonx (Jemez

lountains of llow lexico) ....... P. neomexicanus

b Fifth toe on hind foot with two phalanges (easterm North

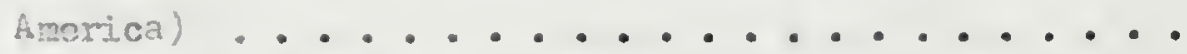

29 a Dorsal ref stripe with straight edges (southem Canada, scuth to worth Carolina, eastern Kentucly, southern IIInnois, and eastem Uissouri) ..... …

b Dorsal rel stripe with serrations corresponding to each costal groove (western irlansas and eastern Oklam homa )................. … serratus 30 a Ror pirment present on sides and dorsum (northwestern

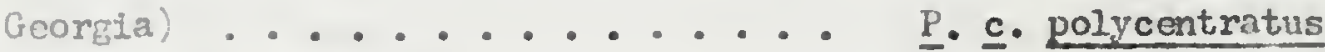

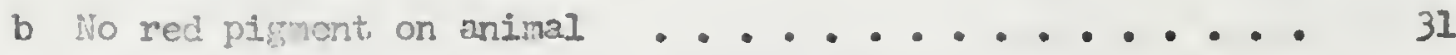
31 a Costal Erooves usually 21 or more (westem Pennsylvania, southom Ohio, eastorn Kentucky, south to northwestern Virginia) ..........

b Costal grooves usually 20 (southwestem Virginia, northwestem lorth Carolina, and adjacent Kentucky) - $\underline{P} \cdot \underline{r} \cdot$ popei 


\section{SYSTEMATICS}

\section{Plethodon Tschudi}

Plethodon Tschudi (1838:58). Genotype (by original designation): Salamandra glutinosa Green.

Phatnomatorina Bibron in Bonaparte (1839). (Substitute name) Sauropsis Fitzinger (1843: 33). (non Sauropsis Agassiz, 1832, Jahrb. Min., 3: 142). Genotype (by original designation): Salamandra erythronota Green.

Diagnosis:- Plethodortidae with tongue attached in front; premaxillae separate; teeth on posterior portion of maxillae; tail not constricted at base; five toes on the hind feet; no palmar tubercles; terninal phalanges normal; and no aquatic larval stage.

According to Dunn (1926), the closest relatives of Plethodon are Batrachoseps, Ensatina, Aneides, and Hemidactylium. All four of these genera differ from Plethodon in several fundemental characteristics. Batrachoseps and Hemidactylium possess only four toes on the hind feet. Ensatina and Homidactylium possess a basal constriction of the tail. Ensatina has palmar tubercles. The preavillae are fused in Aneides and Batrachoscps (except B. Wrichti). Hemidactylium has an aquatic larval stage. Aneides lacks tecth on the posterior portion of the maxilla and has expanded terinal phalanges. Dunn (1926: 22) believed that Plethodon is the most primitive genus in this group of genera and that the others, with the possible exception of Ensatina, are more specialized than Flethodon. The genus Plethodon is the largest in number of species, and there is more divergence vithin the genus than in the other related genera. This might be considered evidence for, but not necessarliy proof of, a greater age for this genus. 
Grobman (1044: 266) suggests that the relationship between the Eastern Lirge and Snall Methodons is not close and lists size and costal groovo sifferences wich distinguish then. Actually there is some overlap boticen the Eastern Large and Small Pethodons in these charictors, kixt thore are other important differences between the two groups. "the mental gland is mach better developed in male Eestem Large Plethodons thon in the Eastem Swell Plethodons. The worm-like body and shorter lezs of the lastern Snall Plethodons is characteristic. The histern 3 mall lethodons heve fewer teeth and there is a groat deal of variation in the number of trunk vertebrac within the group (range 16-24), here:s the Lastern Large Flethodons show very little variation (range 16-19). "Where is more vebbing on the toes of the small forms than in the large spocies. The Eastem Large Flethodons have an unpigmented parietal yeritoneum, wile in the small species the peritonoum is piomentco "ith melanophores. The difrerences in the stmcture of the vertebrac are discussed below.

One species, P. wehrlei, is usually included with the Eastem Large lethodons on the basis of size, but in several ways it is interm mediate betweon the two groups. It has more costal grooves and fewer teeth than other bastern Large Plethodons. Its toes are webbed as in the instem small Plethodons and the peritoneum has a few melanophores. Nere it not for the intermediato charecter of this species, the two groups should probably be recognized as distinct genera, but the somewhat inter. ejiate nature of mehrlei would seen to indicate that they have not tocone sufficiently distinct to fustify such an action. The two groups could best be ragarded as subgenera, but to conform vith current prectise, the comon names, Erstem Large Plethodons and Eastem 
Small Plethodons, will be used in this paper. Although P. wehrlei possesses more characters that would link it with the Eastern Small Plethodons than do any of the other Eastem Large Plethodons, it is probably more closely related to mombers of the lattcr group. Therefore, it is included as a separate species group under the Eastern Large I Iethodons. Its intermediate position is imuortant, however, in linking the two groups.

During studies on the osteology of this genus, certain difforences in the vertebrae of the two eastern sections of the genus have been noted. The height of the vertebrae of the Eastern Small Plethodons is proportionately less and the vertebrae usually lack the neural spines that are present on those of the large eastern species (see figure 1). $\underline{P}$. whrlel is not intemodiate in this regard, but closely resembles the other Eastem Large Plethodons. The vertebras of all the eastem species have been examined except for caddoensis and michmondi.

To investigate the relationshlp of the western forms with those in eastern North America, each of the above differential charactors was studied in all five of the western species. As with the eastern forms, the size varies within the group, but four of the five western species are as large as most of the Eastern Large Plethodons. The number of trunk vertebrae varies considerably in the vestern forms (range 15-20). The mental gland is poorly developed in all the Festern Plethodons. The body form is variable, ranging from short and stout in vandyke1 to very elongate in neomexicanus. The number of vomerine teeth is low in the western forms. The toes of two species (dunni and veht- 

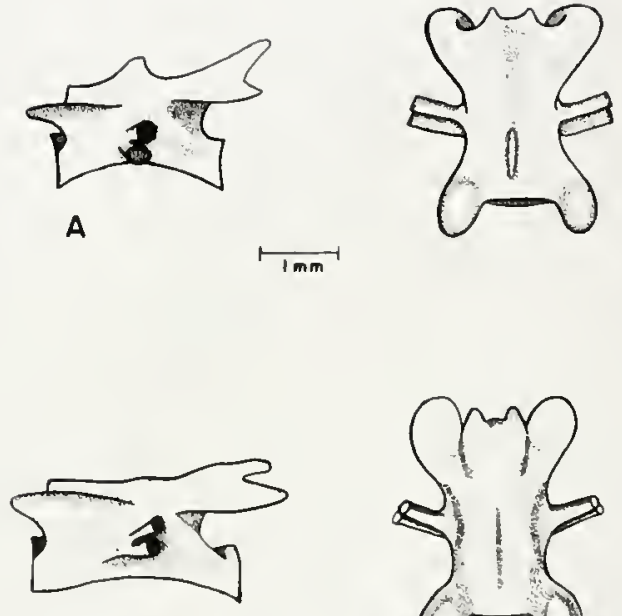

B
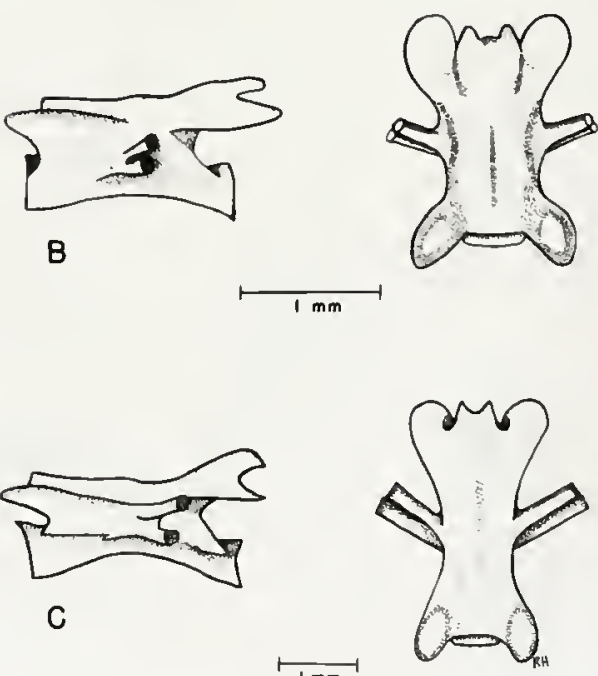

Figure 1. Lateral and dorsal viems of the trunk vertebrae of representatives of the three major groups of the genus Plethodon. A. P. glutinosus. B. P. welleri C. P. dunni. 
culum) are ver. slibhtly irebbed, wile the other chree spocies have webbed tocs. 2l.s peritoncun of all of the iestem jethodons is pigmented vith nelinophores. The vertebrac of the viestern forms are quite different from both eastern types (‥ neomexicanus has not been examined). ther are proportionately longer and have Ionger transverse processes than any of the eastem species. As a group, the Westorn Plethoions arc more variable, and in at least one character, the structure of the vertebrie, they are very distinct from both enstern sections of the gonus. It would appear that the vestern and Eastern Plethodons have been separated for a long time, anc that both have undergono considerable speciation during this period.

In several ways, the Fastern Small Plethodons resemble the Westem Flethodons more closely than do the Eastern Large Plethodons. The red or yellow dorsal stripe is more comon in both groups than it is in the Hasterm large Plethodons. Both have a great amount of variation in the number of tmank vertebrae and degree of elongation of the body. Loth have low ronerine teeth counts and a pigmented peritoneum. Both hrve a less well developed mental gland than the Kasterm Large Plethodons (except for dorsalis). It $r$ culd appear that the Eastern barre 1 lethodons are the more specialized forms, with a Inrgar number of vomerine teoth, loss of pignontation in the peritoneun, and incrcaso in the development of the mental gland. The fact that $\underline{F}$. wehrlei possesses characteristics of both groups would indicate that both vere derived froin a comon ancestor. This comnon ancestor was probably more like the Eastern Small Plethodons and the Western Plethadons in most of its characteristics, since it would be unlikely that these two groups would have indepondently converged toward each other 
in so many ways from an ancestor that whs siniler to the Eastern Large Plethodons as suggested by Dunn. The relationships of the three groups would appear to be best indicated by a phylogeny similar to that show in figure 2.

The relationship of the Western Plethodons with the other plethodontid genera in western North America needs further study. It may be that the Western Plethodons are more closely related to Batrachoseps, Insatina, or western Anoides than they are to any of the Bastern Plethodons. The western plethodontid salamanders may have been isolated from their eastem relatives for a long period of time. The fact that two groups now included in the genus plethodon, one in eastem North America and the other in the western part of the continent, have both retained many primitive characteristics, doos not necessarlly mean that they are still generlcally related to one another. The fact that each of these groups (the Western and Bastern Plethodons) has more species than any other plethodontid genus in its region, as well as the the filct that these species are so diverse, would suppot the view that they have been separated for a long period of time. A reviaw of this entire problem is needed, but it would involve an investigation of the characteristics of the genera Aneides, Batrachoseps, insatina, and llemdactylium, and is beyond the scope of this study. Such an inquiry should be corpleted before erecting a new genus for the Western Plothodons, but this arrangement seems to be indicated by the present incomplete information.

The systeratic arrangement of the genus plethodon suggested in this paper is as follows: 


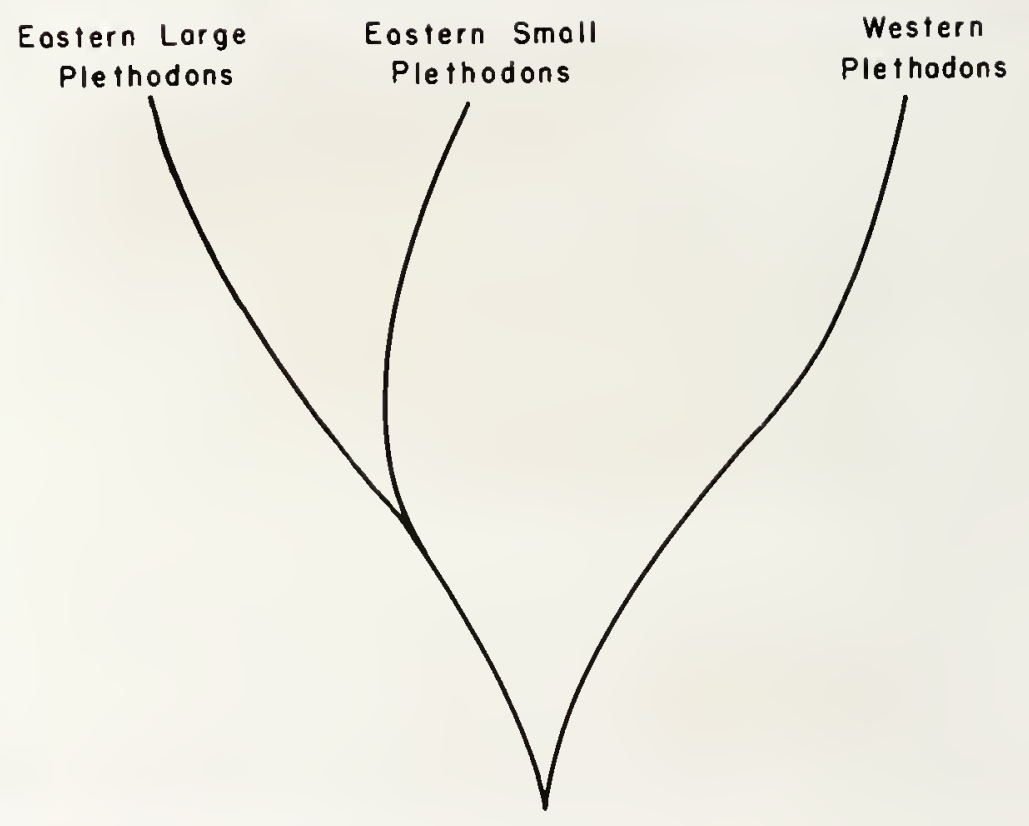

Figure 2. Suggested phylogeny of the major subdivisions of the genus Plethodon. 
Western Plethodons

Plethodon vandykei Group

Plethodon vandykei vandykei Van Denburgh

Plethodon vandykel idahoensis Slater and Slipp

Plethorion vandykei larselli Bums

Plethodon vehiculum Group

Plethodon dunni Bishop

Plethoton vehiculum (Cooper)

Plethodon productus Group

Plothoion productus new name

Plethodon neomexicnnus Group

Plethodon neomexicanus Stebbins and Riemer

Eastern Small Plethoions

Plethorion wellexi Group

Plethodon welleri alker

Plethodon richmondi richmondi Hetting and liittlemen

Plethodion richmondi popei Highton and Grotmen

Plethodon richmonds nettingi Green

Plethoion cinereus Group

Plethodon dorsalis dorsalis Cope

Plethodon dorsalis angusticlavius Grobran

Plethodon cinereus cinereus (Green)

Plethodon cinereus serratus Grobman

Plethodon cinereus polycentratus lighton and Grobman 
Eastern Large Plethodons

Plethodon wehrlei Group

Ilethodon wehrlei wehrlei Fowler and Dunn

Plethoton wehrlei dixi Pope and Fovler

Plethodon wehrlei jacksoni Newman

Plethodion yonahlossee Group

Plethodon yonahlossee Dunn

Pethodon ouachitae Dunn and lleinze

Plethodon caddoensis Pope and Pope

Plethoion glutinosus Group

Plethodon jordani jordani Blatchley

Plethodon jordani metcalfi Brimley

I Iethodon jordani shermani Stejneger

Plethodon jordeni unicoi new subspecies

Iethodon jordani melaventris Pope and Hairston

Plethodon jordani rabunensis Pope and llariston

Plethodon jordani teyahialee Halrston

Plethodon jondani clensonae Brimley

Iethadon glutinosus glutinosus (Green)

Plethodon Rlutinosus albagula Grobman 
The Western Plethodons

The Westem Plethodons include five species, none of which, except for dunni and vehiculum, appear to havo close affinities. vandykei, with three presently recognized subspecies, vandykei, larsclli, and Idahoensis, occurs in coastal Visshington, northwesterm orcgon, and northern Idaho. P. dunni is know from southwestem Washington and coastal Oregon. P. vehiculum ranges on the coast from central Oregon to southern British Columbia, including Vancouver Island. P. productus (formerly . clongatus) occurs in a small arae in northwestern Callfornia and southwestem Oregon. P. neomexicanus is know only from the Jemez Mountains of New Kexico.

Stebbins (1951) has recently summarized the lnowledge of the amphibians of western North America, and has given detailed descriptions of all five species in life. Little new information on individual or geographic variation can bo offered hore since I have had no ficld experience with these animals and only four forms (1dahoonsis, dunni, vehiculum, and productus) have been oxaminod in life. Keference should be made to Stebbins' book for further information on these forms.

Radiographs of a series of cach of the forms (exccpt the recently described P. I. Iarselli) were taken and the number of trunk vertebrae in each form is shown in table I. The usual number of trunk vertebrae in each specles of lestern Plethodon is differcnt, and nono of the known forms possess 18 trunk vertebrae as the nodal number.

Except for vehloulum, 211 of the Westcrn Plethodons are fairly large in size. All but neomexicanus possess a stripe phase in the adult, and all but dunni and vohiculum have wobled toes. The vomerine tooth 
TABLE I

THE NULBER OF TRUNK VERTEBPAE IN HESTERN FORIS OF THE GHUS PEETHODUN

\begin{tabular}{|c|c|c|c|c|c|c|}
\hline \multirow{2}{*}{ Form } & \multirow[b]{2}{*}{15} & \multicolumn{4}{|c|}{ Number of trunk vertebrae } & \multirow[b]{2}{*}{20} \\
\hline & & 16 & 17 & 18 & 19 & \\
\hline P. V. vandykei & 3 & & & & & \\
\hline$\underline{P} \cdot \underline{\mathrm{v}}$ idahoensis & 11 & 4 & & & & \\
\hline P. dunni & & 27 & 1 & & & \\
\hline P. vahiculum & & 10 & 32 & 7 & & \\
\hline P. productus & & & & 1 & 15 & 2 \\
\hline P. nocmexicenus & & & & & & 7 \\
\hline
\end{tabular}


counts of all of the western forins are low compared to lastern Large Plethodons of sivilar size; vehiculum and productus have especially low vomerine counts.

P. vandykel is unusual in possessing a parotid gland and in having the lowest number of vertebra in the genus. P. neomexicanus is unusual in being the only species in the genus that has a reduced fifth toe on the hind limbs.

Plethodon dunni and Plethodon vehiculum appear to bo rather closcly related. P. dunni attains a larger size than P. vehiculum and has more vomerine toeth. $P$. vehiculum usually has one more trunk ver tebra than dunni. P. dunni has nore aquatic habits than vehiculum. The color of the dorsal lipophores in the striped phase of the two foms is different. The stripe of dunni is usually greenish yellow, whilo that of vehiculum varies from reddish tan to yellow. The toes are very slightly wobbed in both and most othor structural features are similar.

The other Westem Plethodans possess a considerable amount of webbing on their toes. The amount of webbing on the toes does not appear to be correlated with aquatic tondencies, since the two most aquam tic foms, dunni and vandykei, represent extrenos in the absence and presence of webbing in the western forms. The forns vehiculum and productus, both with more terrestrial tendencies, also differ greatly in anount of webbing between the toes. Horeover, in the eastern United States, sone of the forms have webbed toes, while others do not, yet all are terrestrial.

There is no doubt that dunni and vehiculun should be regarded 
as distinct species, since tho two occur sympatrically through most of the range of dunni without eny evidence of interbreeding. A study of this relationship and the possible differences in the habitat niches of the two forms, suggested by Stebbins (1951: 65), 1s much to be desired.

The forms, vandykei, productus, and neomexicanus all seem to differ from each other as much or more than species groups in the Eastern Plethodons. The fact that they are so distinct morphologically makes it difficult to determine-their relationships. In all probability, these forms have been differentiating for a long period of time. There has probably been a considerable amount of extinction of humid forest dvelling western "Jorth American amphibians due to climatic changes which have occurred during or since the Tertiary. The present discontinuous distribution of this genus in the area, vith only two species recorded in the Rocky Nountains, separated by almost a thousand miles, supports this view. Without doubt there are probably other undiscovered forms of this genus in the vestern United States. Ilany salamanders of the region are diflicult to collect, except during extremely favorable conditions, and some may have been overlooked in spite of intensive collecting. There remain many areas in which there has been very little collecting, and these may be profitebly searched for members of this genus. Lowe (1955: 250), for expmple, believes that plethodontid salamanders will be found in the higher mountaing of Arizona because conditions there are similar to those where they have been taken in other aroas.

The relationships of these salamanders would seem to be best indicated by the phylogeny shown in figure 3. 


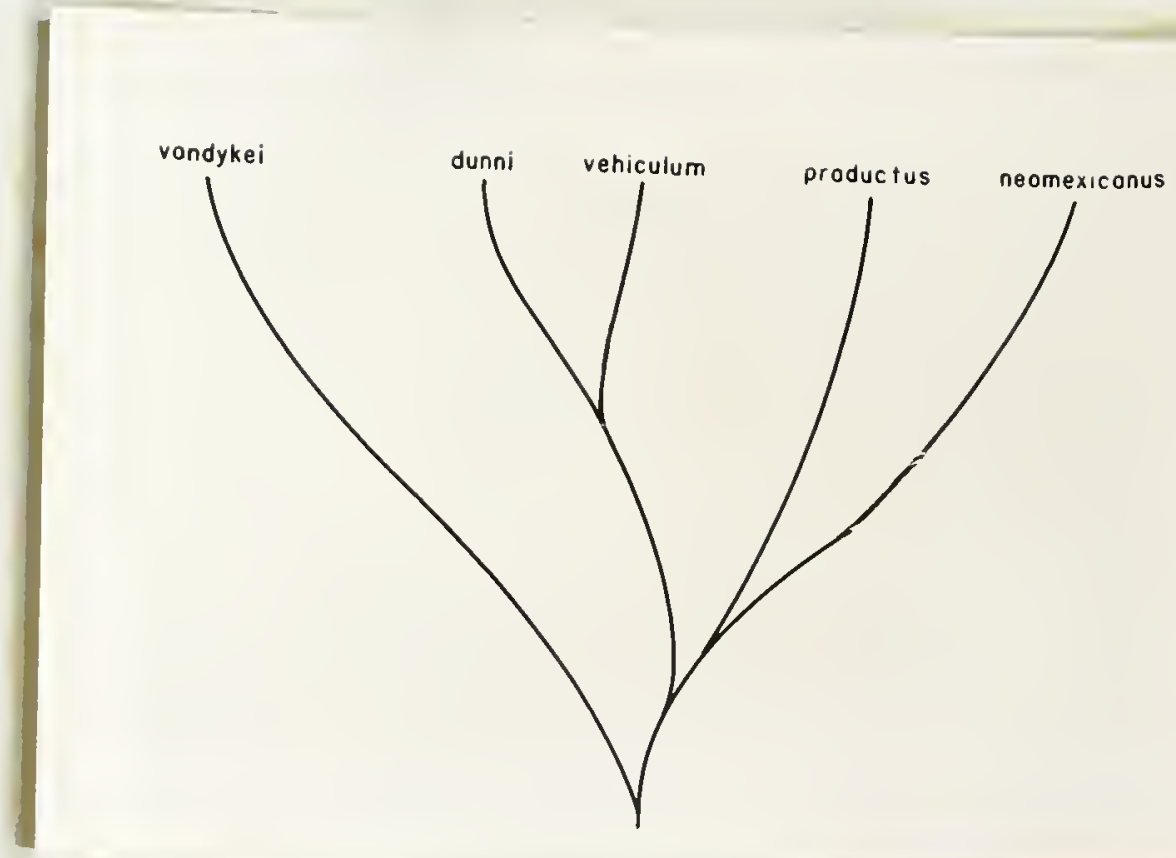

Figure 3. Sug ested phylogeny of the Vestern Plethodons. 


\section{Plethodon vandykel G:oup}

\section{Plethodon vandyke1}

This species is known from the Coast Range, Olympic lountains, and Cascade Mountains of westem iashington; Coeur d'hlene Lake, in northern Idaho; and from Larch Lountain, irultromah Gounty, oregon. The Idaho population was described as a distinct species (idahoensis) by Slater and Slipp (1940: 38), but has boen considerod a subspecies of vandykei by Lowe (1950: 93) and more recent warkers. Although the Idaho and hishingtion populations of this species are usualiy believed to be isolated from one another, Savage (1952: 183) suggests that they may be connected by a corridor of high humid country along the international boundary between Kashington and British Columbia. The two forms, idahoensis and vandykei, apparently differ mainzy in color characters.

In 1954, Burns discovered Plethodon vandykei in Multnomah County, Oregon. Two specimens from Larch Mountain were unusual in possessing red bellies. A series of eleven specimens collected on the north side of the Columbia River, at Archer Falls, Skamania County, Washington, also agreed in coloration with the Oregon specimens and this red-bellied form was described as the third subspecies of vandykei, ‥ ‥ larselli.

Stebbins (1951: 80-1) states that there are two color phases of $\underline{P}$. $\mathrm{V}$. vandykei. The light phase has the color of the belly and sides very similar to that of the dorsal stripe, while the dark phase has a darker lateral and ventral pigmentation.

This species is usually found in very damp situations and thus replaces $\mathbf{P}$. dunni ecolorically, as well as geographically. It has re- 
cently been shown that their ranges do overlap slightly in Wultnomah County, Oregon (Burns, 1954: 85) and Hacific County, Washington (Storm, 1955: $64-5)$.

Plethodon vandykei vandykei Van Denburgh Plethodon vandykei Van Denburgh (1906: 61). Dunn (1926: 151-3). Slater (1933: W4). Bishop (1943: 275-8). Storm (1955: 64-5). Plethodon vandykei vandykei Van Denburgh. Lowe (1950: 93). Stebbins (1951: 80-4). Stebbins (1954: 56-7). Slater (1955: 132-3).

Type:- CAS 6910 (now destroyed), collected at Paradise Valley, Mount Ranier National Park, washington, by E. C. Van Dyke, in July, 1905.

Diagnosis:- A Westcm Plethodon with 15 trunk vertebrae. It differs from idahoensis in having a wider dorsal stripe, lighter ground color, and by presence of yellov pigment like that found on the dorsum on the proximal segment of the limbs.

Range:- Knom from westem liashington, from Clallam County south to Fam cific County and east to Pierce County (see figure 4 ).

Description:- This subsyecies has not been seen in life and only four preserved specimens were exarined. Stebbins (1951: 80-1) gives detalled color notes on this form.

Costal grooves usually nurber 14 and the trunk vertebrae 15. In the available specimens, vonerine teeth range from 7 to 10 in a series. The largest individual is $56 \mathrm{~mm}$. in snout-vent length. 


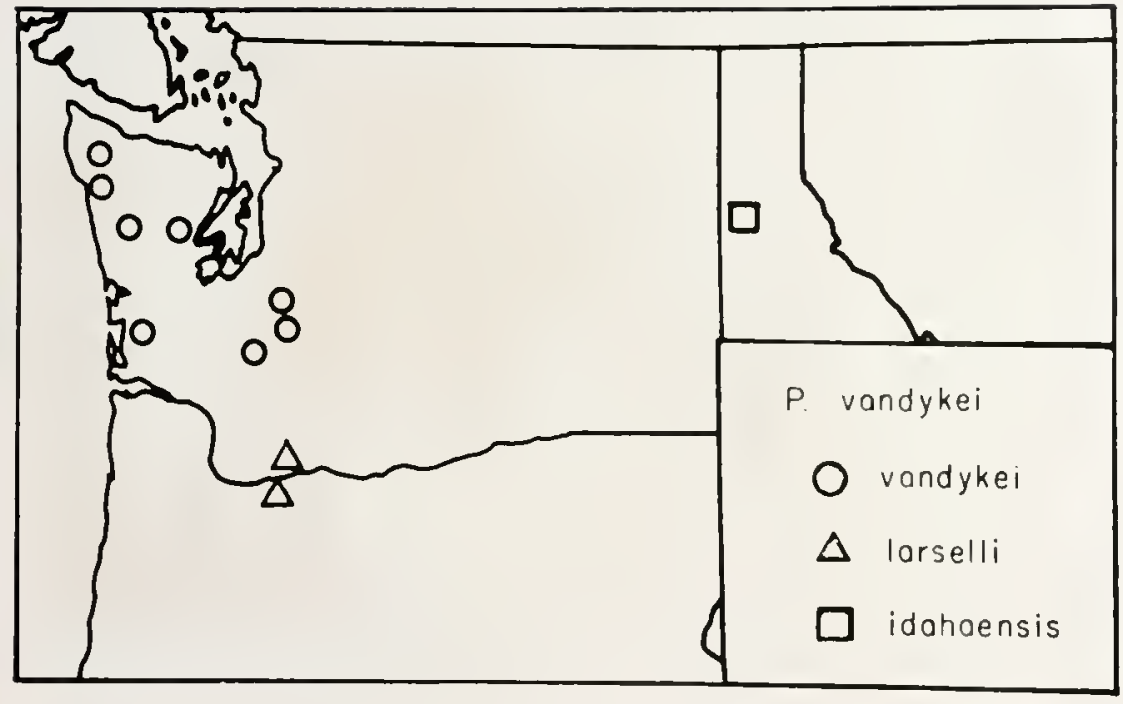

Figure 4. The distribution of the subepectes of Plethodon vandvkei in Washington, Oregon, and Ideho. 
Plethodon vandykei idahocnsis Slater and Slipp

Plethodon idahoensis Slater and Slipp (1940: 38). Slater (1941: 81, 85, 103). Bishop (1943: 259-61). Hilton (1948: 120).

Plethodon vandykei idahoensis Slater and Slipp. Love (1950:93). Stebbins (1951: 80-4). Stebbins (1954: 56-7).

Type:- USM 110504, an adult male, collectel at the northeast comer of Coeur d'Alene Lake, Kootenai County, Idaho, at an elevation of 2160 reet, by James R. Slater, on September 13, 1939.

Diagnosis:- A race of Plethoion vandykei in which the yellow or orange dorsal stripe is narrower then in $\underline{P} \cdot \underline{\mathrm{v}}$. vandykei and contrasts sharply with the lateral black ground color, and the proximal segments of the limbs are dark in color.

Range:- Known only from the type locality in northerm Idaho (Pligure 4). Deccription:- The back has a dorsal orange or yellow Iipophore stripe. The rest of the animal is pigmented with melanophores, except for melanophore gaps on the chin where there are yellow lipophores. There are also brassy guanophores in the iris, and a few scattered white guanophores on the belly and sices.

The costal grooves usulily number 14 , the trunk vertebrae 15. Vomerine teeth range from 5 to 12 in a series. Of 15 specimens examined, the largest is $56 \mathrm{~mm}$. In sncut-vent langth.

\section{Plethodion vandyjrei larselli Lums}

Plethodon vandykei larselli Burns (1954:83-7). 
Type:- USNM 134129, an adult male, collected on the north slope of Larch Mountain, three miles from the summit on the linutnomah Falls Trail, Minltnomah County, Oregon, on May 2h, 1953, by Douglas H. Burns.

Diagnosis:- A race of Plethodon vandykei in which the ventral color is cardinal red to redish orange.

Range:- Known only from the type locality and from Archer Falls, Skamaria County, Vashington (figure 4).

Description:- Specimens of this subspecies have not been examined and reference should be made to the original description for details of structure and coloration.

\section{Plethodon vehiculum Group}

\section{Plethodon dunni Bishop}

Plothodon dunni Bishop (1934: 169). Jewett (1936: 71). Fitch (1936: 637-8). Graf, Jewett, and Gordon (1939: 102). Gordon (1939: 55-6). Slater (1939: 154). Bishop (1943: 242-6). Stebbins (1951: 68-72). Stebbins (1954: 54-5). Storm (1955: 64-5). Dumas (1955: 65). S1ater (1955: 132).

Type:- USNM 95196, an adult female, collected just outside the city Ilints of Portland, Clackamas County, Oregon, by Stanley G. Jewett, Ir., on January 13, 1934 .

Diagnosis:- $\Lambda$ Western Plethodon with 16 trunk vertebrae.

Range:- Curry County, in southeastern Oregon, north to Facific County, 
Washington, east to the western slope of the Cascade Mountains (figure 5).

Description:- The dorsal stripe is made up of yellowish green lipophores. This pigment also occurs in abundance on the sides, but is ro duced on the belly. On the lower sides and belly there are a few yellowish guanophores. There are brassy guanophores in the iris.

The costal grooves usually nuaber 15 , the trunk vertebrae 16. The medial end of the vomerine series projects posteriorly toward the parasphenoid patches, so that the tro vomerine series form a $V$. Vomenine teeth range from 4 to 13 in a series. The largest specimen examined is 65 ran. in srout-vent length.

P. dunni is closely related to $\underline{\underline{P}}$. vehiculum, but differs in size, coloration, number of vomerine teeth and number of body segments. It occurs from southwesterm Washington south through ccastal Oregon. This species occurs sympatrically with $\underline{P}$. vandykei in southwestern Washington, with $\underline{P}$. productus in southwestem Oregon, and with $\underline{P}$. vehiculum throughout most of its range.

P. dunni is apparently the most aquatic Plethodon. Stebbins (1951: 70) states that it is almost invariably found in places that are saturated with water, and that it will often take to the water in an attempt to escape capture.

lost individuals possess a dorsal stripe that is greenish yellow in color, but Stebbins (1951: 69) reports that melanistic specimens lacking the dorsal stripe have been found in Benton County, Oregon. 


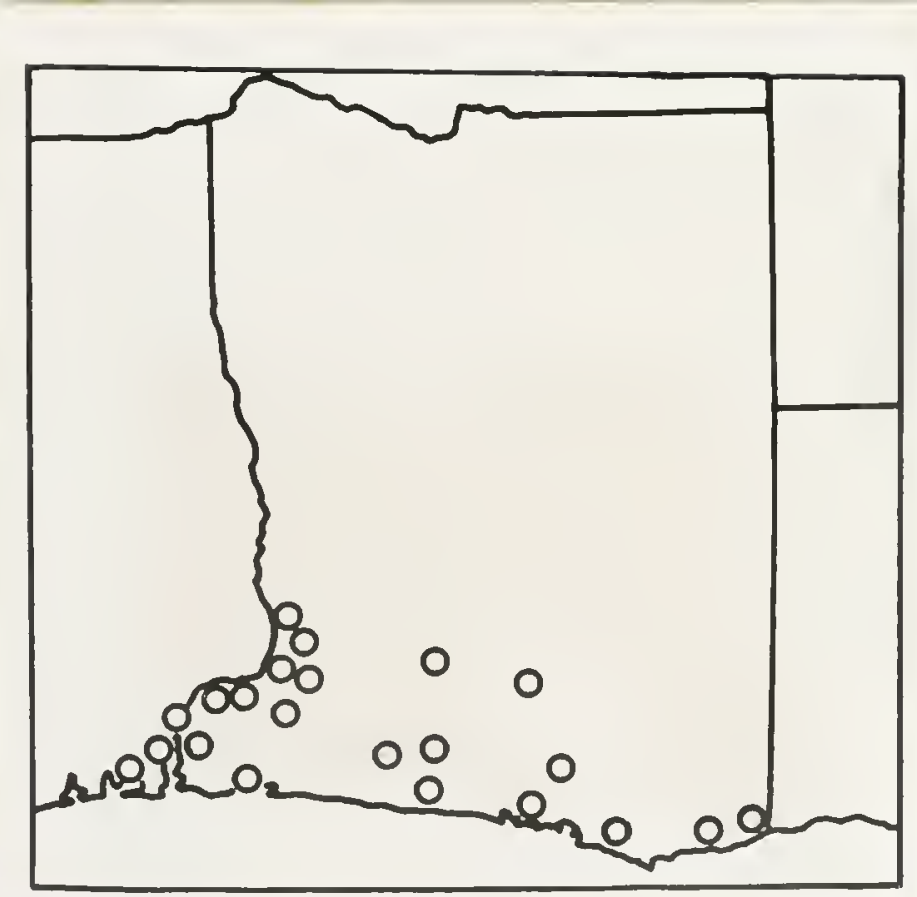

Figure 5. The distribution of Plethodon dunni in Oregon and southwestern Vashing:on. 


\section{Plethodon vehiculum (Cooper)}

Ambystoma vehiculum Cooper (1860: pl. 31, fig. 4).

Plethodon intermedius Baird (in Cope, 1867: 209). Cope (1869: 100). Strauch (1870: 72). Boulenger (1882: 57). Cope (1883: 23). Gaman (1884: 38). Cope (1889: 145-7). Cox (1907: 52). Van Denburgh (1916: 218-9). Fowler and Dunn (1917: 25). Hardy (1926: 22). Kernode (1926: 35). Dunn (1926: 154-6). Slevin (1928: 52-5). Logier (1932: 317-8). SJ.ater (1933: 44). Svihla (1933: 39). Slater (1934: 140-1). Slevin (1934: 46). Cowan (2937: 18).

Plethodon vehiculus (Cooper). Bishop (1934: 171). Jerrett (1936: 71). Watney (1938: 89). Slater (1939: 154). Graf, Jewett, and Gordon (1939: 10-1). Brown and Slater (1939: 9). Plothodon vehiculum (Cooper). Slater (1940: 43). Slater and Brown (1941: 75-7). Bishop (1943: 278-81). Stebbins (1951: 84-7). Stebbins (195): 57-9). Logier and Toner (1955: 17). Slater (1955: $133-4)$.

Type:- Apparently no longer in extstance. The type locality is Astoria, Oregon.

Diagnosis:- A Westem Plethodon with 17 tmuk vertebrae.

Range:- From Coos County, in southwestern Oregon, north to southwestern British Columbia, including Vancouver Island (figure 6).

Description:- Lipophores in the region of the dorsal stripe may be absent, producing a uniformly colored phase, or present, resulting in a 


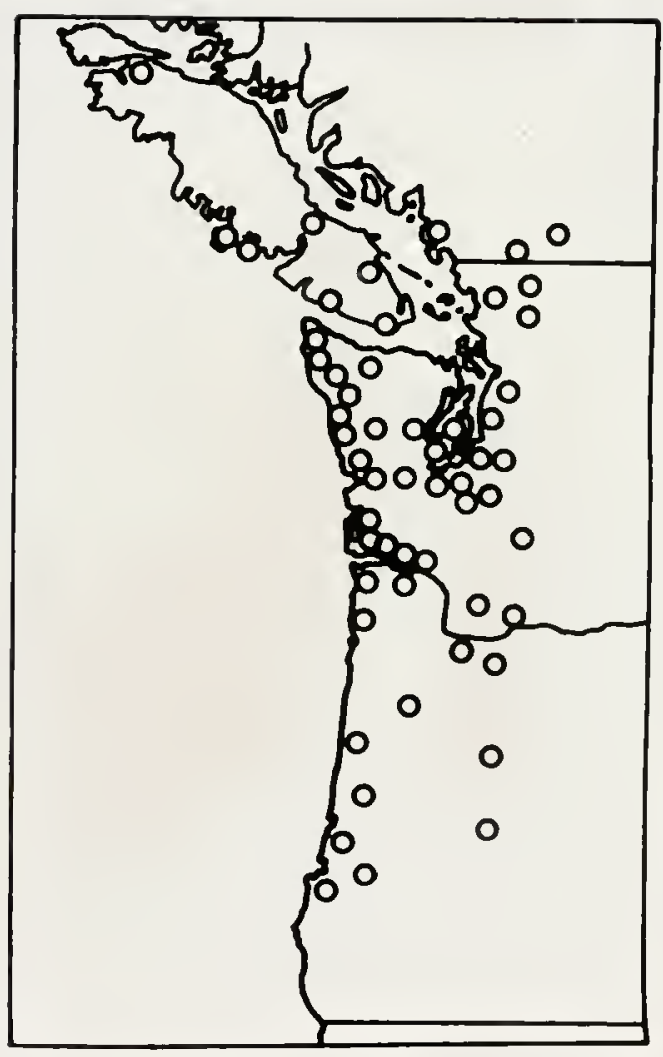

Figure 6. The distribution of Plethodon vehiculum in Oregon, washington, and British Columbia. 
striped phase. The color of the dorsal stripe is quite variable, varying from light yellow, through yellow, orange, and red to brown. The lipophores are absent from the sides, but are present on the belly. The sides are black with only a few small white guanophore spots. These are also present on the belly, and along with the melanophore and lipophore pigmantation give it a mottled appearance. Small white guanophore spots similar to those on the sides, as well as smaller brassy flecks, are present on the dorsum of the dark phase individuals. Erassy guanophores are present in the iris.

Costal grooves usually number 16, tmunk vertebrae 17. Vomerine teeth range from 3 to 7 in a series and the two series converge posterforly to form a $V$ as in dunnt. The largest speciraen 49 examined is $51 \mathrm{~mm}$. in snout-vert length.

This species is the smallest Western Plethodon and has the largest range. It is the most abundant plethodan over most, of its range. P. vehiculum is superficialiy quite similar in appearance to the easterm I. cinereus. Dark and striped phases are present and the belly is mottled in both species. The similarities between the two are probably due to convergence or parallel evolution because in all other characters, $\underline{P}$. vehiculum is morphologically more similar to the other liestern Plethodons.

\section{Plethodon productus Group}

\section{Plethodon productus, new name}

Plethodon elongatus Van Denburgh (1916: 216-8). (non) Salamandra elongata Valenciennes in Dumeril and Bibron (1854: 84). Grinnell and 
Camp (1917: 134). Storer (1925: 21, 104). Duinn (1926: 156-8). Slevin (1928: 55-7). Slevin (1934: 46-53). Mood (1934: 191). Fitch (1936: 638). Wood (1939: 110). Gordon (1939: 13, 30, 56). Bishop (1943: 246-9). Hilton (1946: 45). Stebbins and Reynolds (1947: 4I-2). Stebbins (1951: 72-6). Stebbins (1954: 55-6).

Type:- CAs 29096, collected at Requa, Del Horte County, California, by J. R. Slevin, May 22-26, 1912.

Diagnosis:- A Vestern Plethodon with 19 trunk vertebrae.

Range:- Southwestem oregon and northwestorn California (ficure 7).

Description:- The belly of this species is very dark with a few sacttered white guanophore spots. The orange to reddish brown dorsal lipom phore stripe is usually brighter in juveniles than in adults, where it is often reduced or absent. Often it is divided into a right and left dorsolateral stripe by the presence of medial melanophore plgment.

The costal grooves usually number 18 , the trunk vertebrae 19. Vomerine teeth range from 4 to 7 in a series. This is a large species, the largest of 18 specimens examined is $66 \mathrm{~mm}$. in snout-vent length.

This is the most elongnte of the Nestern Plethodons in the Pacific Northwest. Its greatcr number of body segments distinguishes it from the species vandvkei, dunni, and vehiculum, and its rebbed toes also distinguish it from tho last tro. It is probably more closely relatod to $\underline{P}$. neomexicanus than the other Westcrn Flethodons. $\underline{\text { P. productus }}$ has a rather limited distribution. It is know only from Irinity, Humboldt, and Del Norte Count1es, Celifornia; and Curry County, Oregen. 
$-45-$

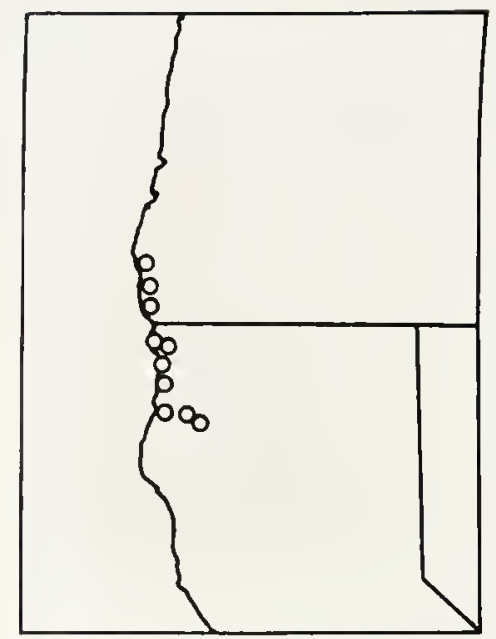

Figure 7. The distribution of Plethodon productus in Califomia and oregon.

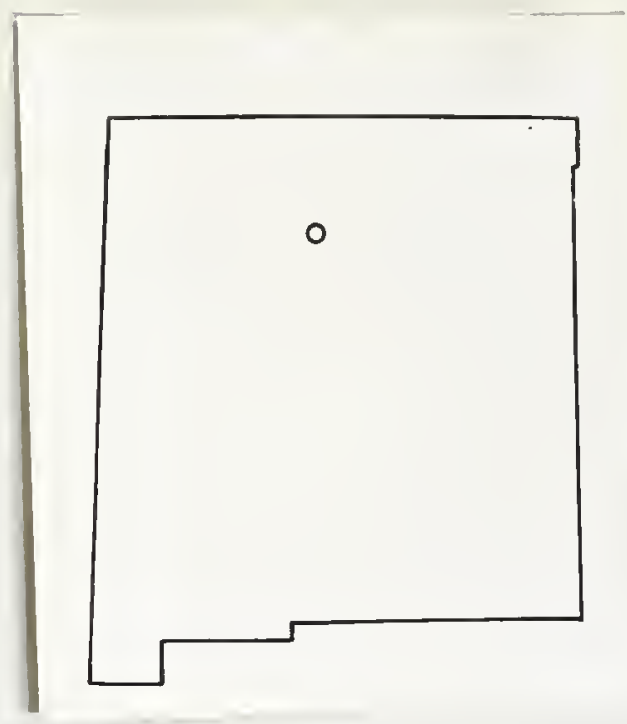

Figure 8. The distribution of Plethodon neomexicanus in Wew íexico. 


Stebbins (1951: 76) believes that specimens from the interior of the range differ in several respects f'ron those on the coast.

Van Denburgh described this species in 1916, apparently without realizing that the name he rroposed, elongatus, was a junior homonym of Salamandra elongata Valcnciennes (in Dumeril and Bibron, 1854: 84) (= Flethodon glutinosus). This is a primary homonym due to the fact that the name elongata is available for Plethodon glutinosus, although the combination Plethodon elongatus has never been used for the slim salanander. No subsequent worker has proposed a new name to replace the preoccupied name of the Del Norte salamander and it has always been referred to as Plethodon elongatus. This species has been know by the name elongatus since 1916 and it is unfortunate that the name has to be changed, but there is no alternative than to propose a new narae in place of the preoccupled elongatus. The name productus also refers to the elongated condition of this species.

\section{Plethodon neomexicanus Group}

\section{Plethodon neomcxicanus Stebbins and Riemer}

Eurycea multiplicata (Cope). Dunn (1926: 312-4, part). Plethodon neomexdcanus Stebbins and Piemer (1950: 73-80). Stebbins (1951: 76-9). Stebbins (2954: 58).

Iype:- UVZ 49033, an adult male, collected 12 miles west and 4 miles south of Los Alamos, Sandoval County, New l'exico, at an altitude of about 8750 feet, by Robert Stebbins, on August 14, 1949.

Diagnosis:- A Testern Plethodon with 20 trunk vertebrae. 
Range:- Know only from the vicinity of the type locality in the Jenez Mountains of Ner Mexico, (fikgre 8).

Description:- This species has not been exanined in Iife and referenco should be made to the original description for an account of the pigmentation.

Costal grooves are usually 19, trunk vertebrae 20 . Vomerine teeth range from 4 to 11 in a series in the 7 specimens examined. This is a large species, the type is over $70 \mathrm{~mm}$. In snout-vent langth. According to the data listed in Stebbins and Riemer (1950: 75), sexual maturity is not reached until approximately $50 \mathrm{~m}$. in snout-vent length.

This is an elongated salamander, with the largest number of trunk vertebrae of any of the western forms. It is unusual in that most specimens have only one phalanx on the fifth toe of the hind limb instead of the usual two phalanges. This is probably an intemediate stage in the loss of the fifth toe and reluction to the four-tocd condition lnovn to have occurred in several unrelatod salamander genera.

The dorsal stripe is apparently absent in adults, but yresent in juveniles. This form is unique anong the hestern Plethodons in lacking the striped phase in the adult, and also in possessing a large number of brassy Euanophores on the dorsun.

The Eastern Simall Plethodons

The Eastern Small Plethodons are characterized by their small size. Except for P. welleri, they possess a higher number of trunk vertebrae and are relatively nore elongate than the Eastern Large 
Flethodons. Four species are included in this group. P. welleri has a restricted range, and is known only from a few counties in northwestern North Carolina and adjacent lennessee and Virginia. P. richmondi is a polytypic form with three described races, and probably others which have not yet been defined. Its range centers in the Appalachien Plateaus ihysiographic Province and it also occurs in immediately adjoining areas of several adjoining provinces. P. cinereus, with three subspecies, has the widest range of any Eastern small Plcthodon, occurring over most of eastern United States and southeastem Canada, except in the region occupicd by $\underline{P}$. dorsalis. The range of P. dorsalis is centered in the Interior Low Hateaus Physiographic irovince. $\underline{P}$. d. angusticlavius is here regarded as a subspecios of dorsalis, rather than of cinereis, as originally described by Grobman (1944: 302 ).

The four species forn a natural group of closely related forms. All possess webled toes, a pigmented peritoneurs, low vonerine tooth counts, brassy fleclis on the dorsum, and white glanophore spots on the belly and sicies. Two species, cinereus and dorsalis, aro more sinilar to each other tilan cither is to welleri or richmondi. Both cinereus and dorsalis typically possess at least as much white as black pifment on their bellics, and both are characterized by the presence of a redb-cked phase in which there is a dorsal band of red or yellow lipophore pigmentation on the dorsum of the body and tail. In richmondi and velleri, the white pifment on the belly is linited to small spots and there is a much greator amount of black pigment than white. The redbacked phase, present in all of the races of dorsalis and cinereus, 
is always absent in richmondi and velleri.

P. r. richmondi is the largest form, and also possesses the greatest number of trunk vertebrae, but both size and number of vertebrae are slightly reduced in the race popei, and decrease still more in the subspecies netting. Geographic variation in the number of trunk vertebrae is most pronounced in this species, with a range of 18 to 24 in all of the subspecies. P. welleri is less elongate and has fewer vertebrae than other small eastem species. It is unusual in its possession of ovarian eggs pigmented with melenophores, as well as in having an extrenely dark partetal peritoneum. The brassy flecks on the dorsum of welleri are concentrated to form large patches, giving it a unique appearance not found in any other Plethodon. Its nearest relative is probably P. r. nettingi, but welleri is closest geographically to $\underline{P} \cdot \underline{r} \cdot$ popet.

In most of their ranges, cinereus and dorsalis are allopatric forms, but in several areas where their ranges meet, there are records of the two occurring together in the same locality (see below). In each of these instances, there is no good evidence for hybridization or intergradation between the two forns, and for this resson they are usually considered as distinct species. They differ in several pigmentation characters, as well as in the average number of trunk vertebrae and the shape of the mental gland in adult ma?es. P. icraglis usually has 19 trunk vertebrae (range 18-20). Two races of cinereus typically have 20 tmunk vertebrae (occasionally 19 or 21), while the third subspecies (polycentratus) usually has 21 or 22 (rarely 23) trunk vertebrae. In all of the Eastern Small Plethodons except dorsalis, 
the mental gland is rather poorly developed and difficult to differentiate (except, perhaps, during the breeding season) from the adjacent portion of the chin. In dorsalis, on the other hand, it is a distinct rounded elevated gland, as in the Eastern Iarge Plethodons. Dunn (1926: 24) suggests that the striped pattern or dorsalis is more primitive than that of cinerens, since the paired red dorsal spots of several prinitive plethodontids might be expected to pass through a zig-zag striped phase similar to that of dorsalis before evolving into a uniformly straightedged stripe.

In 1944, Grobman described the narrow-striped populations occurring in southwestem Missouri and northwestern Arkansas as a distinct subspecies, Flethodon cinereus angusticlavius. This form possesses several characteristics that appear to link it more closely with dorsalis than with cinereus. It usually has 19 trunk vertebrae, as in dorsalis, while cinereus populations to the northeast and south of the range of angusticlavius usually have 20 trunk vertebrae. The mental gland is of the dorsalis type and in some specimens the dorsal stripe has irregular edges anterforly, resembling very closely the pattern in dorsalis. living specinens of angusticlevilus have not been examined, so no accurate information is available on pigmentation characters, but the other characters strongly suggest that angusticlavius should be linked subspecifically with dorsalis rather than cinereus.

The elongation and increased number of trunk vertebra in $\underline{P}$.

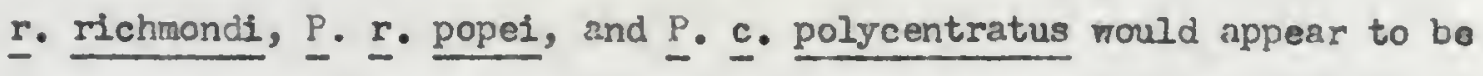
a marked specialization of the usual plethodontid type. The forms welleri and dorsalis would appeer to have retained more primitive char 
acteristics, but both have probably changed considerably from their common ancestor. The relationships of the Fastern Small Plethodons would appear to be best indicated by the phylogeny outlined in figure 9.

\section{Plethodon welleri Group}

\section{Plethodon welleri Walker}

Plethodon welleri Walker (1931: 48-51). Walker (1934: 190). Bishop (1943: 285-7). Grobman (1944: 313). Snyder (1946: 174). Hoffman and Keinpeter (19482: 107). Hoffman (1953: 86-7).

Typo:- USNM 84135, an aduIt male, collected on Grandfather Mountain, at an altitude above 5000 feet, near Linville, llorth Carolina, by V. H. Weller and Ralph Dury, on August 27, 1930.

Diagnosis:- A dark-bellied, Easterm Small Plethodon with 17 trunk vertebrae and abundant dorsal brassy spotting.

Range:- From Yancey County, North Carolina, northeast in Tennessee and North Carolina to $\mathrm{N}^{4}$. Rogers and White Top Mountain, Virginia (figure 10).

Description:- The dorsal pattern consists of large anastomosing patches of brassy guanophore spots. These spots appear to consist almost entirely of brassy guanophores, the white type of guanophore pigmentation present on the sides of welleri and on the dorsun of rost plethodons, is not evident on the back of wrelleri. The brassy pigment is more concen trated than in any other form and the appearance of the dorsal spots is similar to the large white spots of glutinosus, except for the color, 


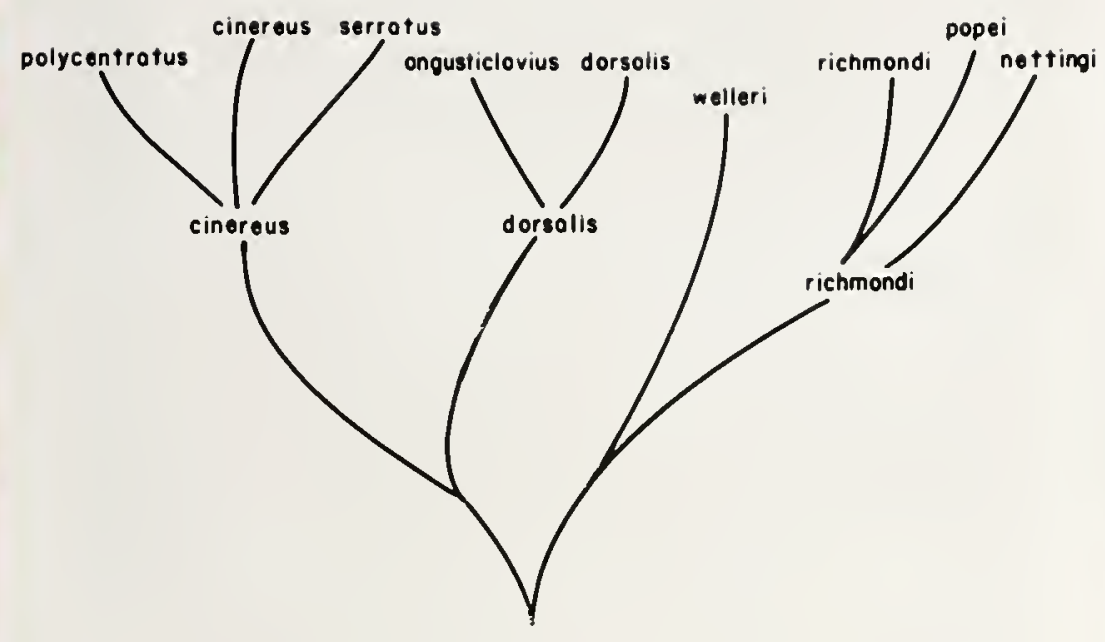

Figure 9. Suggested phylogeny of the Eastern Small Plethodons.

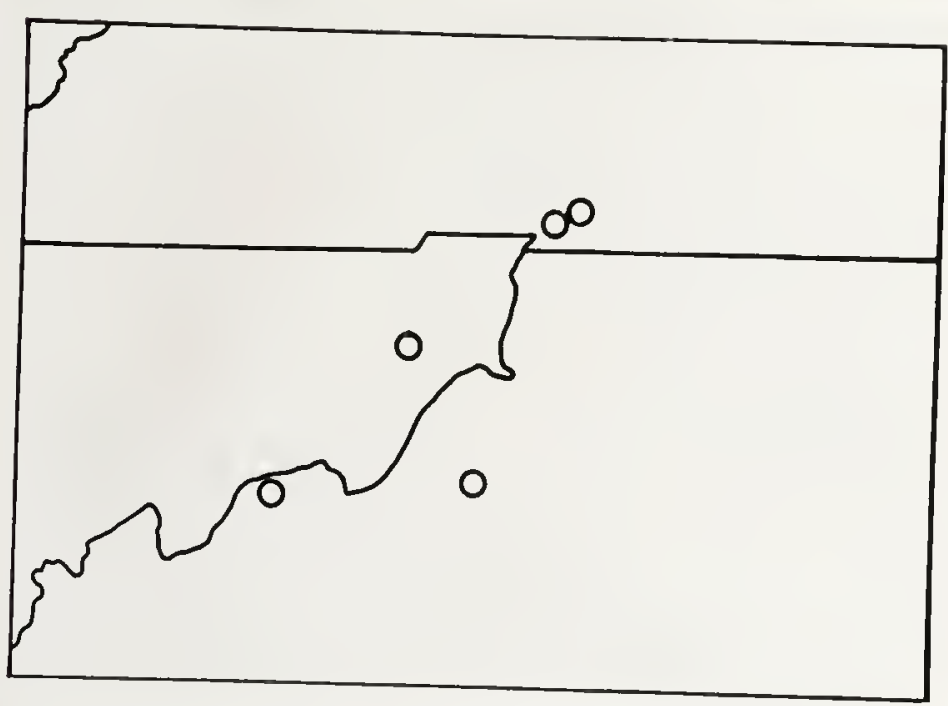

Figure 10. The distribution of Plethodon welleri in North Carolina, Tennessee, and Virginia. 
which is brassy. Small white spots (0.1-0.2 non.) are scattered over the belly and are similar to those of P. I. popei. The lateral spots (up to $1 \mathrm{~mm}$. in diameter) are white with a slight mount of brassy flecking.

The costal grooves usually number 16, the trunk vertebrae 17. Vomerine teeth range from 2 to 7 in a series. In the 39 specimens exanined, maximum known snout-vent length is between 4.5 and $50 \mathrm{~mm}$. Sexual maturity is reached at about $35 \mathrm{~mm}$. In snout-vent length.

P. welleri is the least elongate of all of the Fastern Small Plethodons, with the same number of tronk vertebrae (17) as in most of the Lastern Large Flethodons. In body build it resembles the large forms more than any other Eastern Small Plethodon. Its small size, vertebral structure, webbed toes, and pigmentation characters would appear to associate it more closely with the other small eastern forms.

This species has long been believed to be restricted to high elevations and was recorded only from Flat Top Mountain and Grandfather Mountain, North Carolina; and Nt. Rogers and Wite Top Hountain, Virginia. Recently, Horfman (1953: 86) collected the species at an elevation of 2500 feet in Johnson County, Tennessee. I visited this locality during the sumer of 1955, and although conditions were very dry, succeeded in collecting one young specimen, thus confirming Hoffman's record. This species mag well occur in suitable habitats at low altitudes throughout the region.

Walker (1934: 190) has pointed out that individuals from Whito Top Mountain, Virginia, possess more spots on their venters than individuals from the type locality, Grandfather Ifountain, North Carolina. 
Specimens from Mt. Royers (USH 124h21-9) also possess spotted bellies. One specimen fron Fat lop Mountain, Yancey County, reported by Snyder (1946: 174) is also descrioed as having a more conspicuous mottling on the venter. Perhaps the Grandfather Iountain population is unusual in lacking this characterlstic. The low altitude specinen from Tennessee has a greater emount of dorsal brassy pigment than eight living topotypes from Grandfather Mountain. I have not examined living specimens from any of the other localities.

P. Felleri is unusual in possessing dark ovarian eggs that are pigmented with melenophores. Its closest rolative is probably $\mathbf{P}$. richmondi, which it resembles by the presence of a dark belly. F. $\underline{r}$. nottingi usunlly has 19 trunk vertebrae, although ccersional specinens possess 18 or 20 . Since a $5 m 21$ persentage of welleri also have 18 trunk vertebrae (table II), there is slight morphological overlap botween the two forms in this character.

\section{TABLE II}

THE NUUBER OF TRUNK VERTELIAE IN GEOGRAPHIC SAMPLES OF PLETHODON WELLERT

Locallty

llumber of trunk vertebrae

\begin{tabular}{lccc} 
& 16 & 17 & 18 \\
\hline Srandfather Mountain, North Carolina & 25 & \\
Johns on County, Tennessee & 1 & \\
White Top Mountzin, Virginia & 4 & \\
St. Rogers, Virginia & 1 & 6 & 2 \\
\hline
\end{tabular}




\section{Plethodion richnondi}

In 1938, two new Eastem Sinall Plethodons, P. richmondi and P. netting1, were described by Netting and Mttleman (1938: 297) and Green (1938: 295). Both are characterized by their dark bellies and brassy dorsal flecking. Available samples of richmondi from ohio and West Virginia possess 20 to 22 costal grooves (21 to 23 trunk vertebrae), while ․ nettingi has 17 to 19 costal grooves ( 18 to 20 trunk vertebras). They both differ from $\mathrm{P}$. C. cinereus in the number of vertebrae, and they are distinguished from the entire cinereus group by their dark bellies and lack of red pigment. Most previous writers are in agreoment that these two forms, Fichmondi and nettingi, are more closely related to each other, and to welleri, than they are to cinereus and dorsalis (Netting and Mittleman, 1938: 292; Green: 1938: 298; Grobman, 1944: 311).

In 1949, Grobman described arother flacked plethodon (․ huldae) which he assigned to this group because of its heavily flecked dorsum. This form possesses 20 trunk vertebrae, the same as cinereus, and also has a mottled belly as in cinereus. Rabb (1955: 261-3) and Wuchmore (1955: 170-2) present convincing evidence that huldae, although possessing brassy dorsal flecks similar to those of richmondi and nettingi, is actually based on dark-phase specimens of $\underline{P}$. cinereus. muchmore (1955: 172) goes so far as to state that "since $\underline{P} \cdot \underline{c}$. cinereus possesses brassy flecks on the dorsun and since $\underline{P}$. huldae can no longer be considered valid, it is certainly desirable that the concept of a welleri group of Plethodon distinct from a cinereus group be abandoned." Obviously these forms are all more closoly related than any of then are to the Eastern Large Plethodons or the Western Plethodons, yet the fail- 
ure of ane suggested character to define the group should have no bear ing on the fact that other features are useful in distinguishing it (dark belly and lack of red dorsal stripe).

Netting and Mittlenaii (1938: 292) state that spacinens of $\underline{P}$. richrondi fros Wateuga County, North Carolina, differ Irom typical richmondi, but do not gfive any evidence to supnort this contention. Neither Bishop (1943: 239) nor Grobman (1944: 312) inclucie this localtty in their distribution meps of the range of richmondi, although Grobman mentions the literature reference to the North Carolina specimens. Wore recently, Hoffman and Hubricht (1954: 192) report richnondi from several localities in southwestern Virginda and northwestern North Carolina, but do not find any consistant differences between these specimens and topotypes of richmondi. A study of their material and large series from this area in the University of Florida Collection have shom, however, that these scuthem richmondi are actually quite distinct in the number of trunk vertebrae from more northem richmonai. This southern form has recently been described as a new subspecies of richmondi, $\underline{P} . \underline{r}$. popei, by lileghton and Grobman (in press). No other character could be found to distinguish preserved specimens of popel and richmondi. Living specjmens of $\underline{P}$. $\underline{r}$. Flchmondi have not been available during this study, so it has not becn possible to compare the pigmentation characters of the two forms.

On the basis of the slight overlap in distinguighing characters, as well as the geographic replacement of tho three forms, richmondi, popei, and nettingi, liighton and Grobman (in press) suggested that they should all be congidered subspecifically related. One 
matter, not discussed in their paper, is the apparent sympatric relationship of nettingi and richmondi. Although the two forms, to ny knowledge, have not been collected at the same locality, the entire range of nettingi, as summarized by Brooks (1948), is surrounded by records of richmondt.

Thurow (1955) has recently reported nettingi from Bedford County, Virginia, a locality about equidistant from the nearest known nettingi and popel localities. An examination of these specimens (CNHM 60512-8) confirms Thurow's suggestion that they belong to this group. Although they are poorly preserved, their dark bellies indicate that they are not dark-phase cinereus. They differ from both nettingi and popei, however, in costal groove count. Five of the seven specimens have 19 costal grooves, while the other two have 18. The sample is small, but the probability that they were taken from a populam tion of nettingi similar to that in Randolph and Pocahontas Counties, Vest Virginia, which has 19 costal grooves less than $5 \%$ of the time, is very low. Four of the seven Bedford County, Virginia, specimens have 20 trunk vertebrae, two possess 19, and the remaining specimen is too small to obtain an accurate count from the radiograph, but it probably also has 20 trunt: vertebrae, since it has 19 costal grooves. The population from which these specimens were collected probably represents an intcrmediate one between popei and nettingi. If the usual number or trunk vertebrae is 20 , and this occurs with high frequency, this population should probably be given separate subspecific nomenclatorial status. At present, with only seven poorly preserved specimens available, too little is known of its variation to described it as ner here. Its importance lies in the fact that an intermediate population, often 
possessing 20 trunk vertebrae, is known from a locality between the ranges of nettingt (usually with 19 trunk vertebrae) and popei (usually with 21 trumk vertebrae). This may be considered further evidence that nettingi and popel are subspecifically related.

In the Valley and Ridge Province of Virginia, there exists a population of P. . . richmondi which lioffman and liubricht (1954: 192) believe to be different in both color and structural features from other populations of $\underline{P}$. richrondi. They do not state the ways in which It differs, but an examination of preserved spectmens from this region (Alleghany and Rockingham Counties, Virginia) indicates that these animals, although possessing a vertebral count similar to michmondi, differ from it in having a mottled belly. Specimens from these counties aro easily segregated from topotypical richmondi and popei on the basis of the character of the belly. In ten specimens of the mottled bellied form for which vertebral counts are available, six possess 22, three 23, and one 24 trunk vertebrae. The average is slightly higher than the usual richmondi number, but does not differ significantly from it. It is quite likely that examination of Iiving specinens, and the accumulation of more data on vertebral counts may reveal differences which will indicate that this population represents a distinct nominal form. Specimens from other areas in the Valley and Ridge Province should bo studied in order to delimit the range of the mottledbellied richmondi.

The distribution of these forms indicates that there is probably a series of five races, two of them undescribed, each of which replaces its nearest relative geographically. One extre-n (nottingi) occurs sympatrically with the two at the other extreme (richnondi and 
the undescribed Virginia Valley and Ridge animal). Table III shows the variation in the vertebral counts of these populations.

\section{TABLE III}

GEOGRAPHIC VARIATION IN THE MUHBER OF TRUNK VERTEBRAE IN PLETHODON RICHIMONDI

\begin{tabular}{|c|c|c|c|c|c|c|c|c|}
\hline \multirow{2}{*}{ Sample } & \multicolumn{3}{|c|}{ Number of } & \multicolumn{3}{|c|}{ trunk vertebrae } & \multirow[b]{2}{*}{24} & \multirow[b]{2}{*}{ Moan } \\
\hline & 18 & 19 & 20 & 21 & 22 & 23 & & \\
\hline$\underline{P} \cdot \underline{r} \cdot$ nettingt & 1 & 22 & 1 & & & & & 19.0 \\
\hline Bedford County, Virginia & & 2 & 4 & & & & & 19.7 \\
\hline$\underline{P} \cdot \underline{r} \cdot$ popel & & & 4 & 51 & 12 & & & 21.1 \\
\hline P. I. richmondi & & & & 4 & 30 & 9 & & 22.1 \\
\hline $\begin{array}{l}\text { Alleghany and Rockingham } \\
\text { Counties, Virginia }\end{array}$ & & & & & 6 & 3 & 1 & 22.5 \\
\hline
\end{tabular}

The races of richmondi appear to form a ring of subspecies, none of which is completely distinct morphologically from the related adjecent form (or forms). $\underline{P}$. $\underline{\text {. }}$ nettingi is not know below 3550 feet elevation in the Cheat Hountains of west Virginia (Brooks, 1948) and

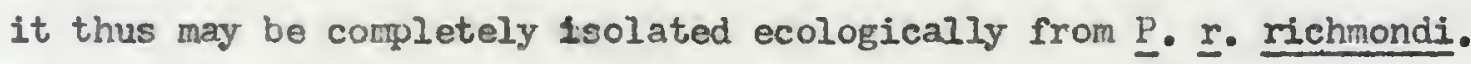
There is no information on the upper altitudinal linits of richmondt in the literature, but it is known from jocalities throughout most of West Virginia. A similar case has been reported by Stebbins (1949) for the westem salamander genus Ensatina, in which the two end forms of an allopatric series of subspecies occur in immediately adjacent regions 
w thout any evidence of interbreeding. An accurate momledge of the cological distribution of the overlapping forms of P. Fichnondi is lacking. There appears to be little or no overlap betwean the two terminal racos of Ensatina eschscholtzi, whereas in this case, one (nettingi) definitoly occurs within tho range of richmond1, for there are records of the latter to the north of the Cheat lountains in Pennsylvania, to the east and west in West Virginia, and to the south in Virginia.

In these series of populations we probably see the stages through which the subspecies of richrondi have differentiated. All of the forms probably have changed somewhat from the original stock, but the close sindiarty of all the forms, except for the number of body segments, would seem to Indicate that this change has not been great. It is difficult to deterrine wich form most closely resembles the ancestral condition. ‥ ‥ rechmondi is unlike most plethodons in its elongate form and would appear highls specializcd. On the other hand, It wide distribution and the fact that the oastern Valloy and HIdge population has a mottled belly, approaching that of the cinereus group, might be considered evidence that this form is a mors primitive gencm alized animal. It is possible to reconcile these vlewpoints, for it is often found that a given form is specialized in some ways, yet rotains certain other primitive characteristics.

Since P. . nettingl is apparently limited to high altitudes in the Cheat Hountains, it could be interproted either as a speciallzed type adapted to this habitat, or as a rolict of a once more widely distributod spruce forest population. At present, the evidence is not sufficient to choose between the tro altematives. On the basis of its 
fener trunk vertebrae, netting would appear to be less specilized than the other subspecies.

Intergradation between the races of richmondi may occur in certain regions. .. . netting may now bo completely isolated from Its nearest relativo, but the ranges of popal and richmondi probably meet in eastem Kentucky, and intergradation night be expected. Large earples from criticel arens will be necegsary before conclusive ovidence is obtained, since intergrades between popei and richmondi, for example, would be expected to possess about an equil number of specimens whth 21 and 22 trunk vertebrac. Iarge series of specimens from each county in and on both sldes of the area of intergradation yrould be neecossary to deternine its extent. Such series are not now avallable from lientucis, and hollow symbols representing literature records for this region on the distribution map (figure 11), maxy reprasent popel, intergradient, or richmondi populations.

Plethodon richmondi richmondi Notting and Hittloman Plethodon Yichmondi lotting and littleman (1938: 207). Detting (1939: 50-1). Iury and Gessing (1910: 31). Bishor (1943: 272-5). Grobman (1944: 322). Wood (1015a: 49). Tood (19L5b: 206-10). Netting (19t6: 12). Wood (1946: 169). Wood and Dhelimen (1947: 3). Grob$\operatorname{man}(1949: 135)$. xchmond (1952: 314). Green and walker (1954: 60). Thellinan (1954:40-5). Jorman and Fubricht (1951:191-3). Plethodon richmond Mchmonds lietting and Listieman. Wighton and Grobthen (in press).

Type:- Cu 34189, an adult mele, collected in Fitter Park, liuntington, 
Cabell County, West Virginia, at an elevation of 600-700 feet, by Neil D. Richmond and N. Eayard Green, on October 15, 1938.

Diagnosis:- A dark-bellied Dastern Small Plethodon, usually with 22 trunk vertebrae (range 21-24), which completely lacks red pigment.

Rango:- From Centre County, Pennsylvania, south through western Maryland, Piest Virginia, and northwestem Virginia, west to northeastem Kentucly, and north to southern and eastem Ohio (figure 11).

Description:- This form has not been examined in life and nothing on the pigmentation can be added to prevlously published accounts.

The costal grooves usually number 21 , the trunk vertebrae 22 . Vomerine teeth range from 3 to 9 in a sories. This is the largest Eastern Small Plethodon, the largest specimen examined, from Alleghany County, Virginia, is $60 \mathrm{~mm}$. in snout-vent length.

Plethodon richmondi popei Highton and Grobman Plethodon richmondi Netting and Kittleman. Barbour (1953: 85-6). Hoffman and Hubricht (1954: 191-3).

Plethodon richmondi popel Highton and Grobman (in press).

Type:- UF 8226, a maturing inale, collected at Comers Rock, GraysonWythe County line, Virginia, by Arnold B. Grobman and Mare R. Grobman, on August 5, 1955.

Diagnosis:- A race of Plothodon richmondr that usually possesses 21 trunk vertebrae (range 20-22).

Range:- Know from Harlan County, Kentucky; Tazewell, Stoth, Grajson, 


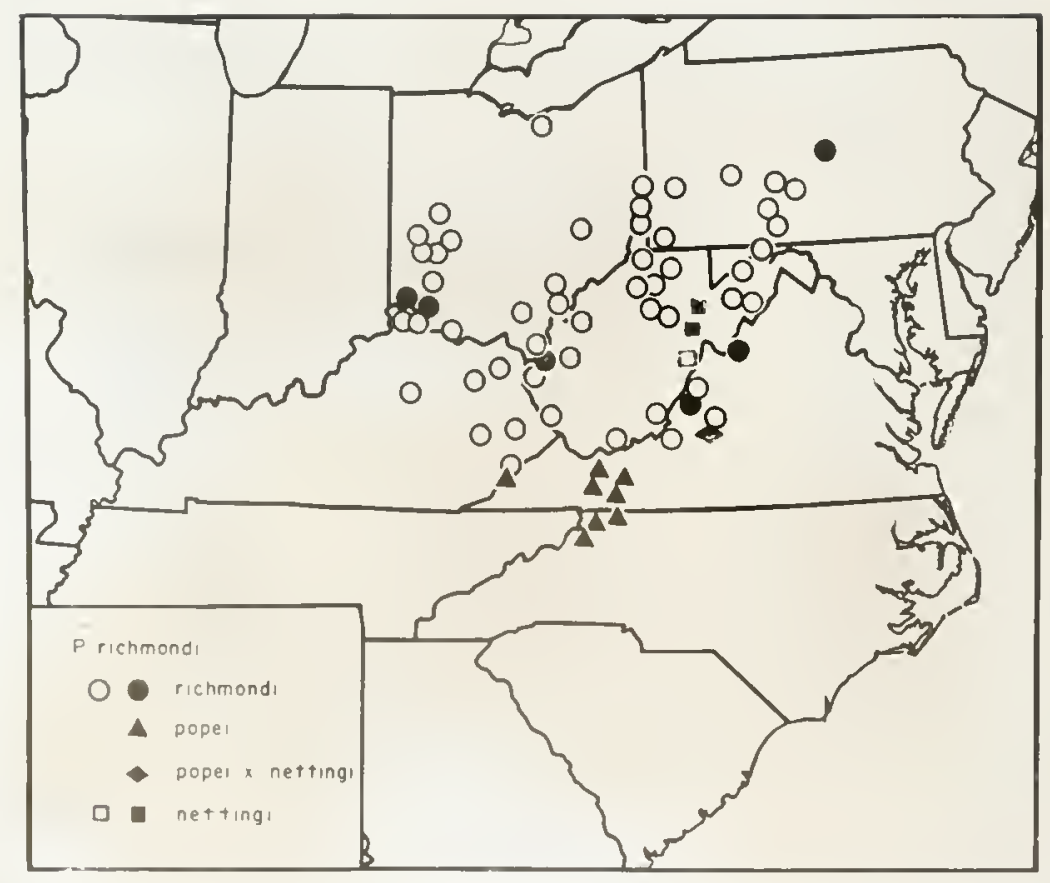

Figure 11. The distribution of the subspecies of Plethodon richmondi. Solid symbols represent localities from wh Lh specimens have been examined. Hollow symbols, represent literature records. 
and Wythe Counties, Virginia; and Ashe, Alleghany, and Vatauga Counties, North Carolina (figure 11 ). This form may have a greater range than now known. Specimens from adjacent Kentucky and liest Virginia have not been examined. They may also belong to this race.

Description:- Living specimens possess both types of guanophore spots on the dorsum. Small brassy flecks are very abundant and larger white spots are also present. On the sides and venter there are larger white or yellow spots.

The costal grooves usually number 20 , the trunk vertebrae 21 . Vomerine teeth range from 3 to 8 in a series. The largest specimen examined is $48 \mathrm{~mm}$. In snout-vent length. Sexual maturity is reached betreen 35 and $45 \mathrm{~mm}$. in snout-vent length.

\section{Plethodon richmondi nettingi Green}

Plethodon nettingi Green (1938: 295-9). Bishop (1943: 266-9). Grobman (1944: 313). Brooks (1945: 231). Brooks (1948: 239-44). Plethodon richmondi nettingi Green. Highton and Grobman (in press).

Type:- Cu 10279, an adult male, collected on Barton Knob, near Cheat Brldge, Randolph County, West Virginia, at an elevation af about 4000 feet, by M. Graham Netting, on June 29, 1935.

Diagnosis:- A race of Methodon richmondit that usually possesses 19 trunk vertebrae (rango 18-20).

Range:- Known from altitudes above 3500 feet in the Cheat Mountains of Randolph and Pocahontas Countios, West Virginia (figure II). 
Description:- In life, the dorsum of this form is similar in coloration to $\underline{P} . \underline{r}$. popei. The costal grooves usually number 18 , the trunk vertebra 19. Domerine teeth range from 3 to 8 in a series. The largest specimen examinge is $45 \mathrm{~mm}$. in snout-vent length. This form appears to have a smaller average size than the other races of richmondi. Sexugl maturity is reached at about $35 \mathrm{~mm}$. in snout-vent length.

\section{Plethodon cinereus Group}

\section{Plethodon dorsalis}

The range of $\underline{p}$. dorsalis centers in the Interior Low Plateaus Physiographic Province, but does not appear to be restricted to it, for records are available from several adjacent provinces. This species has not heretofore been recorded from Georgia, but specimens are now available from four different localities in that state, three of which are in the Piedmont Province. The southermmost record is frora Upson County (Unuz 85574), only a few miles above the Fall line. Other records are for Henry County (UF 8371 (3), UF 8L13 (3)); Cobb County (UG 206 (6); UG 275 (36)); and Dade County (FRA-MTN 22128 (12)). Probably the natural range of this form includes the western part of the state above the Fall Line.

The sympatric occurrence of this species with $\underline{P}$. cinereus in Georgia, Tennessee, Indiana, Illinois, and Oklahoma will be discussed. below. The two forms are very similar in appearance, and it is often difficult to identify individual specinens. For this reason a detailed study of the two species in the areas of overlap will be necessary be- 
fore it can be determined whether or not hybridization occurs.

In Georgla, where there is no overlap in the vertebral counts of the two species, it is impossible, on other grounds, to identify a small percentage of the available specimens. There are, however, several differences between the two species in Georgia that are apparent In a large majority of the avallable specimens. These include the shape of the mental gland in adult males; the zig-zag stripe of dorsalis, compared to the straight-edged stripe in cincreus; the presence of more red pigment in front of the eyes on the head of dorsalls; the great reduction in amount of melanophore pigmentation on the belly of dorsalis; and a similar reduction in red lipophore pigmentation on the belly of cinereus. The fact that there are a few exceptions to each of these specios characteristics might be considered evidence for hybridization were it not for the fact that occasional specimens of each species from localities in which the other form 18 absent show at least some of the same variations from the usual pattern. The fact that there is no tendency toward an increase in the number of trunk vertebrae in Georgia dorealis popula tions is also significant (see table IV). It may be seen from this table that there is no strong tendency for an increase in the number of vertebrae in samples of dorsalis that are from areas in which geographic overlap with cinereus occurs. We may conclude that there is, as yet, no good evidence for hybridization between the two species, but that more study is needed in all of the areas in wifch the two occur together.

There are no avallable records of dorsalis in southoastem Missouri. This region should be explored in order to determine whether or not dorsalls or angusticlavius are present. Smith (19L8: 1) has 
recently reported dorsalie from several locelities in southeastern IIlinois.

TABLE IV

THE NUUBER OF TRUNK VERTEBRAE IN SAIRLESOF PLETHODON DOLLALIS

Sample

Number of trunk vertebrae

$\begin{array}{lll}18 & 19 & 20\end{array}$

P. d. dorsalis

Georgietk

249

2

Alabama

2

Tennessee

Groat Smoky Mountains*

349

Van Buren County

144

6

Marion County

2

Indiana*

1

2

P. d. angusticlavius

Arkansas

23

5

Areas in which cinereus and dorsalis have been taken together at the same locality.

Junn (1926: 162) states that the unstriped phase in dorsalis is confined to adults and that this phase is much lighiter than the dark phase of cinereus. The latter part of his staternent appears to be tiue, but in a series of 31 living specimens of dorsalis from Van Buren County, Tennessee (UF 8394), there are five juveniles ( 16 to $18 \mathrm{~mm}$. snout-vent length) that are definitely of the dark phase. As in adults, there is 
a slight anount of red pisinent in the region of tho vack in which the stripe is located in reci-backed individuals, so that an outline of the irregular stripe can be seen when held at a certain angle to the Iight. The presence of the rod pigment, as woll as a reduction in the nelano phore pigmentation does give the lead-backed phase of dorsalis a lightor appearance than the corresponding phase of cinareus.

Grobman (1944: 308) presents evidence to show that Baird should be crediled with the authorship of the nane dorsalis. Under Article 21 of the Interrational farles of 7.oological Nonenclature as of 1944, he was correct. Since 194h, however, the fulles have been anended, so that Cope should now be recognized as responsible for this name.

\section{Plethocion dorsalis dorsalis Cope}

Plethodon cinereus dorsalis Cone (1889: 138-9). Blanchard (1926: 368-9). Bishop (1943: 236-9). Parker (1948: 22). Chermock (1952: 29). Plethodon ergthronotus (Green). Garman (1894: 38 ). Flethodon dorsalts Cope. Stejneger and Barbour (1917: 15). Dunn (1918: 460-2). Dunn (1926: 158-62). Mohr (1937: 40). Parker (1937:632 Paricer (1939: 75). King (1939: 550-1). Swenson (1939: 687). Grobman (1944: 308-11). Smath (1.94.8: 3.). Sinclatr (1950: 50). Mohr (1952: 59-60). Thurow (1955: 62-3). Holman (1955: 143).

Type:- USHR 3776, collected at Louisville, Jefferson County, Kentuclo.

Diagnosis:- An Esstem Srall Plethod on with the usual number of trunk vartebra 19 (range $18-20$ ), and a red dorsal stripe with trregular edges 
in the red-backed phase.

Range:- From southorn Illinois, Indiana, and southeastern ohio, south through Kenturky and Tennessee to northorn Alabama and northwestem Ceorgia (IIgure 22).

Description:- The dorsun of both color phases of $\underline{P}$. $\underline{\text {. dorsalis has }}$ small white spots $(0.2-0.4 \mathrm{~mm}$.) as well as smaller brassy flecks. The red-backed phase, in addition to the other pigments, contains a large emount of red lipophore pigment. All of these chromatophores appear to be identical with those of $\underline{P}$. cinereus. The mein difference between the two species is in the abundance and distribution of the pigments. The melanophore background in dorsalis is somewhat reduced, giving the animal an overall lighter appearance than cinereus. The melanophore pigment on the belly of dorsalis is greatly reduced with a corresponding increase in the amount of red lipophores, so that the belly appears to be nottled with red and white rather than black and white, as in cinereus. In dorsal1s there is a concentration of red pigment on the head in front of the eyes. The lateral guanophore pigment is of ten yellowish in color. The dorsal red stripe is quite variable. In some specimens the edges are irregular for the entire length of the body, while in others, they are irregular only in the enterior half or third of the body. The latter condition is especially common in Georgla specimens, and occasional specimens from Georgia have straight-edged dorsal stripes as in cinereus. Specimens with straight-edged dorsal stripes have been reported also from Indiana (Blanchard, 1926: 369) and Tennessce (Grobm $\operatorname{man}$, 1944: 309-10). 


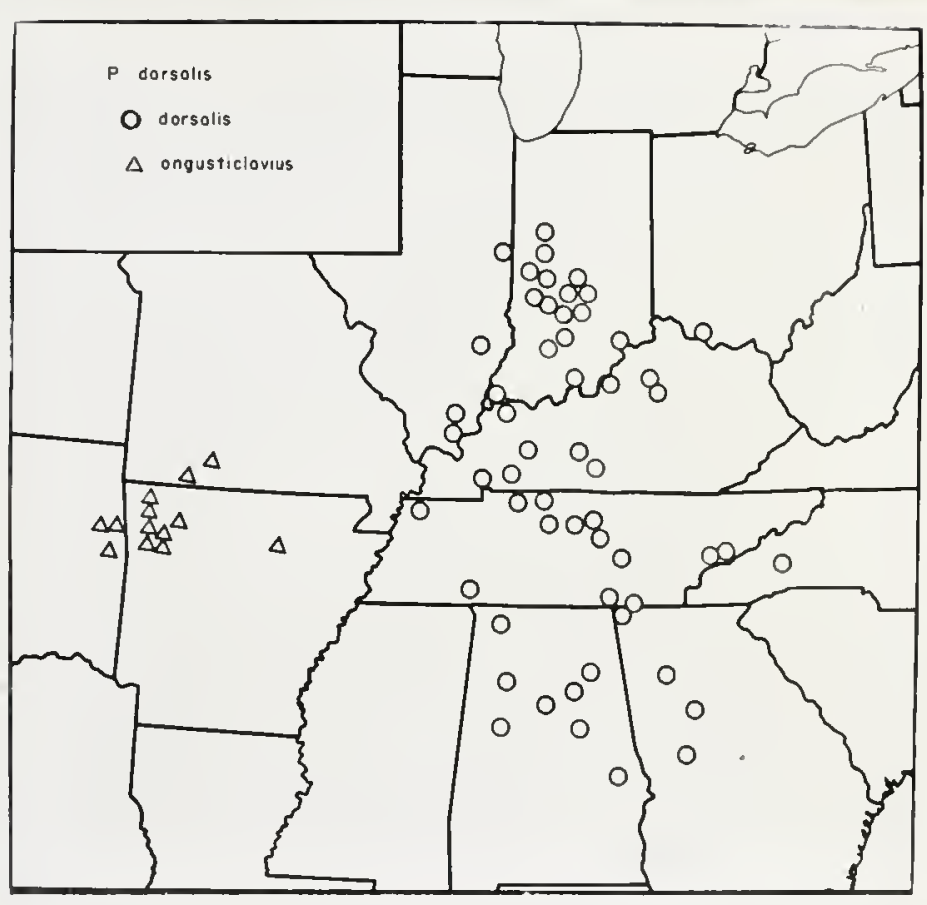

Figure 12. The distribution of the subspecies of Plethodon dorsalis. 
The costal grooves usually number 18, the trunk vertebrae 19. Vonerine teeth range from 3 to 6 in a series. This is a small species; sexual maturity is probably reached at about $30 \mathrm{~mm}$. In snoutvent length. The largest specimen examined is $4 \mathrm{~m}$. in snout-rent length.

\section{Plethodon dorsalis angusticlavius Grobman}

Plethodon cinereus angusticlavius Grobman (1944: 302). Dundee (1947: 117). Brage and Hudson (1951: 89). Bragg (1955: 27-8).

Type:- ANIH 40366, an adult male, collected at Nuj Cave, near Fairy Cave, Stone County, Missouri, by B. C. Marsha11, on October 1, 1927.

Diagnosis:- A race of Plethodon dorsalis in wich the width of the dorsal band is usually less than one-third of the width of the body.

Range:- Southwestern Missouri, northwestem Arkansas, and adjacent Oklam homa, north of the Arkansas River (figure 12).

Description:- living specimens of this form have not been exarined. of 33 preserved specimens (alI from Arkansas), 10 are of the striped phase: 11 show no trace of a stripe, and the remainder show only a faint stripe on the body, but at the base of tho tail, it widens and becomes mach nore well-defined. Typleally striped angusticlavius also possess a wider and brighter dorsal stripe at the base of the tall than on the body. The brightness of the stripe in this region appears to be due to a reduction in melanophore pigmentation in the dorsal stripe. The dorsal stripe is often irregular anteriorly, as in dorsalis.

The costal grooves usually number 18, the trunk vertebrae 19. Vomerine teeth range from 4 to 8 in a series. The largest specimen 
examined is $43 \mathrm{mra}$. in snout-vent length.

\section{Pletholion cinereus}

The red-backed salamander is the nost abundant terrestrial salanandor over most of its range, which includes much of eastern liorth America. Two distinct color phases are present, one with a prominent red or yellow dorsal stripe, the other uniformly dark in appearance. The frequency of these color phases varics from one locality to another. In some places, both phases occur in approximately equal numbers, in others, one type may be rare or absent. The proportional distribution of these color phases in the various populations has recently been studied by Thurow, and it is hoped that the results of his work will be published in the near future. Occasional specimens have been reported that lack the dark pigment and appear entirely red. One specinen from How Jersey lacked the red pigment in life and had a colorless dorsal stripe.

Plethodon dorsalis has been considered a subspecies of $\underline{P}$. cinereus by some workers (Cope, 1889: 138; Blanchard, 1926: 269; Bishop, 1943: 236), and as a distinct species by others (Dunn, 1926: 158; Grobwan, 1944: 308). Grobman points out that although the two forms are largely allopatric, at sone localities, especlally in southom Indiana, tho tro occur together, Grobnan examined the series of dorsalis that King (1939: 551) reported from the Great Smoky Hountains of Tennessee and confirmed their 1dentification. Specimens of both species found together at the same localities are reprosented in the GSMP collection. Theso localities are hite Oak Sinks (elevation 1750 feet) and the Sinks 
on the Little River (elevation 1600 feet). On the Tennessee side of the

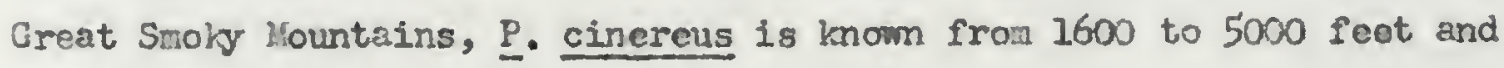
P. dorsalis from 1200 to 2200 feet.

The two species also occur sympatrically in the Pieimont of western Georgia. At two localities, 3.8 miles north or Honough, Henry County; and 8.5 rilles north of Thomaston, Upson County, the two species have been taken together. At. all other localities in westem Georgia,

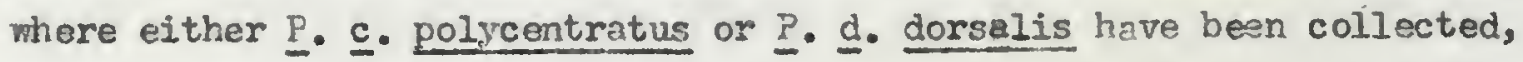
the other form has not been taken.

Bragg (1955:-27) reports that he collected a specimen of $\underline{P} \cdot \underline{c}$. serratus and a specimen of $\underline{P}$. d. angusticlavis at the same locality in Cherokee County, Oklahoma. Apparently the two species often occur to gether where their ranges overlap. Stith (1948: 1) published several new records of dorsalis from southeastem IIInois. $p$. cinereus and P. dorsalis probably also occur sympatrically in that state. There appears to be no evidence of intergradation at any of these localities, confiming the conclusion of Dunn and Grobman that dorsalis and cinereus have reached the species level of differentiation.

P. cinereus shows little apparent geographic variation over most of its range, except in the frequency of occurrence of the two color phases referre to earlier. Only in the Piecimont of Georgia and in Arkansas and Oklahoma, where the populations of this species have apparently become isolated from the parent stock, so we find differentiation of the magnitude required for the recognition of subspecies. The Arkansas and Oklahoma race (scrratus) possesses a dorsal band with 
serrations at each costal eroove. This characteristic is sometimes slightly developed in some specinens of other populations, but never reaches the frequency of occurrence or degree of development present in serratus.

The Georgia Pledmont subspecies (polycentratus) differs from other populations of cinereus in its increaged number of trunk vertebrae. Data on the number of trunk vertebrae in samiles of $\underline{P}$. cinereus are listed in table $\nabla$. It also diffors from most cinereus in possessing red plgment on the belly botween the front 1inbs. The cinereus populations in western North Carolina and eastern Tennessee are characterlaed by the complete absence of the dark lead-backed phase. P. C. polycentratus differs from these adjacent cinereus populations by the presence of the lead-backed phase (38\% of the type series of polycentratus are dark phase).

Sanders and Smith (1949: 28) report a specimen of Plethodon cinereus from Fern Lake, near Nacogdoches, Nacogdoches County, Texas. This specimen (OS 556) lacks the serrate edges in the dorsal stripe that are present in serratus, the nearest race geographically. It has 19 trunk vertebrae, but this number is not unusual in other populations of cinereus. Mr. Sanders, who collectel the specimen, informs me (In letter of November 12,1955$)$ that it was taken w1th a dip net from a bunch of fruiting sphagnum moss near the shore line, a most unusual habitat for this terrestrial species. It may represent an accidental Introduction by man, and the record needs confirmation by the collection of additional specinans from Texas before this state can be included in 
the natural range of this species.

\section{TABLE V}

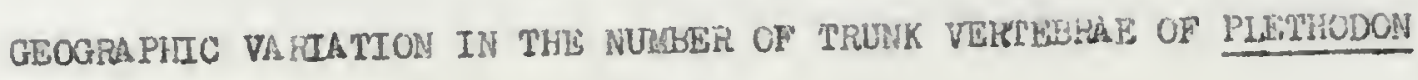
CIREREES

Locality

Number of trunk vertebrae

$\begin{array}{llll}19 & 20 & 21 & 22\end{array}$

23

$\underline{\text { P. }}$.

New Brunswick, Canada

Nova Scotia, Canada

Quebec, Canada

Indiana

Missouri

New Jersey

Virginia (Blue Ridge Province)

Eastern Tennessee and western lorth Carolina

$3 \quad 14 \quad 1$

$2 \quad 21$

11

62

1

7

$\begin{array}{lll}7 & 33 & 3\end{array}$

5409

P. E. serratus

Arkansas

$3 \quad 29$

P. c. polycentratus

Georgia

$21 \quad 24$ 
Plethodon cinercus cinereus (Groen)

Salamandra cinerea Green (1818: 356$)$.

Salamandra erythronota Green (1818: 356). (Type locality, probaily vicinity of Princeton, New Jersey.)

Plethodon cinereus (Green). Tschudi (1838:58). Dunn (1926: 163-80). Sauropsis ervthronotus (Green). Fitzinger (1843: 33).

Plethodon erythronotus (Green). Baird (1850: 285).

Ambystoma erythronotum (Green). Gray (1850: 37 ).

Salamandra puncticulata Valenciennes in Duneril and Bibron (1854:87). Salamandra agilis Sager (1858: L29). (Type locality, Detrolt, Michigan) Plethodon exythronotus cinereus (Green). Cope (1869: 99). Plethodon cinereus cinereus (Green). Davis and Rice (1833: 26). Bishop (1941: 196-219). Bishop (1943: 232-6). Grobman (1944: 300-2). Plethodon cinereus erythronotus (Green). Cope (1889: 135). Plethodion huldae Grobman (1949: 136). (Type locality, liawisbill Hountain, Madison County, Virginia.)

Type:- Tunn (1926: 165) states that the type is not know to exist. The type locality is probably in the vicinity of Princeton, New Jersey.

Diagnosis:- A Smell Eestern Plethodon with a black and white mottled belly; usually with 20 trunik vertebrae; and a straight-bordered dorsal stripe in the red-backed phase.

Range:- Nova Scotia, New Brunswick, southem Quebec and Ontario, Canada; south through the eastern United States to North Carolina, eastern Tennessee and Kentucky, Ohio, Indiana, Illinois and southeastem kissouri (figure 13). 


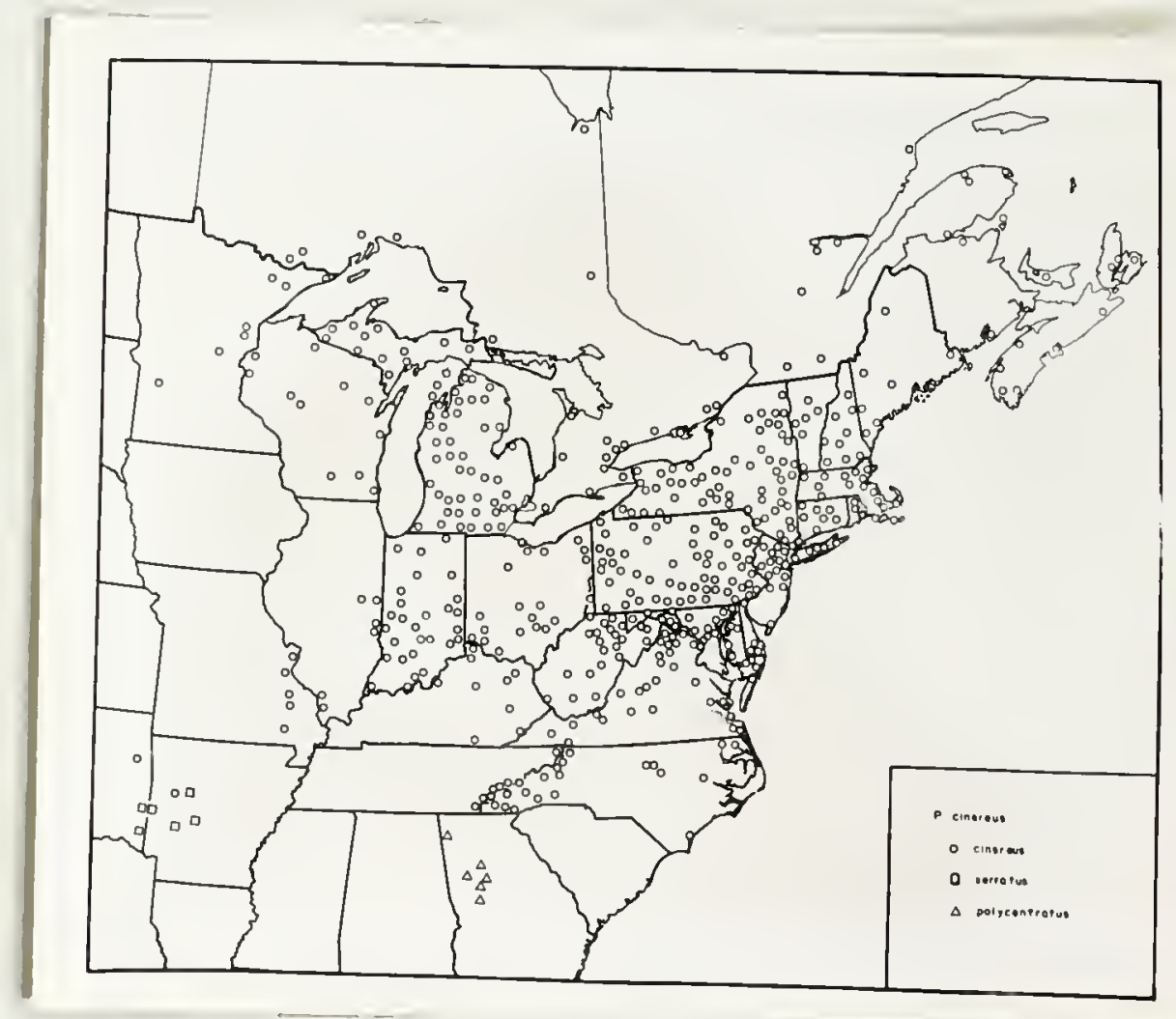

Figure 13. The distribution of the subspecies of plethodon cinereus. 
Description:- The dark, unstriped phase is usually characterized by the absence of red lipophores, the prosence of sisall wite spots on the dorsum (0.07-0.2 mm in dianeter), and numerous sianler brassy flocks on the head, back, and tail. The belly is mottled with black and yeilow or whive granophores. The lateral guanophore pigment is ginilar to that on the beliy.

The reri-backed phase has sides and belly similar to the dark phase. The white spots and brassy flecks on the dorsum are reduced in the area of the dorsal stripe, but are present on the head and tall. The coior of the lipophores in the dorsal stripe is variable, ranging from red to yellow.

The costal grooves usually number 19, the trunk vertebrae 20 . Vomerine teeth range from 3 to 9 in a series. The largest specimen examined is $51 \mathrm{~mm}$. In snout-vent length. Sexual maturity is reached at about $35 \mathrm{~mm}$. in snout-vent Iength.

\section{Plethodon cinereus serratus Grobman}

Plethodon cinereus serratus Grobman (1944: 306-8). Bragg (1952: 2l44). Brogg (1955: 27-8).

Type:- CNH 39464, a female, collectes on Rich Mountain, Polk County, Arkansas, at an elevation of 2500 feet, by Karl P. Schmidt and C. W. Barter, on Warch 23, 1938.

Diagnosis:- A race of Plethodon cinereus In which the edges of the dorsal stripe are serratod at each costal groove. 
Range:- West-central uplands of Arikansas and adjacent Oklahoma, south of the Arkansas itiver (figure 13). Also reported by Bragg (1955: 27-8) from Cherokee County, Oklahoma (north of the Arkansas River).

Description:- The dark phase is apparently rare in tris form, only one of 33 spectmens examinea lacked the red dorsal band. In rec-backed individuals, the serrations on the edges of the dorsal stripe are present on the body, but not on the tail. The serrations are due to the fact that the red plement in the dorsal stripe extends ventrolaterally toward the tcp of each costal furrow. The usual absence of melanophores in this extension of the dorsal stripe makes the saw-tooth edge of the stripe conspicuous to the naked eye.

The costal grooves usually number 19, the trunk vertebrae 20. Vomerine teeth range from 3 to 8 in a series. The largest specimen examined is 46 m. In snout-rent length.

Plethodon cinereus polycentratus Highton and Grobman Elethodon cinereus polycentratus Highton and Grobmen (in press).

Pype:- UF 8376, an adult male, collected 2 miles northeast of Palnetto, Fulton County, Georgia, by Albert H. Highton and Richard Highton, on February 2, 1954.

Diagnosis:- A race of Plethodon cinereus in which the usual number of trunk vertebrae is 21 or 22 (rarely 23 ).

Pange:- The Pledmont of western Georgia (figure 13).

Description:- This race is similar in coloration to the typical sub- 
species. It differs in possesstng a grester number of bady segments. Vomerine teeth range from 3 to 7 in a series. The lergest specimen is $42 \mathrm{~mm}$. in snmat-vent length. Sexual arturity is rached at about 35 rum. in snout-vent length.

\section{The Eastern Large Plethodons}

This group, as defined by Grobman (1944: 256) on the bests of larger size and fewer costal grooves than the other oastem plethodons, includes six species that inhabit the sastern portion of the United States. Pletrodon glutinosus is the most widely distributed and all the other suecies occur within its range. F. yonehiossee occurs in the Southem Section of the Blue fligge Province north of the French Brmad River. P. ouachitae, superficially very simtlar to yonahlosseo, lives in the Ouachite Sountains of Arkansas and Oklahoma. The ro centry cescribed $\underline{P}$. caddoensis is known only from the Caddo Mountains ca Aricassas. P. jinrdani includes elght subspecies, all occurring in the Southem Section of the Blue lidge Frovince. The range of $\underline{p}$. wehrlei is centered in the inglaciated Allegheny Plateau Section of the of the Appalachian Plateaus Province. (See Grobman (194/1) for an analysis of the distribution of these forms.) Two recently doscribed species, P. dixi and $\underline{P}$. jacksomi are here considered races of wehrlet, because of their close morplological similarity to rehrlei and the fact that they rep?ace wehrlet geographically.

There has been much speculation on the relationships of the species within this section of the genus. Dunn (1926: 23) believes this to be the most primitive group of the genus, with yonahlossee the 
most primitive form. Dunn and Grobman (194:4: 276) both believe the relationship between yonahlosses and wehrlei is close. Hairston and Pope (1948) suggest that yonahlossee is closely related to jordani and that close sinilarity between some jordani and glutinosus is merely convergence, but others think that the closest relative of jordani is glutinosus. Bishop (19hI) even considered one race of jordand (shermani) to be racialiy related to glutinosus. On the other hand, Grobman (194h) believed that fordani and closely related forms (now all considered races of jordani) are different enough to warrant the erection of a separate group, that he called the motcalfi group, distinct from all the other kastern Large Plethodons.

Characters studied by previous workers in attempting to determine the morphological similarity and hence the relationships of these forms, include size, number of vomerine teeth, number of costal grooves, degree of sexual dimorphism, and pigmentation. In the present study, most of these charecters have been recxamined using large series of specimens that, for the most part, were not available to previous workers. Several characters have been found to be extremely variable and not diagnostic of any one form. For example, Bishop (19lil: 18), Grobman (1944: 287), and Hairston and Popo (1948: 274) all believed that the Plethodon fordani group has fewer vomerine teoth than $\underline{P}$. glutinosus. I have counted the vomerine teeth of 269 Florida glutinosus (figure 14), 125 Virginia glutinosus (the same specimens used by Pope and Pope, 1949, in their study, and our counts essentially agree), 45 glutinosus from the Coastal Plain of Virginia and North Carolina (figure 15), 115 specinens of $\underline{P} \cdot \underline{1}$. jordani (figure 16), 27 specimens of $\underline{P} \cdot \mathbf{1}$. shermani, 72 specimens of $\underline{P} \cdot \underline{1}$. netcalfi, 53 specimens of $\underline{P} \cdot \underline{j}$. mela- 
ventris, I4 specimens of $\underline{P} \cdot \underline{j}$. rabunensis, 29 specimens of $\underline{\underline{P}} \cdot \underline{j}$. teyahalee, and 44 specimens of P. 3. unicol. For a given size, the range of veriation is quite siailar for each form, although there is often a statistically significant difference in the variability and/or the ontogenetic rate of change in the different species. The data of Popo and Pope (1951) indicate that $\underline{P}$. ouachitae has a similar range of variation in number of teeth as plutinosus and jordani, although the avm erage number of teeth is slightly higher. The number of teeth in 60 P. wehrlei (figure 17) seens to be less than in the above forms, while Pope (1950) shows that $\underline{P}$. yonahlossee than the above forms. 39 P. caddoensis, although small in size, have even more teeth than $\underline{P}$. yonahlossee of the same size range (figure 18). Except betrecn adult wehrlei and yonahlossee, or wehrlet and caddoensis, there is consider able overlap in the vonerine tooth counts of all the Eastem Large Plethodons, and even in the case of these, only adults can actually be distinguished on the basis of this character. It is true that large series of adults of species that differ greatly in sizo (e.g. P. E. glutinosus and $\underline{P} . \underline{j}$. Metcalfi) will differ in average number of vomerlne teeth, but this is mainly a reflection of the difference in size between the two forms. This character obviously cannot bo used as an aid in identification, since specinens of the two species that are the same size will have similar vomerine tooth counts.

Several other supposed differences mentioned in the ilterature are not useful in deternining relationships. All, except $\underline{P}$. mehrlei, have a similar number of costal grooves (see table VI). Sexual dimorphism in size is present in several forms that have been critically studied. The type of lateral guanophore pigmentation varies 


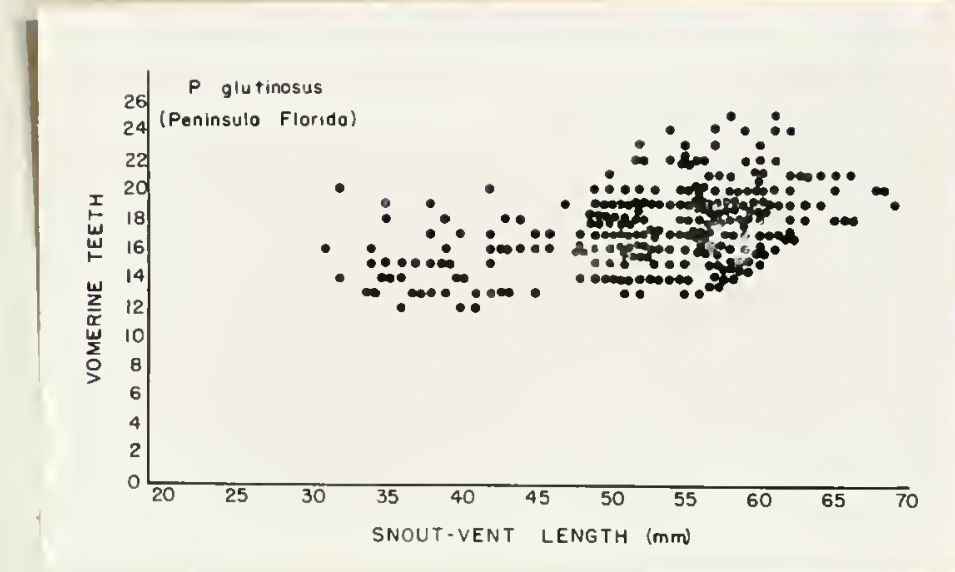

Miguro ل ل. Vomerine teeth of 269 peninsula Florida P. glutinosus plotted against snout-vent length.

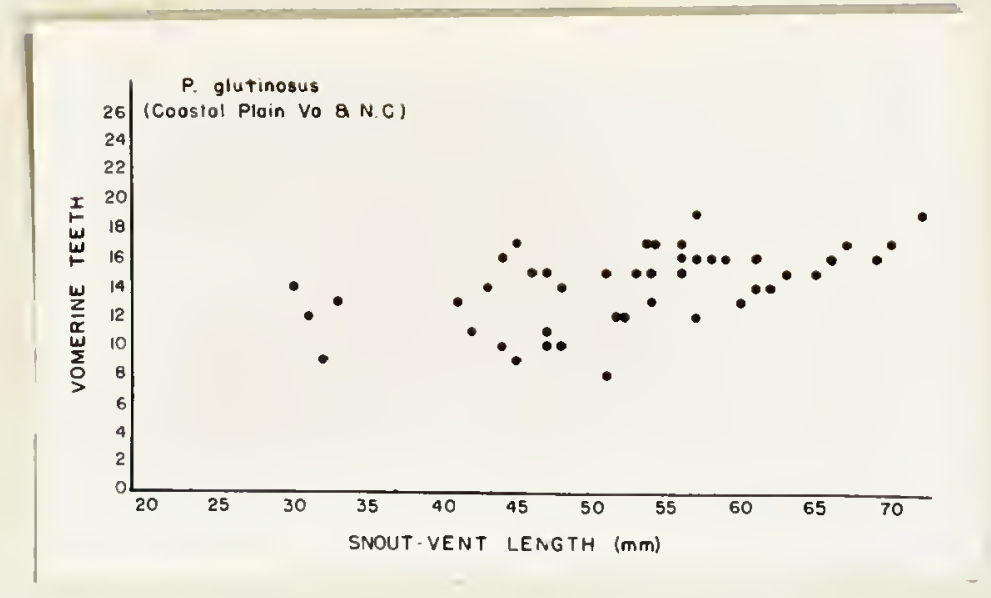

Figure 15. Vomerine teeth of $45 \mathrm{P}$. glutinosus from the Coastal Plain of Virginia and North Carvlina plotted against snout-vent length. 


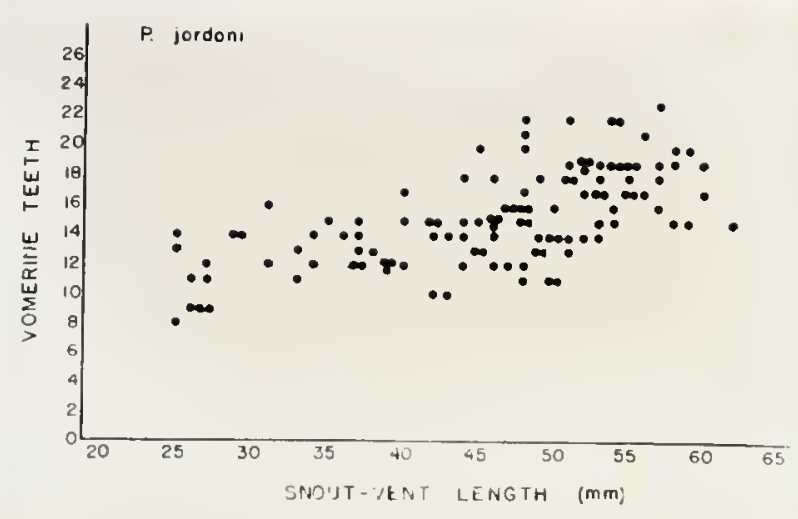

Figure 16. Vomerine teeth of 115 P. 1. jordani plotted ageinst snoutvent length.

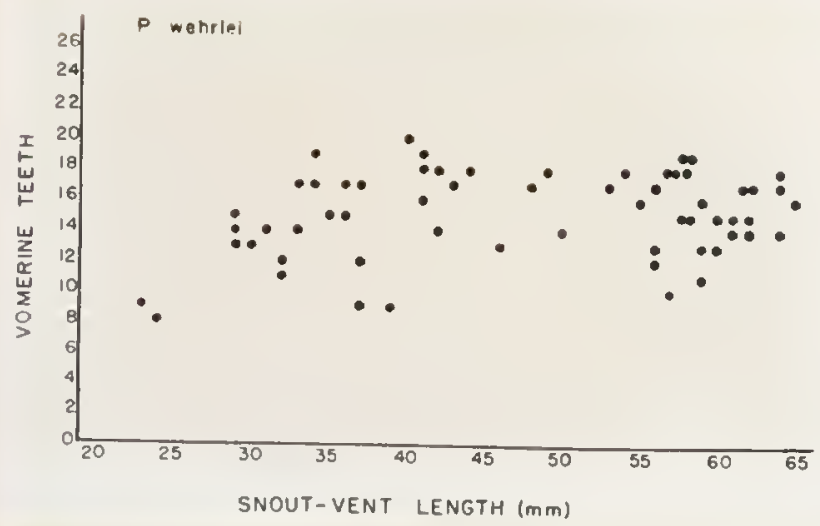

Figure 17. Vomerine teeth of $60 \mathrm{P}$. w. wehrlei plotted against snoutvent length. 


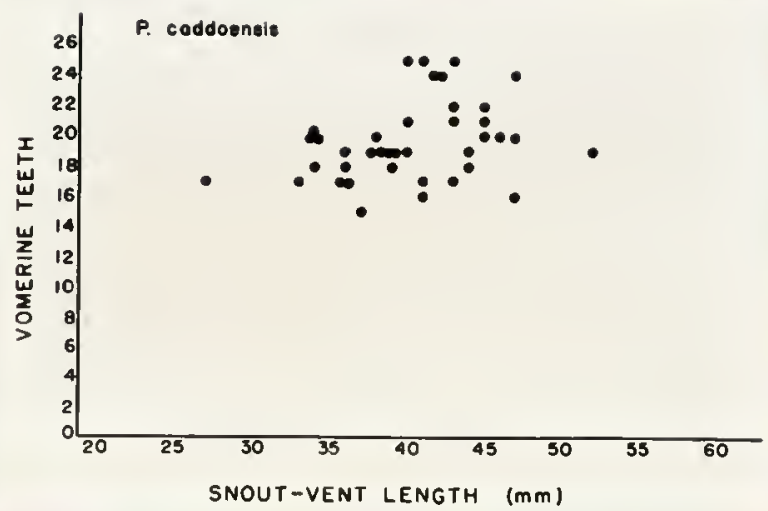

Figure 18. Tomerine tecth of 39 P. caddoensis plotted against snoutvent length.

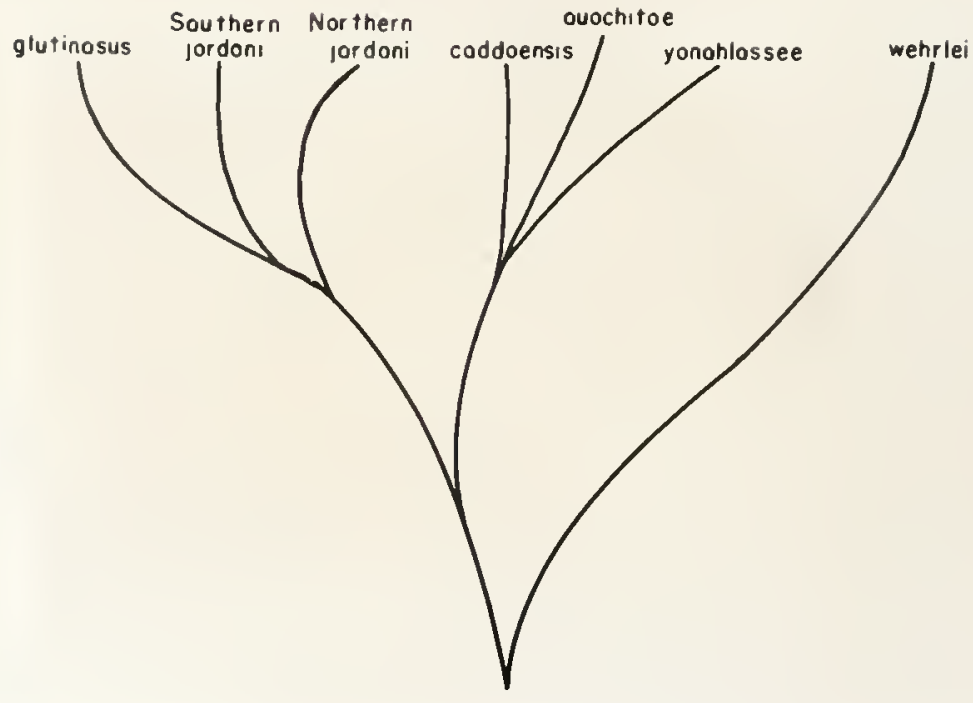

Figure 19. Suggester phylogeny of the Eastern Large Plethodons. 
somewhat within a species (both individually and geographically), but there appear to be no consistant differences between species.

There remain, then, only a few characters that can be used to diagnose or distinguish the Eastern Large Plethodons. Erch species is sympatric with, and oftan coexists in the same r.abltat with one or more of the other species without any evidence of interbreeding. As far as we know, each is a genotically distinct unit, and there is much evidence to indicate that different specles have different ecological requirements. Yet preserved specimens that have lost their pigmentam tion characters are often oxtremely difficult to ldentify because of the morpholog:cal similarlty of most of these salamanders.

P. wehrlei is distinguished on the basis of a greater anount of webbing on the toss, by having an average of one more trunk vertebra, and by possessing fever vomerine teeth than the other spocies. P. yonahlossee may be recognized by its distinctive color pattern in Iife. It also differs from the others (except caddoensis) in possessing a greater number of vomerine teeth. P. ouschitae has a similar color pattern to that of yonahlossee, but it has fewer vomerine teeth. I have found no cheracter that will consistantly separate glutinosus and fordani. The chin of glutinosus is usually darker than that of jordani, but certain populations of both species more closely resemblo the other (soroe Texas glutinosus have very light chins, whereas $\underline{P} \cdot \underline{\mathcal{1}}$. teyahalee and some $\underline{P} \cdot \underline{j}$ rabunensis possess dark chins). The close morphological similarity between all the foris, except I. wehrlei, Indicate that they are a closely related group of species, with only wehrlei separated from the others by a number of characteristics. 
TABLE VI

THE NURBER OF COSIAL GROCVES AND VFRTEBRAE IN TIIE EASTERN LARGE PJETHODONS

\begin{tabular}{|c|c|c|c|c|c|c|c|}
\hline \multirow{2}{*}{ Form } & \multirow[t]{2}{*}{ No. } & of costal & \multirow{2}{*}{$\begin{array}{l}\text { Erooves } \\
17\end{array}$} & \multirow{2}{*}{$\begin{array}{c}\text { No. of } \\
16\end{array}$} & \multirow{2}{*}{$\begin{array}{l}\text { trunk } \\
17\end{array}$} & \multicolumn{2}{|c|}{ vertebrae } \\
\hline & & 16 & & & & 18 & 19 \\
\hline P. w. wehrlei ${ }^{l}$ & & 3 & 57 & & 2 & 48 & \\
\hline P. w. dixd & & & & & & 30 & 4 \\
\hline P. yonahlossce & & & & & 12 & 2 & \\
\hline P. ouachitac & & & & & 16 & & \\
\hline P. ciddoensis & & & & & 35 & 2 & \\
\hline P. glutinosus ${ }^{2}$ & 32 & 319 & 14 & 19 & 212 & 15 & \\
\hline P. j. jordani & 11 & 68 & 3 & & 8 & 1 & \\
\hline P. j. metcalfi & 10 & 78 & 2 & & & & \\
\hline P. j. shermani & 6 & 64 & 3 & & 1 & & \\
\hline P. j. unicoi & 4. & 56 & 1 & & 1 & & \\
\hline P. j. melaventris & 5 & 67 & & & & & \\
\hline P. 3. rabunensis & 1 & 39 & & & 6 & & \\
\hline P. 3. teyahalee & 2 & 24 & 4 & & & & \\
\hline
\end{tabular}

1

This is the only fom in the table in which the same specimens were used to count both costal grooves and trunk vertebrae. The data on both char acteristics are included only to show the close correspondence between the two counts. lio other speciman of any of the forms Ilsted in the table was included under both costal grooves and trunk vertebrae.

2

For a geographic breakdown of these counts, see table VII. 
Tho young of yonahlosgee, some wehrlei, and two races of jordani are known to possess dorsal red spots. These disappear in adult Wehrle1 (except P. W. jachsoni) and jordani, and become incorporated into the dorsal red stripe of vonahlossee. Ho information is yet available on the very small young of ouachitae, caddoensis, and several of the races of jordani, but young ourchitae may possess than (see Pope and Pope, 1951: 145). The red dorsal spots appoir to be definitely absent in the young of glutinosus. Red pigment was absent in all of the newly hatched young I have exanined from Florida (Highton, in press), as well as in very young specimens from many other localities. Dunn (1926: 139) records a specinen of . glutinosus fron Clayton, Ceorgia, that had tiny paired red dorsal spots, but this may vell be a specimen of P. I. shermani, known to occur within $10 \mathrm{miles}$ of clayton. Cope (1889: 141) also records young specinens of glutinosus from caves in Lontgonery County, Virginia, possessing these spots, but the specimens were probably $\underline{P}$. I. jacksoni.

A reduction in the anount of melanophore pigmentation on the chin occurs in yonahlossee, ouachitae, caddoensis, wehrlei, most races of fordani (except teyahalee and some rabunensis) and in somo Texas elutinosus (albapula).

Lost species possess a dark bolly, but the four northern races of jordani (jordani, shermani, unicoi, and cspecially metcalfi) are light-bellied, as aro sone southern wehrlci.

P. Yonahlossec and P. Elutinosus (except for its southeastern Coastal Plain represcntatives) attain a larger maximun sizo than tho 
other species. $\underline{p}$ - caddoensts appears to be the smallest Lastem Large Plethodon. P. 1. motcalfi might also be considered a dwarfed form.

Red pigment occurs in adult jacksoni, yonahlossee, ouachitre, jordani, and shemani. Dorsal guanophores occur in glutinosus, albagula, ouachitae, caddoensis, clemsonae, and teyahalee. Lateral guanophores are usually present in all Large Eastern Plethodons, except for four races of jordani (jordani, metcalii, melaventris, and some shermani).

In summary, P. whrlei seems to be the most distinct of the Eastern Large Plethodons, while the others seen to be morphologically very similar to each other. In wy opinion, the hypothetical ancestor of the group might nost reasonably be assumed to have boen a moderatom sized animal with a light chin and drirk belly, probably with paired red spots on the dorsum of the aduit, possessing 17 trunk vertebrae, a short vomerine series, and webked toes. P. wehrlei is closest to this hypothetical ancestor, although its body has becone slightly elongatod with the addition of an extra trunk vertebra. The chin is still light in all except glutinosus (albagula excepted) and one or two races of jordani. The dark belly has remained in a.ll but the four northem races of jordani and in southern wehrlei. A larger size has been attained by yonahlossee and glutinosus, while dwarfing has occurred in northerm jordani (especially metcalfi) and caddoensis. P. Yonahlossee has a much longer vonerine series than the others. The degree of relationship indicated by a study of these characters would seem to indicate a phylogeny as outlined in rigure 19. 


\section{Plethodon rehrlai Group}

\section{Plethodon wohrlei}

Plethodon vehrle1 inhabits the unglaclated Appalachian Plam teaus Province in southwestern New York, rostem Pennsylvania, extrene southeastern Ohio, West Virginie, and adjacent Virginia (whore it occurs a short distance outsice the Appalachian Plateaus Province). This species is the most distinct of the stern large Plethodons and appears to occupy a somewhat isolated position in the Eroup, differing from the other species in several respects. There is usually more webbing on the toes of this species, although occesional specimens of other species, especially P. cadrioensis and P. ouachitae, approach E. wehrlei in this regard. $\underline{P}$. wehrlei is the only Eastern Iarge Plethooion that normally has 18 trunk vertcbrae; all the others usually possess 17. P. wehrlei possesses rewer vomerine teeth than any other Eastern large Plethodon and it is the only species thet has melenophore pigmentation in the peritoneum.

Two close relatives of Plethodon wehrlei from southwestem Virginia ( . dixi and $\underline{P}$. jacksoni) have recently been described as distinct species by Pope and Fowler (1949) and Newnan (1954), P. dixi appears to differ from $\mathrm{P}$. wehrlei only in proportions and pigmentation. It rould seen best to regard it as a subspecies of $\underline{P}$. wehrloi, since it replaces the latter geographically. P. jacksoni, based on specimens from an adjacent county, less than 15 miles frosu the dixl localities, essentially differs from $P$. vehrlod in the retention of the juvenile dorsal red spots in the adult. Young West Virginia wehrlei often possess these spots, but they appear to be absent in more northern wehrlei. 
Since jacksont does not otherwise differ from some wehrlei and dixi, it is also here regarded as a subspecies of $P$. wehrlet.

Several writers have comented on the geographic variation in $\mathrm{P}$. wehrlei. Netting (1936: 91) lists ways in which West Virginia P. wehrlei differ from topotypic Pennsylvanta specimens. The formar possess white spotting on the throat and chest, while in Pennsylvania specimens the white spotting is absent. The lateral whito pigment is also more abundent in West Virginia material.

Dunn (1926: 135) mentions the presence of paired red spots on the dorsum of a juvenile from Bristol, West Virginia. Brooks (1945: 231) reports that three adults, as well as most of the juveniles, in a series of 22 specimens from Randolph County, West Virginia, also possess dorsal red pignent. Bishop (1941: 238) states that none of the specimens of this species he has examined (presumably all from Hew York and Pennsylvania) have shown the slightest trace of red pigment.

Grobman (1944: 287) has pointed out somo of the above differences between West Virginia and New York and Pennsylvania specirens, and has also suggested that southem wehrlel may attain a greater size than northern specimens. In view of these differences in northern and southern P. W. vehrlei, this form should be further studied for other evidences of geographic variation. It is possible that the northern and southern populations should be recognized as distinct subspecies. In the possession of reduced black pigmentation on the anterior portion of the belly, southern wehrlet are more similar to dixd and jacksonf than are northern wehrlei. In the presence of red spots on juveniles, as well as in some ackits, West Virginia specimens are similar to 
jacksoni. The increased lateral white pigmentation in southern wehrlei 1s also paralleled by jacksont and dixi.

I have not carefully examined the pigmentation of any of the races of wehrlei in life, although a casual examination of living spec1mens from New York, West Virginia, and Virginia (dixi topotypes) was made before the present study was contemplated. A comparison of the geographic variation in pigmentation characters within the species, as well as with other Plethodons is much to be desired. Fope and Fowler (1949: 1) state that both "bronzy mottling" and "swall light mecks" are present on tho back of dixi. The former disappear rapidly in preservatives whereas the latter remain, although fading somewhat. Pope and Fowler state that they have occasionally observed the "white IleckIng" In wehrlel, but never the "bronzy mottling." The vitite flecking is probably the same type of spot evident on the specimen figured by Bishop (19lia: fig. 45). The red dorsal spots, present in young West Virginia wehrlel, were not observed by Pope and Fowler in a large series of paratypic dixi, including 59 juventles. The belly of did is mottled (prosumably wth white guanophores on a relanophore background), whereas the belly of wehrlei is usually uniformly pigmented with melanophores. In slze, dixd appears to bo smaller than the other races. The specimens of dixd that have been examined also appear to have proportionately narrover heads and slenderer bodies than wehrlel.

Newman (1954: 12) states that the dorsun of jacksons has "white rlocks" and "silvery mottling," the latter usually disappearing within twenty-four hours after preservation. Wottling on the belly is also present, as in dixi. According to Newman, the dark belly pigmentation 
fades in preservatives. Since some adult wehrlei from West Virginia have been reported with red spots on the dorsum, it may be found that these wehrlet and jacksoni are very similar, if not the samo form. If this were the case, the name jacksoni would be available for southern wehrlei, should the latter be shown to be a distinct subspecies (see above).

A search should be mede for $\underline{P}$. W. dixi in southwestern Vin ginia, for It is very unlikoly that it is restricted to the vicinity of two caves only two miles apart. Populations from other localities wil]. be imortant in determining the amount of variation in the form, as well as its relationships with jacksoni and vehrlei.

Plethodon wehrle1 wehrles Fowler and Dunn Plethodon wehrle1 Fowler and Irunn (1917: 23-4). Dunn (1926: 133-6). Eishop (1927: 177-8). Hassler (1932: 95-6). Walker (1933: 224). Netting (1936: 89-93). Hetting (1936: 28-30). Bishop (19l12: 232-9). Lachner (19l42: 263). Bishop (1943: 281-4). Grobran (19l4: 285-7). Frooks (1945: 231). Notting (1946: 12). Netting, Green, and Pichmond (1946: 157-60). Brooks (1948: 244). Grobman (1949: 136). Newman (1954: 13).

Type:- ANSP 19123, collocted at Tro Lick Hills, Indiana County, Ponnsylvania, in September, 1911, by R. W. Mehrle.

Diagnosis:- An Eastern Larse Plethodon with webbing between the toes on the hind foot often extending to the joint between the Pirst and second phalanges; 18 trunk vertebrae; and a lower number of vomerine teeth (4II in a single serles) than in other Eastern Large Plethodons. Dorsal 
rod pigment is uoually absent in adults, and wite pigment is usually absent from the belly, except on the chin and between the anterlor limbs.

Range:- Frou Allegany State Park, Cattaraugus County, New York, south In the Allegheny Plateau Section of the Appalachian Plateaus Province through western Pennsylvania and West Virginia, except for the southwestem portion of the latter state (figure 20). Also recorded from Honroe and Washington Countios, Ohio, by Walker (1933: 22h), and from the Valley and Ridge Province of Highland County, Virginia, by Netting, Green, and Richmond $(1946: 157)$. A specinen from the Blue Ridge Physlographic Frovince of Nelson County, Virginia, is questionably referred to this species by Grobman (1949: 136).

Description:- The pigmentation of this form has not been studiod in iffe. Several writers have mentioned that this species is brown or bluish in appearance, probably an indication of a reduction in the intensity of melanophore pigmentation, as often occurs in the Fastem Small Plethodons. (The distinction between two types of guanophores on the dorsur given in the orlgtnal descriptions of dixi and jacksonf are 2130 reminiscent of tho Eastern Small Plothodons.) Iateral guanophore spots are present on the slcles, as well as on the chin of southern wehrie1. The young and occasional adurts from Vest Virginia possess paired red dorsal spots (Brooks, 1945: 231).

The costal grooves usually number 17 , the trunk vertobrae, 18. Vomerine teeth range from 4 to 11 in a series. This form is moderate in size, the largest specirans are about $70 \mathrm{~mm}$. in snout-vent length. 


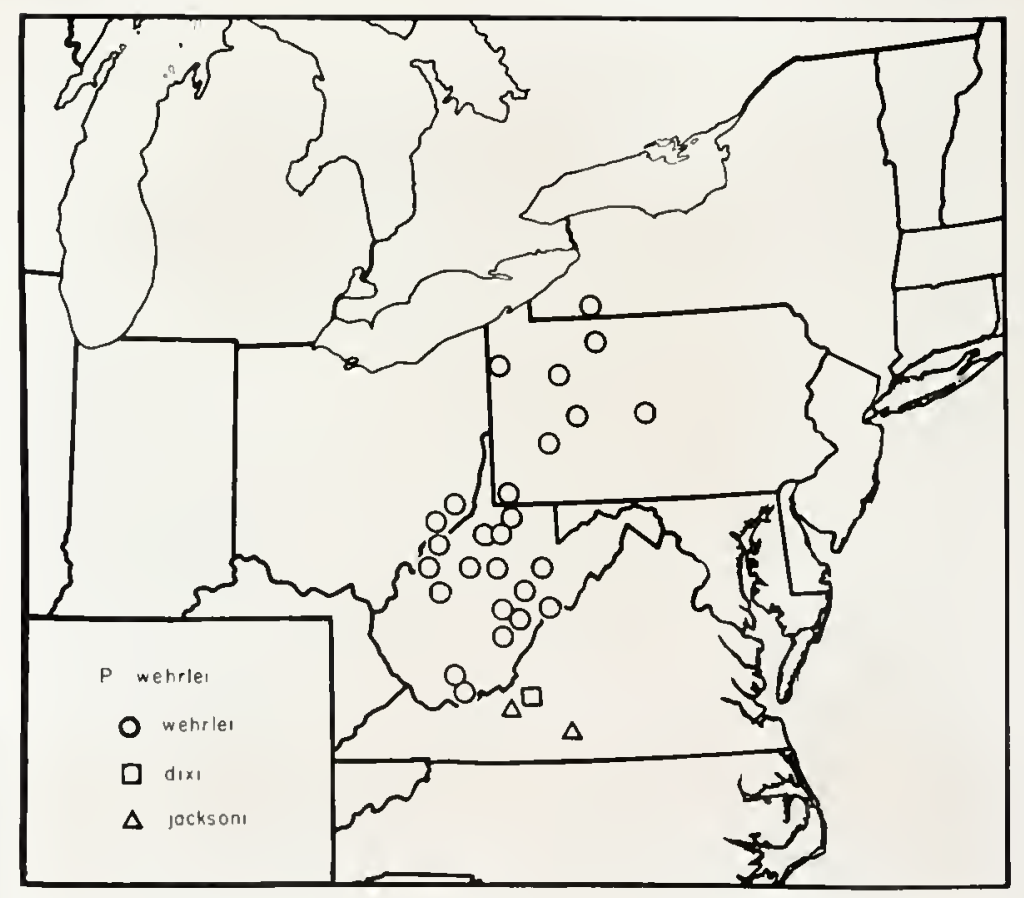

Figure 20. The distribution of the subspecios of Plethodion wehrlet. 
Plethodon wehrlei dire Pope and Forier

Plethodon díxi Pope and Fowler (1949: 1-4). Fowler (1951: 147-8).

Iype:- CNuir 56510, a male, collected at Dixde Caverns, Roanoke County, virginta, on July 11,1948 , at an altitude of 1170 feet, by Jom $w^{\circ}$ Funkhouser, Sarah H. Fopo, Clifford H. Pope, llallowell Fopo, and Mitney Pope.

Diagnosis:- Similar to P. W. wohrlei, except for slightly szaller size, slenderer head and body, the presence of white guanophore mottling on the belly, and small brassy flecks on the dorsum.

Pange:- Inom only from Dixic Caverns, New Dixile Cavems (about 410 jards from Dixie Cavems), and Blankenship Cave (about 2.4 miles east of Dixie Caverns), in western Roanoke County, Virginia (figure 20).

Description:- For a description of the type serios in life, see Pope and Fowler (1949).

The costal grooves usually number 17 , the trunk vertebrae, 18 . Vomerine teeth range from 4 to 9 in a sories. The largest specinen measured by Pope and Fowler was 57 min. In snout-vent langth.

\section{Plethodon wehrlet jacksont Nemman}

Plethodon jacksoni Nerman (1954: 9-14).

Typo:- An adult male, collected at Trllilum Vale, about 1 mile asst of Blacksburg, Wontgomery County, Virginia, at an elevation of 2100 feet, on February 11, 1950, by Walter B. Newran. 
Diagnosis:- Sinilar to P. W. wehried, except that the juvenile color ation, paried red dorsal spots, is retained in the adult.

Range:- Knom from the vicinity of BlacksburE, Montgomery County, Vir ginia, and Smith lountain Gorge, Mittsylvania county, Virginia (figure 20). The Iatter record extends the range of Plethodon wehrlei into the Fiednont Physiographic Province.

Description:- Specimens of this form have not been examined and no information other than that published in the original description is avilable.

\section{Plethodon yonahlossee Group}

INost previous workers have belleved that this group is very closely related to $\underline{P}$. wehrlei and it has even been suggested (Grobman, 19lili: 276) that yonahlossee and wehrlel may evontually be shorn to be subspecifically related. For reasons given above, it is suggested here that the yonahlossee group is actually more closely related to the gutinosug group than aither is to the wohrlei group. The three species included in the yonahlossee group, yonahlossee, ouachitae, and caddoensis, appear to differ from the glutinosus group mainly in pigmentation characters. There are no other known consistant differences between the twa groups, although there is variation in size and other characters within each group.

The disjunction in the ranges of the species of this group suggests that the prototype was once widely distributed in the eastern United States, and that due to subsequent environmental changes, the 
three populations have becone isolated. In external appearance, at least, yonahlossee is quite similar to ouachitae. P. caddoensis, occupsing an area adjacent to ouschitae, appears quite distinct from both ouachitae and yonahlossee. This would seem to indicate that the two species, caddoensis and ouachitae, have been undorgoing differentiation west of the ilississipji River for quite some time. Fope and Popo (1951) have suggested that there may be two other undescribed forias of this group in OkIahoma and Arikansas.

P. yonahlossee is rost abundant at intermediate altitudes in the southern Appslachians, being rare or absent in the northern-type spruce-fir forests as well as at low altitudes below 2500 feet (Pope, 1951: 81). In Arkansas and Oklahoma, P. ouachitae is known from 1700 to 2800 feet on Rich Mountain, while P. caddoensis has been taken at lower elevations, from 950 to 1200 feet. Both $\underline{P}$. ouachitae and $\underline{P}$. yonahlossee occur in abundance at localities where $\underline{p}$. glutinosus is also present, so 1t wolld appoar that the two are able to coexist with P. glutinosus under certain conditions. It would therefore seem most Iikely that factors other than competition with glutinosus are responsible for the absence of the $\underline{P}$. yomahlosseo Eroup at lower altitudes in the eastern United States. Possibly the higher terperatures axdsting at lower elevations are important factors in restricting the present distribution of these forms, but so little is known about the life history, physiology, and ecological requircments of these animals that it is useless to speculate further on these matters.

In several ways the yonahlossce group appears somowhat closer to $\underline{P}$. whrlei than do the members of the glutinosus group. For example, 
some caddoensis and ouachitae possess toes which are slightly webbed, approaching the condition in wehrlei. The presence of red dorsal spots in the young of yonahlossee (and possibly ouachitae) are similar to those in the young of southern wehrlei (but these are also presont in the young of two wembers of the Glutinosus group, jordani and shermani). On the other hand, all three species in the yonahlossee group have an average of more vomerine teeth than both mehrlei and the glutinosus group, and all three resemble the glutinosus group in possessing 17 trunk vertebrae, as opposed to the 18 of vehrlat. It is apparent that no one species in the yonahlossee group is closer to wehrlei than any of the others. Thus, it rould soen that, as a group, their relationship to wehrlef is quite remote.

The knowledge of the three species in this group has recently been surmarized and augmented by two excellent papers by Fope (1950) and Pope and Dope (1951). I.ttle new inforation on variation, ecology, and life history, other than that already discussed, can be offered here.

Grobnan (1944: 278) has discussed the relationship between ouachitae and yonahlossee and suggested the need for further morphological as well as experimental studies to determine whother the two should be considercd separate species, different subspecies, or undifferentiated populations of the sane species. The work of the l'opes has demonstrated that these forms differ in size at maturity, naxinum size, coloration, and in the number of romerine teeth, although there is oone overlap between the two in the last two mentioned characters. Consequently, they are certainly not undifferentiated populations of 
the same species. Whether to consider then different spccies or subspecios is more difficult to determine. The differences between them appear, however, to be as great or greater than those between other distinct species in the genus (o.g. jordani and Elutinosus; cinereus and dorsalis; or dunni and vehiculum). It would seem best to continue to regard them as separate species. Pope and Pope (1951: 14:9) suggest that the relationship between caddoensis and cuachitae might be subspecific, but the differences in vonerine teeth, size, and color pattern would appear to indicate that they, too, have reached the species level of differentiation. The three might appropriately be called a superspecies (Mayr, 1931: 2).

\section{Plethodon yonahlosses Dunn}

Plethodon glutinosus (Green). Brimley (1912: 137-8)

P1ethodon yonahlossee Dunn (1917: 598-603). Dumn (1920: 130-1). Breder and Breder (1923: 15). Dunn (1926: 129-33). Bailey (1937: 2-3). Gray (1939: 106). Bishop (1943: 287-90). Grobman (1944: 287). Wood $(1947: 273-4)$. Hairston and Pope $(1948: 276-7)$. jairston (1949: 53-6). Pope (1950: 79-105). Newman (1954: 13).

Type:- AMrH 4634, collected near the Yonahlossee Road, about li miles fron Linville, Avery County, North Carolina, at an altitude of 4200 feet, on August 16, 1916, by E. R. Dunil and W. S. Hevin.

Diagnosis:- A large species, with paired dorsal red spots in the roung, and a dorsal chestnut-colored strlpe in the adult. Guanophores lacking In the region of the dorsal stripe, but concentrated on the sides to form a white or light gray lateral band. 
Range:- Northeast of the French Broad River in the BIue ibidge Province of North Carolina, Tennessee, and southeastern Virginie (figure 21). Pope (1950: 82) mentioned that this species had nover been found east of the New River in Virginia, but more recently, Newman (1954: 13) reported two specimens from Kibler Park, Patrick County, Virginia. It may eventually be found farther north in the Blue Fldge Province in Virginia (Floyd and Franklin Counties).

Description:- The belly is black with few to many small white spots. The throat is usually light. The dorsal chestnut-colored stripe is made up of both red and black pigment. The red pigment appears to be somemat similar to the red pigment of jordani and shemenis, but the additional presence of black pigment gives the animal its characteristic chestnut-colored dorsum, rather than the bright red of the other forms. The black pigment is concentrated around the mucous glands in the skin. The young possess paired dorsal red spote and these often remain evident after several years of preservation, unlike the chestnut band of the adults. The reason for this appoars to be the absence of melanophores in the red spots of the young, so that when the red pigment dissolves in the preserving fluid, a light melanophore-free "spot" remains. In the aduit, the melanophores occur over the entire back, so when the red pigment disappears, the animal appears black. Occasional specimens have a reduced amount of red pigment on the dorsum in life, and one specimen reported by Pope (1950: 97) lackod the dorsal red pigment completely. The lateral guanophore pigmentation is so concentrated that in most individuals it forms a light gray or white lateral band. 


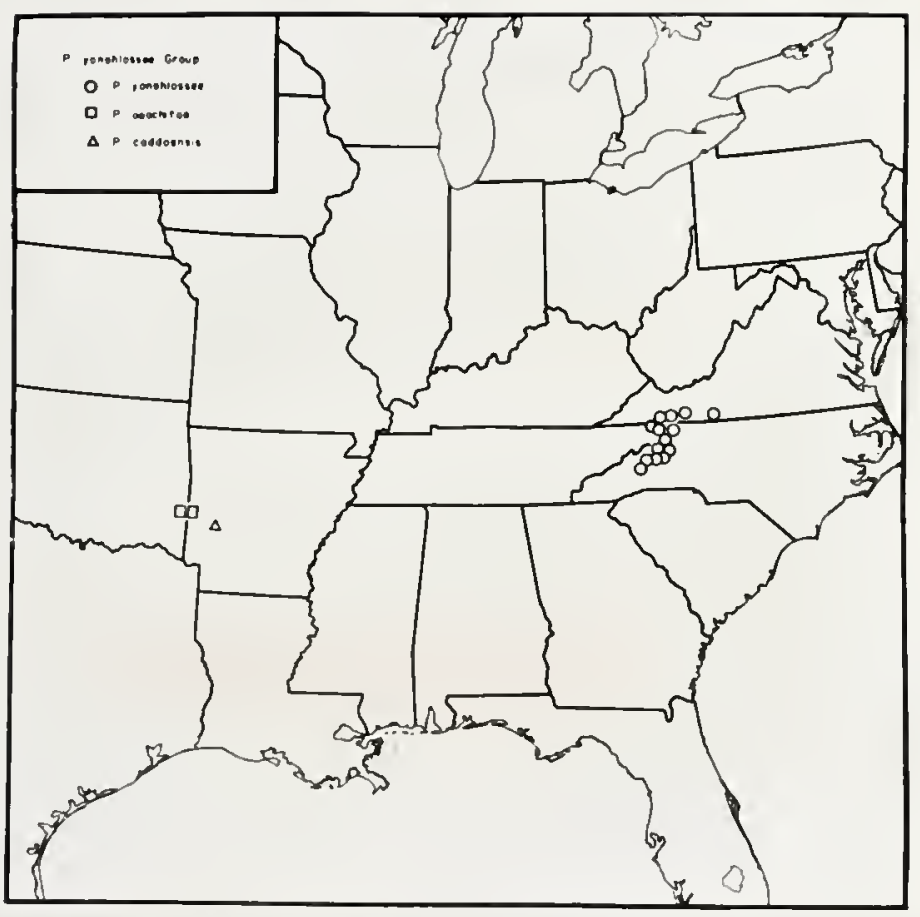

Figure 21. The distribution of the Plethodon yonahlossee Group. 
The costal grooves usual.1y nurber 16, the trunk vertebrae 17. Vomerine teeth range from 5 to 22 in a series, a greater number than in any other Plethodon. The langest specimen examined by Pope (1950) was a female, $85 \mathrm{~mm}$. In snoutrvent length. Sexual maturity is apparently reached between 55 and 65 . In snout-vent length.

Plethodon ouachitae Drmn and Heinze

Plethodon ouachitae Dunin and Keinze (1933: 121-2). Bishop (1943: 26972). Groman (1944: 285). Pope and Pope (1951: 12.9-52).

Type:- USNM 92484, an adult male, collected on the north side of Rich Hountain, Polk County, Arkansas, on Hay 30, 1933, by Albert A. Heinze and Dorothy A. Boyer.

Diagnosis:- A moderata-sized specles with a dorsal chestnut-colored stripe as in yonahlossee, but with numerous white spots and brassy flecks on the back, that are not present in yonahlossee. The lateral band is often yellow in color, whereas in yonahlossee it is usuelly white or very light Eray.

Range:- Known only from Rich wountain in Polk County, Arkansas, and Lerlore County, OkIahona (figure 21). Also reported by Dundes (1947: 118) from MeCurtain County, OkIahasa, but Pope and Pope (1951: 134) present arguments that the specimen on which this record is based is not ouachitae, but an undescribed form.

Description:- The variation in over a hundred specimens of this species has been studied by Pope and Pope (1951). I have examined only three living specimens of this species, so reference is made to their paper 
for the frequency of the occurrence of piementation characters.

The belly is dark. The intensity of melanism on the chin is variable, ranging from very dark in a small percentage of specinens to little evident or lacking in 27\%. 93\% of the Popes' specimens possessed yellow or white spots on tho chin and over half possessed these spots on the belly.

Lateral white or yellow pigment is so abundant on the sides that in $85 \%$ of the specimens it forms a continuous band.

The back has four different types of chromatophores. Black pigment is present on the dorsum and is concentrated around the glands In the skin, as in yonahlossee. Between these glands there is a fairly uniform amount of red pigment. In addition there are two kinds of guanophores scattered over the dorsum. There are small white spots (the "white speckling" of Pope and Pope) and smazler brassy flecks (their "frosting"). The white spotting was lacking in $2 \%$ of their specimens and the brassy flecks were lacking in 19\%. There was considerable variation in the abundance of both types of guanophores. There is also a great deal of variation in the amount of red on the back. In $21 \%$ of their specimens they state that the back was nearly all black.

After preservation, a $26 \mathrm{~mm}$. Juventle exhlbited two rows of faintly pink spots on the back, indicating that this form may have the juvenile red spots present in several other Eastem Iarge Plethodons.

The costal grooves usually number 16, the trunk vertebrae 17. Vomerine teeth range from 4 to 18 in a series. The largest specimen, 
a fenale, is $67 \mathrm{~m}$. in snout-vent length. Sexal maturity is apparently reached between 45 and $55 \mathrm{~mm}$. snout-vent length.

\section{Plethodon caddoensle Pope and Pope}

Plothodon ouachitae Dumn and Heinze. Grobman (1944: 285, part). Plethodon caddoensis Pope and Pope (1951: 148).

Type:- CNHA 61959, a female collected at an altitude of 1200 feet on Polk Creek Mountain, Montgonery County, Arkansas, by Sarah H. Pope, on Nay 9, 1950.

Diagnosis:- A small species with melanophore pigmentation almost entirely absent on the chin and belly anterior to the fore-legs. Dorsal spots are larger and more numerous than in P. glutinosus. It possesses an average of more vomerine teeth for its size range than any other Plethodon. The toes are often slightly webbod at the base.

Range:- Known only from the Caddo lountains of southern Montgomery County, Arkansas (figure 21).

Description:- This species has not been examined in life and little more can be offered than that already discussed. Pope and Pope (1951) give a description of the holotype and two paratypes in life.

The costal grooves usually number 16, the trunk vertebrae 17. Vomerine teeth range from 7 to $l_{4}$ in a series. This is a small species, the largest specimen of 39 examined is $52 \mathrm{~mm}$. In snout-vent length. Sexual maturity is reached at about $40 \mathrm{~mm}$. snout-vent length. Pope and Pope believed that all three of their specimens were immature, although two of these were 45 and $47 \mathrm{~mm}$. In snout-vent Iength. 


\section{$-106-$ \\ Plethodon glutinosus Group}

Plethodon jordani

In 1901, Blatchley described a red-cheeked Plethodon from the Great Smoly lrountains as Plethodon jordani. During the next three decades, three additional related forns were described by Stejneger (1906) and Brimley $(1912,1927)$ as separate species, although each was obFiously closely related to $\mathrm{P}$. jordani and inhabited an adjacent region. Both Dunn (1926: 146; 151) and Grobman (1944: 289) commented on the close relationship of these forms and suggested that intergrades between some of the adjacent forms might eventually be found. Brimley also recognized their close relationship and mentioned that "they hardly seem distinct enough to be full species" (1928: 23). The studies of halrston and Pope (Hairston and Pope, 1948; Pope and Hairston, 1948; Hairstan, 1950) added three new forms to the group and demonstrated that intergradation occurs between several adjacent forns. In 1950, Halrston recognized seven subspecies of $\underline{P}$. jordani, and another supposed member of this group (․ kentucki) was described by liattlenan as a distinct species in 1951. It was later 1ister as a subspecies of Plethodion jordani by Schmidt in 1953, but Clay, Case, and Cumninghan (1955) have shom that the specimens on which it based are actually P. glutinosus.

In spite of the fact that much has been learned about the systematics of this group during recent years, there still remain numerous gaps in the knowledge of the distribution and relationships of many of the forns, some of which have heretofore been recorded only from a single type locality. During the sumer of 1955, I had an op 
portunity to spend several weeks collecting in the scuthern Appalam chians and a special effort was made to obtain salamanders of this group from several critical areas. In addition, a large number of plethodons of this species in the University of Flomida collection, assembled since 1951 by Dr. Arnold B. Grobman, Walter Auffenber, Edrin II. MeConkey, the writer, and others, were available for study. This new material has denonstrated the close relationship of certain members of the jordani group with Plethodon glutinosus, as well as providing information on the relationships among the several subspo cies. In addition, one nem form was discovered. Recent collecting outside the southem section of the Blue Pdge Province, in which these salamanders were formerly believed to be largely restricted, has indicatel that some of the forms may have more extensive distributions (Hoffman and Kloinpeter, 1948; Hof man and Hubricht, 1954). Wth the continued building of roads into previously poorly accessible areas of the southem Appalachians, opportumities for additional profitable studies with this group are increasing.

Careful color notes from life were ade on the specimens I collected during the summer of 1955 and the entire collection ras critically examined, after preservation, in September, 1955.

Each series was studied in order to determine whether it could be assigned to either the light-bellied or the dark-bellied group of subspecies. The importance of the difference in intensity of ventral melanophore pigmentation has been emphasized by Bailey (1937), Grobman (1944), Hairston aid Pope (1948), and Hairston (1950), as an imortant character in the study of raciation in this species. The subspecies 
jordani, melaventris, clensonae, rabunensis, and teyahalee wore ro garded as dark-bellied races, while metcalfy and shemani were docribed as being light-bellied. No one has offered an explanation for the discontinuous distribution of the light-bellied populations. The nem material that has been collected in the last five years indicates, horrever, that several other populations of Plethodon jordani are lightbelliod. These occur in the northern Cowee jountains (a range lying botween the Nantahal. Mountains Inhabited by P. I. shermani and the Balsan Mountains inhabited by P. I. metcalfi); in the Unicoi Mountains (this population will be deseribed as a new subspecies, $\underline{P} \cdot \underline{j}$ unicoi, bolow); and in the Great Smoky fountains.

In order to study the intensity of ventral melanophore pigmentation in an objective manner, the freshly preserved specimens collected during the summer of 1955 were compared with a standard color guide (Villalobos and Villalobos, 1947) and the degree of darkness of the belly recorded. Since lmwature specimens of all the forms have much lighter bellies than adults, only the variation in sexualiy mature individuals studied. Table VII shows the date on this character ob tained from specinens taken in various parts of the range of Plethodon Jordani. It is obvlous that there is considerable variation in the darkness of the bellies of specimens in each population. However, with the exception of ?. j. jordani, the forns considered to be dark-bellied by previous worker, do average darker than those which were considered to be light-bellied. P. 1 . Jordani should actually be considered a light-belliet subspecies, since the average bolly pignentation is well whin the range of the other light-bollied races (shermani and metcalfi). The distinction between light and dark-bellied populations is not $a b-$ 


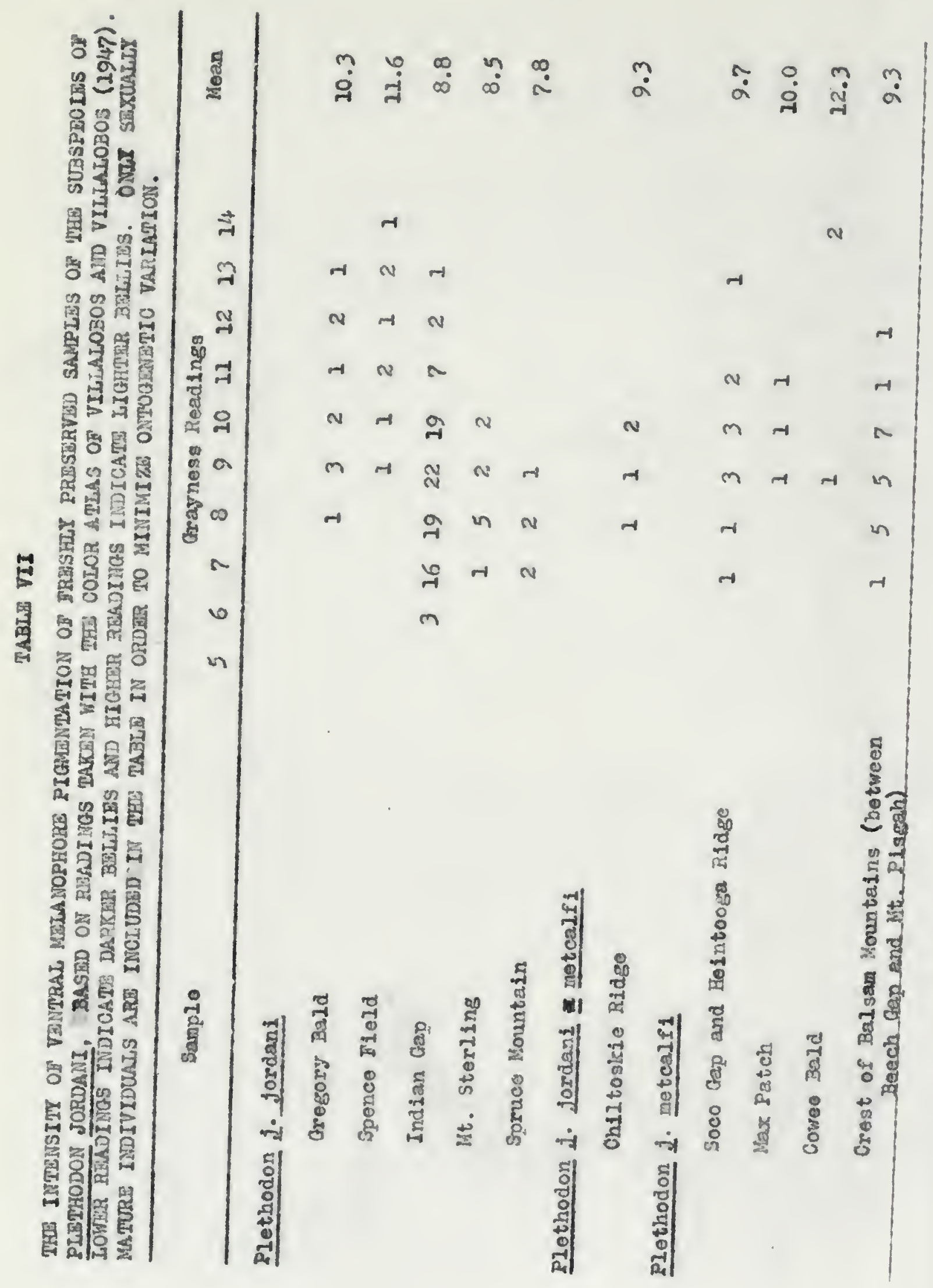




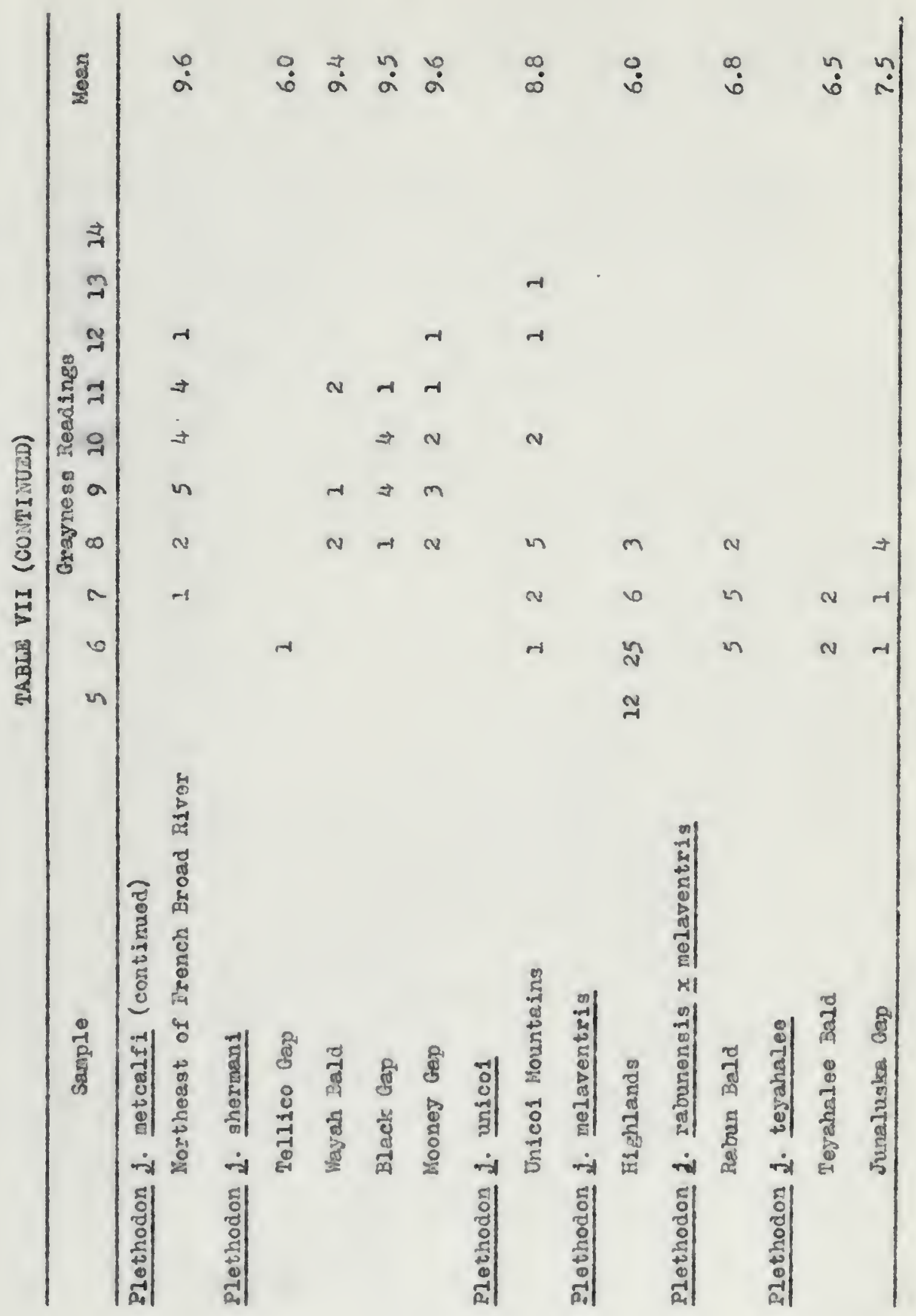


solute, but is only an average difference that can be detected by examining series of freshly preserved specimens. Nine living adult specimens from Grandfather Mountain (metcalf1) are almost as dark as proserved melaventris (range, 5-9; mean, 7.0), and 21 living adult melaventris are slightly darker (range, $2-7$; mean 4.7 ). Again, an average difference exists, but living specimens cannot be compared with preserved specimens, and probably additional fading may be expected after several years of preservation. Different preservatives probably give rise to other variations in amount of fading.

A series of ten living specimens of metcalfi from Grandfather Mountain and ten living melaventris from Highlands were both separated into two groups of five ach and one kas kept in light and the other in dark conditions for eight days. At the end of this period, the four groups did not appear to have changed detectably in the intensity of their melanophore pigmentation. In a similar experiment, Grobman (1950) found that the belly pigmentation of light- and dark-bellied races of Desmognathus fuscus was subject to changedin intensity when exposed to different light conditions.

The distribution of the light- and dark-bellied populations of Plethodon Jordani can now be reexamined in the light of these new data. If populations averaging 7.5 or under are consldered dark-bellied and those over 7.5 light-bellied, it can be seen from figure 22 that the light-bellied populations (jordani, metcalfi, shermani, and unico1), represented by hollow symbols, are not isolated from one another by intervening dark-bellied populations, as was fomerly believed. If populations that average 8.0 and over, or 8.5 and over are considered light-bellied, and the remainder dark-bellied, the results would be 


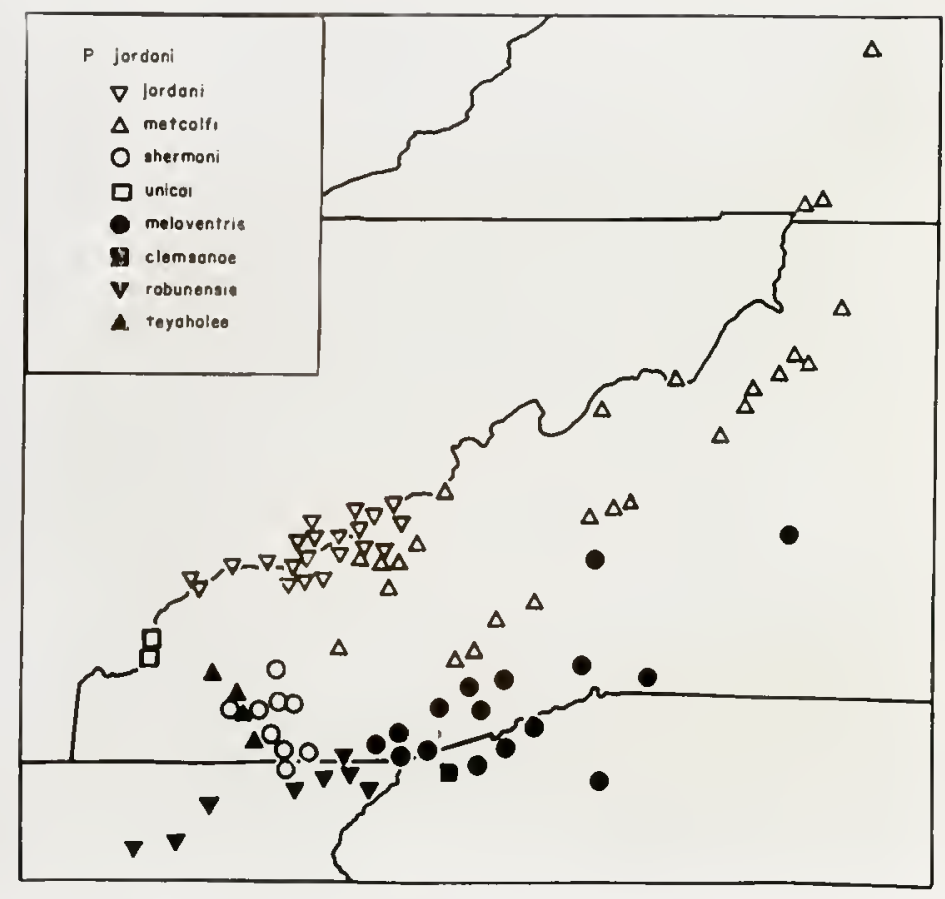

Figure 22. The distribution of the subspecies of Plethocion jordani. Solid symbols represent dark-bellied races and hollow symbols represent light-bellied subspecies. 
similar. If a lighter dividing line were used, then some races here considered light-bellied would include both types. The dark-bellied populations (melaventris, rabunensis, clemsonae, and teyahalee), indicated by solid symbols in figure 22, apparently occur in the southern portion of the range of Plethodion Jordani.

Most previous workers were convinced that the subspecies of Plethodon Jordani were either isolated in the present mountain ranges or in the valleys between then during former periods of different climatic conditions (see liairgton, 1950, for a discussion of this probIem). The prosent distribution of the races of Plethodon jordani does not necessarily support either of these views. P. j. metcalfi, for example, occurs in several different mountain ranges (Black, Balșan, Cowee) that are separated by low uninhabited river valleys. It intergrades with $\underline{P} \cdot \mathbf{j}$. jordani at high altitudes in the northerm Balsam Hountains. On the other hand, it is separated from $\mathrm{P} \cdot \mathrm{j} \cdot \underline{\text { shermani by }}$ the valley of the Little Temessee River. $\underline{P} \cdot \underline{\underline{j}}$. shernani occurs on both sides of the Nantahala Piver, although a few miles rest of the river 1 t is replaced by $\underline{P} \cdot \underline{1}$. teyahalee. $\underline{P} \cdot \underline{1}$. melaventris and $\underline{P} \cdot \underline{j} \cdot$ rabunensis intergrade in the vicinity of Rabun Bald, the highest elevation between the ranges of the two races. It is apparent that some races are separated by river valleys, while others are separated by mountain ranges. Intergradation usually occurs in the mountain ranges where two forms come together, but cannot occur in some of the deep valleys that are presently ecologically unsuitable to members of this species. River vall fys and high mountain ranges may thus both servo as barriers between pairs of different subspecies, and both appear to bo factors important in the present distribution of the subspecies of 
P. jordani.

The first differentiation that occured in $\underline{P}$. jordani was probably a separation of the proto-jordani stock into a northern lightbellied form and a southern dark-bollied form. It is useless, at this time, to speculate when or how this occurred, since we have no idea of the geologic age of the spectes concerned. Later, each of these forns developed four restricted groups that can be recognized today as separate subspecies. Dhring the "leistocene, climatic changes were frequent, and it is quite possible that at different times both river valleys and mountain ranges acted altemately as routes of dispersal and barriers to migration.

The differences between the two major groups of races are not limited to belly pigmentation alone. The northem races are smaller and show a more marked sexual dimorphism in the swolling of the snout in males. Dorsal guanophores are absent in the northem light-bellied foms, although present in several populations of the southem group (clemsonae and teyahalee). Lateral guanophores are present in both groups, but are most abundant in the southern populations, especially rabunensis. Red lipophores appear in shermani and jordani and occastonally in other populations, especially those adjacent to sherrani. The northem races are restricted to higher altitudes, whereas the southern dark-bellied races occur at low altitudes (under 3500 feet) as well. The southem forms are morphologically much more similar to glutinosus, and the two species often coexdst in the same habitat, while the northem, light-bellied forms are usually altitudinally separated from P. glutinosus (llairston, 1951). 
The subspecies jordani and shermani are obviously closely related. Both forns have young that have similar red dorsal gpots (Bailey, 1937: 5-6; Vood, 1947a, 1947b). Both have fairly light bellies and both possess rei pigment as adults. lisirston (1950:270) suggests that intergradation may have taken place between the two dusing the Pleistocene when the Little iennessee Hiver Valley might have been inhabited by the two. The Cheoah Kountains, which rise to over 5000 feet in alevation, lie directly between the Smokies and the Nantahalas and an intermediate population may be present there at this time. This area should certainly bo searched for it probably supports a member of the jordani groux. One might expect shermani, teyahalee, jordani, intermediates between any of these, or perhaps, a now form. Hairston (1950) reported intergrades betwoen jordant and metcalfi, metcalfi and melaventris, and rabunensis and shemant. He is probably correct in suggesting that jordani and shermani are very closely related, rather than being circuitously connected through the subspecies metcalfi, melaventris, and rabunensis.

Hairston (1950) reports intergrades between jordani and metcalfi from fratt Plige, a ridge that runs south from the vicinity of ilt. Guyot in the main Smoky Mountain chain. I have examined some of his specinens (GSMNP Pm 20-29) and agree with the interpretation that they are intermediate between the two gorms. A series of 10 specimens from Spruce liountain (GSLNP PJ 96; UF 8150), 7 miles east of Fratt Ridge in the direction of the range of metcalfi, are typical jordani (except for one specimen that has a reduction of red plgrent on one cheek). Four miles to the south of Spruce Hountasin, at lleintooga Ridge, 15 specimens (UF 8121, 8250) a.1 complotely lack red plg- 
ment on the cheeks. At Chiltoske Rldge, about half way between these tro localities, six specimens (UF 8147) are internediate between fordani and metcalfi. Of these, one specimen has no red on the cheeks, another has nomal jordani red cheeks, and the remaining four all have a very reduced amount of red on the cheeks. The zone of intergradation betreen the two forms on Balsam Mountain therefore appears to be very narrow (i.e. less than four miles). King (1939: 553) reports taking the two forms less than a mile apart without any evidence of intergradation. He does not give the exact location of his collections, but 15 specimens from lyatt Pidge in the GSINP collection (Pn 1-13, 3500'; Pu L 14-15, 4080') all appear to lack any trace of red on the cheeks. Two specimens (GSIRP PJ 81-82) taken at 4,500 feet on Hyatt Ridge, are fairly typical jordani. Unfortunately, no further locality data are available for any of these specimens, but they indicate that both falrly typical fordani and metcalf1, as well as intergrades between the two (see above), occur on flyatt Ridge, the same situation that occurs on Balsam wountrin, the next ridge to the east.

King (1939: 551) reports that only two of several hundred specimens of jordani from the Smokies that ho exanined lacked red cheeks. There is, of course, considerable variation in the amount of red that occurs on the cheoks of jordani at the type locality in the center of its range where the incidence of red plpmentation reaches its greatest development. Some specimens have red extending across the gular region, shoulders, and even onto the fore limbs. Others have the red restricted to a part of the cheek only (usually the upper half). In examining the specimens of jordant in the GSIRP collection, I found only two that lacket any trace of red on the cheoks. One, Py 22, is from Ut. Sterling 
at the extrerse ast end of the Park, and the other, Fj 45 , is one of two specimens wth the siine number. Thero is no specimen labelied Py 54, so apparently an error has been made in tagging the specimens. Since Py 45 and $\mathrm{PJ}$ 5h are from different localities (lughes kidge, and Iong lunery Ridge, respectively) some 33 miles apart, it seems best to disregard this record.

Tro series collected by the writer chring the summer of 1955 , at Gregory Bald (UF 8125) and at it. Sterling (UF 8141), at opposite ends of the Park, both show a great reduction in the anount of red on the cheeks. None of the 33 spocimens from Gregory bald comgletely lack red check pigment, but $18(67 \%)$ have less red on the cheeks than 138 of 141 topotypes examined from Indian Cap (UF 8094, 8141, 8254). The sories from Greery lald nay be tending slightly toward the now form, unicoi, in that several specinens havo small winite spots on the sides of the head and boty. Of $u_{1}$ speclens from st. Sterling, two entirely lack red cheek pigment, six have it gratily reduced, and six fall withIn the usual range of topotypes of jerdani. The specinens fror ut. Steriing way be approaching metcalfi, wilch is known from two locallties an the Cataloochee Divide (GSMiv Fin 16, Sugar Tree Iick; and UF 8144, Cove Creek Gap). Four specinens from kax Patch Hountain (UT 8135), on the east side of the Pigeon River, are typical metcaifi.

Specirans in the GSINP collection from many localltles in the central portion of the Smokles are all similar to topotypical jordani. Large serles from single localities are not avallable, except from the type locality, so it is inpossible to analyze populations from different areas in order to detemine, to any further extent, whether or not 
any trends in the reduction of red pigment on the cheeks and intensity of ventral melanophore development are present.

P. 1. metcalfi has the most entensive rango of anj of the races of $\underline{p}$. Jordani. It occurs from the Cowee and Ralsam Lountains in south westem North Carolina to southwestern Virginia. The northerm-most record for metcalfi in Virginia is Burkes Garden (Hoffman and Kleimpeter, 1948), a locality in the Valley and Ridge Physiographic Province. This race seems to be fairly unifom throughout its range. The fact that an isolated population of metcalfi occurs on Cowoo Bald in the Cowree Lountains seams to indicnte that there vas a former connection across the present Iow Tuckascigee River valley with metcalfi populations in the Belsam lountains. The Cowee irountains range to the southeast into nelaventris territory and thus do not connect directly with any other mountain range known to be inhabited by metcalfi.

The young of metcalfi have not been described. A special effort was made to obtain such specimens in order to ascertain whother or not they possessed the red dorsal spots of juvenilo shermani and jordani. Only three young of the year were found, all from the vicinity of Lit. Pisgah, in southern Haywood County, North Carolina. None had any red pigment and two, both $19 \mathrm{~mm}$. in snout-vent length showed no trace of guanophores either. The other specinen, $20 \mathrm{~mm}$. In snout-vent length, had numerous guanophores scattered over tho back and sides, unlike any adult metcalfi exantned.

Hairston (1950) presents evidence for intergradation batween metcalf1 and melaventrls in the southom Balsam hountiins. He compared specimens from both the northern and southern slopes of the Balsans in 
the vicinfty of Beech Cap, and found an apparent increase in darkess of the belly from north to south. Jost lightmbellied populations include spectmens that are as dark as some melaventria or rabunensis (see table VII), but samples fron the top of the Balsam yountains; near Beech Gap (UF 8109), near Wagon Road Gap (UF 8108), and Kt. Pisgah (UF 8145) average only slightly darker than other samples of metcalfi. Intergradation between these two forms probably takes place to the south or southwest of the top of the Balsan Hountains in this area, not on the crest of the mountains. I have not examined froshly preserved or living material from any localities between Beech Gap and Highlands. Until such material is avallable from these areas, I would hesitate to assign subspecific identifications to the populations that excist in this area, as well as to those reported from Durke, Henderson, and Polk Counties, North Carolina, and from Greenville and Plckens Counties, South Carolina, by Grobman (1944), Hoffman and Hubricht (1954) and Schwartz (1953: 156; 1954), although these workers assigned specimens from these counties to the southern dark-bellied form (melaventris). These localities are tentatively indicated on the distribution map of these forms as melaventris (figure 22). The great difficulty in distinguishing preserved P. glutinosue and the southem darikbellied races of P. jordani casts some doubt on the correct identification of some of the records of melaventris cited in the literature.

At high elevations in the Unicoi Hountains, at altitudes above Lo00 feet, in the vicinity of Haw Inob and Johns Knob, a light-bellied population of P. Jordani was discovered by Dr. Amold B. Grobman in 1950. In the same year, Hairston described $\underline{P} \cdot \dot{1} \cdot$ teyahalee, based on seven specimens from Teyahalee Jald in the nearby Snowbird Mountalns. 
The comparison of living topotypes of teyahalee with the form from the Unicoi lountains reveals that the latter population is not teyahalee, but an undescribed form. It is distinguished from teyahalee by its lighter belly, the absence of small red spots on the legs and the usual absence of tiny white spots on the back. Its light belly also distinguishes it fror rabunonsis, melaventris, and clemsonas. The absence of red pigment distinguishes it from jordani and shermani, and the presence of lateral white or yellow spots distinguishes it from metcalfi. As noted above, specimens of jordani from Gregory Bald, in the extreme vest end of the Great Smoky hountains, show some tendency toward unicoi characters, and may represent intermediates between the two forms.

P. 1. shermani, the rech-legged forn from the liantahala Wountains, occupies an area extending from Tellico üap, in the northern portion of these mountains, south to the vicinity of the Georgia state Iine. Bailey (1937:5) records this race from the iusquitee lountains, Indicating a geographic overlap of shermani and teyaharce (see below).

Hairston (1950) reports several series of dark-bellied shermani from the periphery of its range. One of these localities is Tellico Gap, in the northern llantahala Lountains. Two fresh specimens (one of then imiature) from this locality (UF 8178) also have very dark bellies. As postulated by llairston, since the dark-bellied forms occur in adjacent areas, at least to the scuth (rabunensis), southeast (melam ventris), and west (tevahrlee), the dark-bellied populations on the periphery of the range of shermani may represent intergradation between ehcrmani and these dark-bellied races of $\underline{P}$. jordant. 
near Aquone, west of the Nantahala lountain range, that ho rçarded as intercrades botween Plethodon shemeni and Plethodon Elutinosus. A.t that time, none of the dari-bellied races (cxcept clemsonae) had been described. I. have examined Elshop's specimens (CMHM 93241-2; 93250-7) and 212 but one (CNHI 9324I) heve a great rechucicn in the arnount of red plgment on the leg:, as in teyahalee. Their bellies vary from quite dark to fairly light and seem to brioge the gap between the light bellied sherrani and the cark-bellied teyahalee. It would seen best to regard them as intergrades between terahalee end shormani, but closer to teyahalee. Bailey (1937: 5) reports a series of five specimens taken about half way between Nantahala and Aquone, in which two resembled glutinosus, (presumably these had dorsal mite spote), two had reduced red on the legs, and the other lacked both white and red pigment. These probably also represent intermediatos between shermani and teyahalee. Specimens of $P$. 1. teyahalee from the west side of the Nantahala river in this area (near junaluska Gap, UW 8029; 8091; 8174; 8176 ) al1 possess small red spots on the legs, as well as the small dorsal white, characteristic of teyahalee (sec below).

Hairgton and Pope $(1948)$ belleved that specimens from Gap, in the southem part of the range of sliernanj., reprssent intergrades between shermani and rabmensis. Six of a series of thirween fresh specimens (I5 8179; 8184) from near Hooney Gap possess a narked reduction of red on the legs, but they do not tend toward rabunensis in other charactors. Their bellies are light and they appear to be well within the range of eleven Wayah Dald 3hemani (UF 8101; 8106; B107) in asount of lateral yellow of wite guanophore pignentation. Whach more fleld work is needed to definttely establish intergradation between these two very 
distinct subspecies. Hartof and Humphries (1955: 246) report shemani from extrense northwestem Rabun County, Georgla. They state tirat their specimens possess black bellies. These may be intergrades ietreen rabunensis and sherrani.

A series of eleven specimens (UF B393) of typical shermani from Black Gap on the Wacon-Clay County line and the record of Bailey (1937) for the Tusquitee ifountains, establishes the presence of shernani on the west side of the Ilantahala Plvor. Three specimens from Glade Gap (UN 8032), about three miles west of Black Gap, have very reduced red pigmentation on the legs, and the single adult has a dark belly. A specimen (UF 8410) from near Tuni Gap, to the northwest of Glade Gap, on the llacon-Clay County line, scens to be typical teyahalee, yet Bailey (1937) reports shermani from Jeatheman and Tusquitee Elalds, two miles further west. These records suggest slight overlep in the ranges of these two forms and this area should be more carefully studied in the future.

Wore than half of a series of 22 specimens (UF 8301) from Jarrett knob, on the east side of the Nantahala River, south of Aquone, have red on the legs either very reduced or absent. The bolly color is variable, lut would appear to be intermediate betwoen tho light- and dark-bellied forms.

P. 2. teyahalee was previously knom only from the typo locality, Teyahalee Bald, in the Snowbird lountains. A comparison of living topotypes (UF 8166; 8168) from over 4000 feet elevation on Teyam hal ee Bald with specimens from Tuni Gap and Junaluska Gap, mentioned above, indicates that they are the same form. The original diagnosis 
of terahalee does not distinguish it from rabunemsis, and it would have to be synonymized with rabunensis were it not for the fact that most specimens may be distinguished from rabunensis by the possescton of tiny (less than $0.3 \mathrm{~mm}$. In diameter) white dorsal spots. These spots are similar to those of Plethodon glutinosus from westerm North CaroIna, but are wuch smaller. Specimens of teyrahaloe usulily possess small red spots on thelr legs, a character laching in most rabunensis snd giutinosus.

There are no records of teyahalee from the Snowbird lowntains west of Teyahalce Bald. This mountatn range axtends to the west and joins the Unicoi renge, with altitudes high enough to support a nember of this group for most of the distance. Intergrades betwoen unicoi and teyahalee may eventurly we found somewhere in this mountain range.

$$
\text { P. jo rabunensis (type locality, Rabun Bald, Georgia) is }
$$
diagnosed as a dark-bellied form possessing lateral white spots. Specimens from areas to the south and east of Habum Bald (southern Rabun, Inion, and Toms Counties, Georgia) have a much greater development of the lateral white spotting. It is apparent that Pabun Bald specinens are intermediate in this character between southem Rabun, Union, and Towns County specimens and melaventris. Thus the type locality of rabunensis is located in a zone of intergradation. However, since the type specimen possesses lateral white spots, characteristic of the Georgia race, the nare rabunensis can still be applied to this subspecies.

Specimens of rabunensis with abundant white or yellow spotting are avallable from: Persimnon (UF 8408), and 12 miles east of 
Clayton (UF 8LO7), Rabun Gounty; Jack Gap, Union-Towns Gourty Iine (Chis, uncatalogued); and 4 miles east of Margaret, Union County (Us, uncatalojued). These specirens are very similar in appearance to $\underline{\underline{P}}$. glutinosus, and the relationship between the two may actualiy be very close. The lack of a good systematic character to distinguish between rabunensis (and teyahalee) and glutinosus makes the identification of Iiving spocimens difficult and preserved specinens almost impossible. The leck of dorsal spotting on most rabunensis usually serves to distinguish between the two in life, although occasional specinens of glutinosus from areas outside the southem Appalachians appear identical to 1t. (In certain localities in the Castal Plain, P. glutinosus may often lack white pigment completely and cannot be distinguishod from melaventris.) Specimens of $\underline{P}$. glutinosus from near the range of rabunensis that I have examined in Iifo, from Iullulah Gorge, Rabun County, and Potato Patch Mountain, Murray-Gilmer County line, possess small brassy dorsal spots similar to Florida glutinosus. However, all the P. glutinosus from southwestem North Carolina that I have examined possess white dorsal spots. I have collected this mite-spotted form of glutinosus living in the same habitat with members of the jordani group at Soco Gap (Swain-llaywood County Iine), Covo Creek Gap (Haywood County), Wax Patch Mountrin (Haynood-liadison County Iine), Cowee Bald (Nacon-Jackson County line), Highlands (lacon County) in North Carolina, and at Jocassee (Oconce County), South Carolina. At the first four mentioned localities it was associated with metcalfi, at Highlands it was associated with melaventris, and at Jocassce with clcmsonae. One specimen collected at Rabun Bald along with a series of topotypio rabunansis, also appears to represent this form of glutinosus. It has white 
doreal and gulsr spots, unlike any other specimens in series of rabunensis, but is otherwise indistinguishable from them.

Very likely the series of 34 specimens reported by Bailey (1937: 3) from Blood Mcuntain, Union County, Georgia (Unaz 76334-66), are rabunensis, since only two possessed an appreciable anount of dorsal whtte pigront, their throats are lightor than most glutinosus, and the lateral white pigment is concentrated into a band. This description almost certainly assign this series to rabunensis, al though both Bailey and Hariston and Pope (I9L8: 275) identified the specimens as P. glutinosus.

P. I. melaventris, an unspotted dark-bellied form, occurs comonly in the area around Highlands, Hacon County, Nortks Carolina. As pointed out by Howell and Hawkdns (1954), a small percentage (15\%) of tepotypical melaventrie possess lateral white spotting as in rabunensis. Both tho extent and frequency of occurrence of this character in the Highlands population are not high enough to negato the usefulness of this character in diagnosing the two forms. Unspotted blackbellied specimens, probably referable to this race havo bean reported from several localities to the east of Highlands, but the range of this foma, both geographic and altitudinal, as mell as its apparent sympatric relationship with glutinosus are ruch in need of irvestigation. Two living spocimens of melaventris from the vicinity of lifilands bad dorsal brassy mecks as in clemsona in $11 \mathrm{fo}$, indicating a Low fro quency of oscurrence of this character in the Highiands population.

1. 1. cleasonae was described by Brinley tn 1927 on the basis of fts distinct dorsal coloration (which usualiy disappears in pro- 
servatives), but wes not egain generally regarded as valid until Blshop (1941) obtained additional living specimens from the type locality. This is a low altitude form, occurring in the vicinity of Jocassee, Oconee County, South Carolina. It apparently is very closely related to rabunensis and melaventris, and differs from Rabun Bald specimens only in the possession of small brassy guanophores that are scattered over the entire dorsum. No larger white spots are present on back as in glutinosus. Freeerved specimens are usually not distinguishable from the other dark-bellied races with lateral white spots.

An important problem which remains to be studied is the extent of intergradation between the light- and dark-bellied races of $\underline{P}$. jordani. Hairston (1950) belleved he had intergrades between melaventris and metcalfi from the top of the Balsam Mountains near Beech Gap, but it has been shown above that this population is very close to motcalfi. There is much evldence for intergrsdation betwoen shermani and teyahalee, and shermani may also intorgrade with rabunensis. The greatest difficulty in studying this problem is that after years of preservation, changes take place in the intensity of ventral melanophore pigmentation. Moreover, individual variation is considerable and fairsized sarples should be analyzed. Hence one or two specimens may not be of much use in determining the nature of the population occurring at a particular locality. Except for jordani and shermant, which have melanophore gaps in places where tho red pigment is located in life, most faded preserved specimans must be identified almost entirely on the basis of locality. This adds to the difficulties for it means that fresh specimens from new localities are of limited value unless they can be compared with othor appropriate living specimens. The 
fact that $\underline{P}$. glutinosus is often almost indistinguishable from some of the dark-bellied forns (especially rabunensis and teyahalee) further conpounds the difficulties in conducting systematic studies in the group. P. glutinosus is easily distinguished from the northem light-bellied races of $\underline{P}$. jordani, but appears to be more similar morphologicalls to the southern dark-bellied races than the two

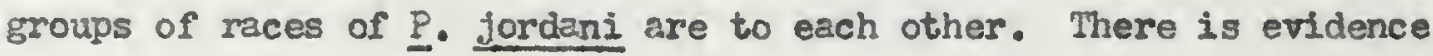
of intergradation between the dark- and lightmbollied races of $P$. jordani and they replace each other geographically, indicating a subspecific relationship. P. Rutinosus, on the other hand, is knom to occur sympatrically with several of the races of jordani without any evidence of interbreeding. According to King (1939: 551), P. glutinosus and $\mathrm{P} \cdot 1$. jordani occur together on Gregory Bald, and metcalfi, clemsonae, and rabunensis have been collected in the same locallty as glutinosus by the writer (see above). llairston (1951) also reports slight altitudinal overlap between glutinosus and shermani. On the basis of his field experience with unico1, Dr. Grobman (personal cormunication) belleves that this form is altitudinally separated from glutinosus on the north slope of the unicoi Mountains in the vicinity of Stratton Gap. As yet, there are no data on this subject for teyahalee. In general, the northem light-bellied races are al.titudinally separated from P. glutinosus (Hairston, 1951) and the localities in which they occur together may happen to be in the narrow zone of overlap between the two specles. However, I feel that extrene caution should be exercised in interpreting the type of negative data presented by Hairston. In experience, a locality that has been intensively collected has often yielded a species of Plethodon that was previously 
believed to be absent. P. Clutinosus 1 often mcch less common than P. jordani where the tro occur together, and can enslly be overlooked, even though a thorough search is made. It seems to me very unlikely that there 1.8 competition between the two for space, food, or some other environmental factor. It seems much more likely that there are other limiting environmental conditions that restrict the altiludinal distribution of the tro species.

It is certainly not irapoestble that $\underline{P}$. glutinosus may be found to bo subspecifically related to one of the southern dark-bellied subspecies of $\underline{P}$. jordani. Two of four specimens identified as glutinosus, from a locality near Highlands, Lacon County, Horth Carolina (UF B271), possessed in lile a slight arount of red pigment on the legs. They were not collected within the range of any race of jordani that possesses red pigment, so they hardly could be considered hybrids or intergrades. Yet the presence of small red spots (similar to those found on teyahaloe) on the legs of glutinosus in the southern Appalachians may be considered further evidence for the close relationship botween $\underline{P}$. glutinosus and the dark-bellied races of $\underline{P}$. jordant. Possibly introgressive hybridization has occurred, or perhaps, teyahalee may eventually be shown to intergrade with both shermani and glutinosus. As yet, no one has made a careful transact from the higher altitudes in the Snowbird Hountains in which teyahalee occurs, down into lower glutinosus territory. A transect of the type done by Hairston (1951) on several other races of fordani would be most valuable. At present, since there is no good evidence of intergradation between the two, $\underline{P}$. Glutinosus and $\underline{P}$. Jordani are still considered distinct species. It is possible that the close morphological similarity betreen $\underline{P}$. Elutinosus 
and southern $P$. jordani is the result of paraliel evolution rather than close relationship, as suggested by lairston and Popo (1948: 276). Grobnan (1944) even places the two species in separate groups within the section of the genus containing the Eastern Large Plethodons, but this interpretation is not followed here.

Plethodon kentucki, describer by lifttleman (1951: 105) as a member of the jordant group from southwestern Kentucky, has been shown by Clay, Case, and Cunninghem (1955) to be based on specimens of $\underline{P}$. glutinosus. I have examined the type series and agree with their interpretation. Many of these specimens still possess traces of the large dorsal, lateral, and gular spots characteristic of glutinosus. Host of the type scries no longer is tagged so it is impossible to determine whtch spocimens were designated as types by lititieman. CSNH $1521 \mathrm{~A}$ was designated as the holotype of $\mathrm{P}$. kentucki, CSNH $1521 \mathrm{~B}$ the a.llotype, and 2521Cod as paratypes. There are now only three specimens in a series of 16 (Mittleman designatcd only 10 as types) that are tagged ("H;" "I," and "J") and there is no specimen of the sex and measurements given for the holotype. It is therefore impossible to deternine which of these specimens ifittleman designated as the holo type. This may become an important problem in allocating the name In futuro systematic work on raciation in P. glutinosus, but, for the present, it does not have to be considered further.

Plethodion jordani jordani Blatchley

Plethodon jordani Blatchley (1901: 762). Dunn (1920: 131). Dunn (1926: 45-6). Brimley (1927: 10). Bishop (1928: 159). Pope (1928: 2-3). 
Veller (1931: 29). Bailey (1937: 6). King (1939: 551-3). Bishop (1943: 261-4). Grobman (191:4: 294). Wood (1947a: 185-8). Eiairston and Pope (1948: 266-78). Deevey (1949: 1367-9) Flethodon jordan1 jordani Blatchley. Hairston (1950: 271). Hairston (1951: $266-74)$.

Type:- Dunn (1926: 145) states that the type specirien vas originally in the collection of $W$. S. Blatchley, but that it has been destroyed. It was collected at it. Collins or Indian Pass, Sevier County, Tennessee, by I. B. Daniels.

Diagnosis:- A lightmbellied subspecies of Plethodon jordani posgessing red checks in the aduit and red dorsal spots in the young. Dorsal and lateral white spots are usually absent, except in juveniles.

Range:- The Grent Smoky Mountains of North Carolina and Tennessee (figure 22). The eastern-most records of this race are mite lick Wountain (nm lit. Camnerer) near the town of ut. Sterling, Hayrood County, North Carolina (Dunn, 1926: 146) and on the east slope of at. Sterling (UF $814: 1$ ). There are specimens in the GSinNP collection represcnting many localities along the crest of the Smoky wountaing (North Carclina-Tennesseo state line) from Nit. Cammerer to Gregory Bald, at the west end of the Great Smoky ilountains National Park. This fora apparently occurs at higher elevations throughout the Park, except in the southeast comer where it is replaced by metcalfi. Intergrades between the two forms are known from Hyatt Ridge (Halrston, 1950: 263) and Chiltoskie :idge. The lowest altitude fron which this race has been reportod is 2500 feet on the slopes of ut. LeConte, Sevier County, Ten- 
nessee (Bishop, 1943: 261).

Description:- This form is characterized by its bright red cheoks. The dorsal and lateral surfaces of the animal are black and the underside is grayish, varying froin fairly light in the young to sonewhat darker in the adurts. The young possess dorsal red spots which are usually arranged in two rows, one on either side of the midline of the anterior half of the back. These are present on most individuals under 30 m. in snout-vent length, but traces of the red dorsal pigmentation may occasionaliy occur on specimens up to $50 \mathrm{~mm}$. in snout-vent length. Wost young indiviouals also have red cheeks. The red pigment of the dorsal spots of the young appears to be the same as the red cheek pigment in adults. Both occur in gaps in the melanophore background. There is considerable variation in the amount of red pigment on specinens from the centrel portion of the Smokies, where large series are available. Some have the red restricted to the upper half of the cheeks, most have the red confined to the sides of the head, but in a few, the red pigraent extends ventrally onto the chin, posteriorly on the shoulders, and 10\% of the specimens from Indian Gap also have small red spots on the front legs. Wost young specimens have sinil brassy flecks on their eyelids, but these diseppear in older indivicuals. The young often possess small lateral spots on the anterior sides, but these aiso seen to disappear with age, so that most advits lack guanophore pigmentation, except in the iris of the eye. More than half the adults exanined possessed brassy iridic guanophores.

The costal grooves usually number 16, the trunk vertebrae 17. Vomerine teeth range from 4 to 12 in each serics, increasing in number 
with larger size (see figure 16). This form is moderate in size, adults rarely attaining a length over $70 \mathrm{~mm}$. In snout-vent length. Sexual maturity is reached between 1.5 and $55 \mathrm{~mm}$, in snout-vent Iangth.

\section{Plethodon jordani metcalf1 Brimley}

Ambystoma jeffersonianum (Green). Fhoads (1895: 402). Brimley (1912: 136).

Plethodon metcalfi Brimley (1912: 138-9). Dunn (1917: 604-6). Fowler and Dunn (1917: 23). Dunn (1920: 131-2). Breder and Breder (1923: 14-5). Iishop (1924: 96). Fope (1924:2). Brimley (1926: 79-80). Dum (1926: 148-51). Moble (1927: 4). Bishop (1928: 160). Viarker (1934: 190). Bailey (1937:6-8). Rankin (1937: 176, 180). Green (1939: 49). King (1939: 553-4). Brimley (19L0:6-7). Bishop (2943: 264-6). Green and Richnond (1944: 256). Grobman (1944: 289-92). Snyder (1946: 174). liajrston and Pope (1948: 266-78). Hoffman and Kloinpeter (1948a: 107). lloffman and Kloinpeter (1948b: 605). Deevey (1949: 1367-9). Hairston (1949: 53-5). Bogert (195?: 16-30).

Plothodon metcalfi metcalfi Brimley. Mittlenan (1948: 416-8). Plothodon jordani mstcalfi Brinley. Hairston (1950: 271). Hairston (1951: 266-74).

Type:- USNi 49682, collected near Sunburst, Haymood County, North Carolina, at an altitude of about $3500-4000$ feet, in late Nay, 1912, by Franklin Sherman and C. S. Brimley.

Diagnosis:- A light-bellied subspecies of Plethodon jordani lacking guanophores and lipophores. 
Range:- From Cowee Bald, Jackson-Macon County line, Hyatt and HeIntooga Ridges, Swain County, and Cataloochee Divide, Inswood County, North Carolina, southeast in the Balsan Mountains to sit. Pisgah, thence northeast in the Blue Ridge Mountains of western North Carolina and adjacent Tennessee to Thite Top Mountain and $\mu_{t}$. Rogers in southwestern VIrginia (figure 22). Also recorded fron Burke's Garden, Tazeivell County, Virginia, by Hoffman and kleinpeter (1948b: 605 ).

Description:- P. j. metcalri is the only light-bellied subspecies that lacks both guanophores and lipophores in the adult. This race has the most reduced ventral melanophore pigmentation of any subspecies of $\underline{P}$. jordani. The sides and back often have a reduction of black pigment ro sulting in a lighter over-all appearance than any of the other subspecies. One small juvenilo from near kit. Pisgah (UF 8108) possessed small dorsal guanophore flecks in life. Very large specimens occasionaily possess a small amount of white pigment scattered through melano phore gaps on the sides and/or belly, but these guanophores are never concentrated into groups to form white spots as occur regularly in teyahalee, rabunensis, and unicoi. Cuanophores are usually absent from the iris.

The costal grooves usually number 16, the trunk vertebrae 17. Vomerine teeth range from 4 to Ih in each series, similar to $\underline{F} \cdot 1$. jordani. This is the smallest race, the largest specimen examined is $66 \mathrm{~mm}$. In snout-rent length, but few adults attain a length over 60 ma. Sexual maturity is reached between 40 and $45 \mathrm{~mm}$. snout-vent length. 


\section{Plethodon jordani shomani Stejneger}

Plethodon shemani Stejneger (1906: 559-62). Brimlsy (1912: 138).

Dunn (1920: 131.). Dunn (1926: 146-8). Btshop (1928: 160-1).

Pope (1928: 4-5). Bailey (1937: 4-5). Grobman (194h: 294-6).

Plethodon glutinosus shemani Stejneger. Bishop (1941: 18-9). Bishop

(1943: 253-6). Wood (19470: 188). Wood (1947c: 273-4).

Plethodon shermani shermani Stejneger. Popo and Hairston (1948: 106-7).

Hairston and Pope (19L8: 27L-5). Deevey (1949: 1367-9).

Plethodon jordani shermani Stojneger. halrston (1950: 271). Hairston (1951: 266-74). Martor and kumphries (1955: 246).

Type:- USlNA 36214, collected near Wayah Gap (on the Franklin side of the Gap), Nacon County, North Garolina, on August 24, 1904, by Franklin Sherman. See Brinley (1912: 138) for correction of originally designated type locality.

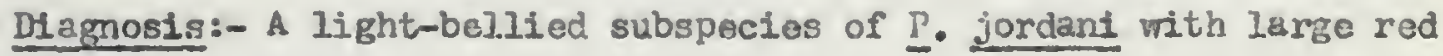
spots on the legs.

Range:- From northwestern Rabun County, Ceorgia, north in tho Nantahala Wountains of Nacon County, North Carolina to Tellico Gap; west to Tusquitee and Weatherman Balds, Choroleo County, and Black Gap, Clay County, North Carolina (figure 22).

Description:- The brllliant red logs of typical specimens of this race make it one of the most strikingly beautiful North American salamanders. The dorsum is black and the underside light in the young, beconing graylsh in the adult. There are usually a fer snall lateral yollow or wite guanophore spots, most numerous just behind the front limbs. The 
young possess ciorsai rad spots similar to those of $\mathbf{F}$. j. jordani young. The red on the legs of the adults is usually most abundant on the proximal half of the linbs. In specimens with the red on the legs reduced, it is generally reduced on the hind lirabs to a grcater extent thar on the front legs. Populations on the periphery of the range often have dark bellies and reduced red on the legs.

The costal grooves usually number 16, the trunk vertebrae 17 . Vomerine teeth vary from 3 to 13 in a series and the ontogenetic increase in number j.s very sinilar to jordani. A moderate slaed form, with dimensions similar to $\underline{\text { P. }}$ 1. jordani.

Plethodor jordani unicoi, now subspecies

Type:- UF 8162, an adult female, collected along the trail to Haw knob from Whiggs Headow, North Carolina (Graham County)-Tonnesseo (Wonroe County) State line, between 5000 and 5300 reet, on August 17, 1955, by Richard Hohnson and Richard Highton.

Magnosis:- h light-bellied subspecies of Plothodon jordani with lataral white suanophore spots.

Range:- Know only from Whiggs Neadow, haw Knob, listtle Haw Knob, Johns Knob, Stratton Gap, and Beech Gap, at elevations over 4000 feet in the Unicoi fountains along the Tennessee-North Carolina State line (figure 22).

Paratypes:- Greham Ccunty, North Garolinamionroe County, Tennessce State Iine: UF 8162 (18) same data as holotype; UF 8030 (15), Haw Knob Trail; UF 8303 (26), Whiggs Neadow; UF 8306 (B), Little law Knob; UF 8275 (3), 
between Mud Flat and Whiges beadow; UF 8312 (4), UF 8316 (3), Johns Knob; UF 8283, 0.7 miles south of Stratton Gap; UF 8305 (5), 0.9 iniles north of Stratton Gap; UF 8161 (7), 1.3 miles north of Stratton Gap; and UF 8213, 8214 (2), Beech Gap. Tennessee, Monroe County: UF 8310 (2), I mile west of Stratton Gap.

Descriotion of the type in life:- Snout to anterior angle of the vent, $54 \mathrm{~mm} . ;$ snout to posterior angle of the vent, $58 \mathrm{~mm}$; total length, $1 \mathrm{IL}_{4}$ m. 16 costal grooves. 7 vomerine teeth on each side. Lelanophore gaps on chin and between front legs. Numerous small white spots on sides (now faded after preservation). No guanophores on dorsurn, in eye or on eyeiids.

Variation (based on 26 specimens examined in 1ife):- Hine (35\%) possess small dorsal guanophores (as in teyahalee); one has two small red spots on one front leg; $13(45 \%)$ possess small brassy or white flecks on the eyclids; and all but one possess lateral guanophores. The avernge belly pigmentation of this series may be compared with the other races of $\underline{P}$. jordani by referring to table VII.

The costal grooves usually number 16, the trunk vertebrae 17. Vomerine teeth vary from 5 to 12 in a series. A small race, the largest specimen examined is $59 \mathrm{~mm}$. In snout-vent length. Sexual maturity is reached between 40 and $1.5 \mathrm{~mm}$.

Plethodon jordani melaventris Pope and Hairston Plethodion metcalfi Frimley (1912: 139). Fope (1928: 4). Chamberlain (1928: 51). Coker (1939: 10-1). Chadwick (1940: 50). Bishop 1943: $264-6)$. 
Plethodon clemsonae Brimley. Grobman (1944: 293-4).

Plethodon shermani melaventris Pope and lialrston (1948: 107). Hairston and Pope (1949: 266-78). Hairaton (1949: 53). Deevery (1949: 1367-9). Gordon and Sinith (1949: 175).

Plethodion metcalfi clemsonae Brimley. Mittleman (1948: 437). Plethodon jordani melaventris Pope and Hairston. Hairston (1950: 272). Gordon (1952: 679). Schwartz (1953: 156). Howell and Hawldns (1954: 32-6). Howell (1954: 42-3). Hof fman and lubricht (1954: 193). Schwartz (1954: 296-8).

Type:- CNHM 476I4, an adult mele collected at Highlands, Iacon County, North Carolina, at an altitude of 3800 feet, on July 27,1946 , by Alexander Pope.

Diagnosis:- A dark-bellied subspecies of Mlethodon Jordani that typically laclis both guancphores and lipophores.

Range:- Specimens assigned to this form have been reported from swannanoa, Buncombe County (Grobman, 1944, flg. 5), and Burkemont Mountain, Burke County (Hoffman and Hubricht, 1954) south through Polk, Henderson, Transylvania, southern Jackson, and southeastern lacon Counties, North Carolina, and northern Greenville, P1ckens, and Dconce Counties, South Carolina (figure 22).

Description:- The varlation in a series of 138 topotypes has been studied by kowell and hawkins (1954: 32-6). 61 living specimens I have examined from the vicinity of Highlands usualiy lack iridic guanophores (92\%), dorsal guanophores (97\%), and lateral guanophores (82\%), but all specithat possessed these guanophores had them present in very roduced number. In most cases they could be seen only with the aid of a microscope. The 
belly is dark (see table VII), but there is often a reduction of melanophores on the chin, and the chin is almost always wuch lighter than the belly.

The costal grooves usually number 16, the trunk vortebrae 17. Vomerine teeth range from 4 to 17 in a series, tending to increase slightly in number with the size of the animal, as in $P_{.}$. jordani. This is a large race; the maximum size recorded is $78 \mathrm{~mm}$. in snout-vent length (Howell and Hawkins, 1954: 33). Sexual maturity is reached betrreen 50 and $55 \mathrm{~mm}$. In snout-rent length.

Plethodon jordani rabunensis Popo and Hairston

Plethodon shemani Stejneger. Howell (1909: 131).

Plethodon glutinosus (Green). Railey (1937: 3).

Plethodon clemsonae Brimley. Grobman (1944: 293-4).

Plethodon shermani rabunens1s Pope and Halrston (1948: 106-7). liariston and Pope (1948: 274-5). Hairston (1949: 53). Decvoy (1949: 13679).

Plethodon netcalfi clemsonae Brimley. Hittleman (1948: 417).

Plethodon jordeni rabunensis Pope and Hairston. Halrston (1950: 272).

Mype:- CNH 1 17697, an adult fewale, collected at Rabun Bald Mountain, Rabun County, Georgia, on August 3, 1946, by members of the C. H. Pope family, at an altitude between 1,200-4600 feet.

Range:- Known from Rabun, Union, and Towns Counties in northeastem Georyia (rigure 22). Also reported from Habershan County, Georeia, by Liattleman (1948: L18). Specimens from the type locality appear to be Intermediate vetween rabunensis and melaventris. 
Diegnosis:- A derk-bellied subspecies of Plethodon jordani with lateral yellow or white apots. These may be so large that adjacent spots unite to form a continuous lateral band.

Description:- Pope and Hairston (1948: 107) state that in their original series, the chief variation was in the mount of laterel white spotting. They state that $15 \%$ of their specimens lacked the wite lateral and cheek spotting characteristic of this race. However, most of their apecimens were collected in 1939 and had been preserved for a number of years. They epparently exanined only ten specimens in life. I have examined If ving specimens from several localities on the north slope of Rabun Bald Mountain and a large proportion of the specimens possess a small amount of lateral and cheek white guanophore spotting. It is, however, poorly developed compared to specimens of this form from the south and west of the type locality. In the latter, the lateral guanophore pigment is very abundant, and often adjecent spots coalesce into a lateral "band" of yellow or white picment. A small proportion, 2 of 14 ( of a serles of spectnens from Brasstown Bald also have small dorsâl guanophore spots, as in teyahalee.

The costal grooves usually number 16 , the trunk vertebrae 17. Vowerine teeth range from 5 to 13 in a series. This is the largest race, adult specimens approaching the size of glutinosus and yonahlossee. The largest specimen I have examined, from Drasstown Bald, is 82 m. in snout-vent length. Sexual maturity is probably reached betreen 55 and 60 min. in snoutr-vent length. 
Plethodon jordani teyahalee Hairston

Plethodon metcalfi Brimley (1912: 139).

Plethodon glutinosus (Green). Bailey (1937: 3).

Mothodon jordani teyahaleo Hairston (1950: 269-72).

Type:- UMa: 100807, an adult male, collected on Teyahaleo Bald, GrahamCherokee County line, North Garolina, at an altitude of 4525 feet, on August 23 , 1949, by lleison G. Halrston.

Diagnosis:- A dark-bellied subspecies of Plethodon jordani with lateral white or yellow spots, usually with small red spots on the legs, and with very small (0.1-0.3 ma.) white spots on the dorsun.

Range:- Knom from Iuni Gap, Clay-bacon County line; near junaluska Gap, Macon-Cherokee County line; and from Teyahalee Eald in the Snombird Hountains, along the Cherokee-Graham County line, all in North Carolina (figure 22). Intergrades between teyahalee and shemani occur in the vicinity of Aquone, on the east side of the Nantahala Biver, in Nacon County, North Carolina.

Description:- This race is distinguished on the basis of the presence of small dorsal white spots. These are of a different color than those of clemsonae, and resemble the dorsal spots of glutinosus, except that they are much smaller. The moan size of ten spots measured at random in 11 living specimens range from 0.12 to $0.21 \mathrm{~mm} ., \mathrm{wth}$ an average of $0.16 \mathrm{mn}$. The size of these spots is smaller than in any sample of Plethodon glutinosus I have examined. The red spots on the logs are usually not more than $0.5 \mathrm{~mm}$. In diameter. The laterel spots may be yellow or white, and are not as large as those of reburensis from the 
southern portion of its range, although they are conparable in size to those from iabun Sald. The same type of spotting that appears on the sides may also be present on the chin.

The costal grooves usually number 16, the trunk vertebrae 17 . Vonemine teeth vary from 4 to 12 in a serles. The largest specinen examined, from the type locality, neasures $76 \mathrm{ma}$. in snout-vent length. Sexual maturity is apparently reached between 45 and 55 sam. in snoutvent length.

\section{Plethodon jordant clemsonac Brimley}

Elethodon clexsonao Erinley (1927: 73-5). Brimley (1940: 7). Eishop (1941: 20). Bishop (1943: 239-42). Grobman (1944: 293-4). Plethodon shermani clersonae Brimley. Hairston and Pope (1948: 274). Ilairston (1949: 53). Deevey (1949: 1367-9).

Plethodon jordani clensonae Brinley. Leirston (1950: 272). Hairston (1951: 266-74).

Type:- USWM 83849, a male, collected at Jocassee, Oconee County, South Carolina, at an altitude of 1200-1500 feet, by J. A. Berly, on Aprd1 8, 1927 .

Diognosis:- A dark-bellied subspecies of Plethodon jordani possessing numerous small dorsal brassy guanophores.

Range: Inom only from the vicinity of the type locality, Jocassee, Oconee County, Soutb Carolina (figure 22).

Description:- I have examined only six specimens of this subspecies in Iife. There is apparently considerable varlation in the frequency of 
the brassy dorsal spotting. In some specimens it virtualiy covers the dorsum, while in others it is somewhat reduced. This pigmentation contrasts markedly with that on the lower sides, which consists of small guanophore spots. In the specimens I have examined, these were white in color. Presumably this form is similar to melaventris in size, number of vomerine teeth, and costal grooves. Dr. Alvert Schwartz of the Charleston Museum has completed a study of variation in this form and his information should be available in the near future.

\section{Plethodon glutinosus}

This species is the most widely distributed of the Eiastern Large Plethodons. Workers have long realized that $\underline{P}$. glutinosus is quite variable throughout its range. For example, Bishop (1943: 19) states that he believed each of several salamanders, including Plethodon glutinosus, to be " a complex of species or subspecies requiring additional study before its components can be properly delinited." During the last trelve years, three populations of plethodon glutinosus have been described as separate subspecies. The first, $\underline{P} \cdot \underline{\text { P }}$ - albagula, was described by Grobman (1944) based on a serles of light-chinned exanples from the region of the Balcones Escarpment of Texas. In 1949, Allen and Nelll described the populations occurring in southeastem Goorgia and peninsula floride as another subspecies, 5. Erobmanf. In 1951, Mittleman described $\underline{P}$. E. chlorobryonis, based on material fron the Goastal Plain of North Carolina. The range of ench race, as dellmited by the above authors, is quito small, and the romalnder of the specios, including animals from every physiographic province in which this 
species is known, is currently assigned to the typical subspecies, P. E. glutinosus.

The difficultios in studying geographic variation in $P$. glutinosus are mainly due to the fact that much of the apparent vamation in this species, as well as its close relatives, involves pigmentation characters. Host of these pigments are altered by preservatives so that a study of living specimens is necessary in order to obtain accurate information on geographic variation. The recent studies of Hairston and Pope on $\underline{P}$. jordani have shown the value of the examination of living specimens from the entire range of a specier. ithe same method was attempted by the writer with $\vec{L}$. glutinosus, but much greater difilculties are involved in dealing with a species that occurs over most of the eastem United States, from New York and Illinois south to Florida and Texas. Herpetologists from every state in the range of the sling salanander were contacted and inforined of the study and a request was made for living specimens from each region so that animals from the entire range of the species could be compared. A great many interested persons responded to the request and sent me living specimens. As a result, during the last four years, I have examined slimy salamanders from all but two of the states in which it is known to occur. However, there renain many reglons from which I have not had a sufficient number of specimens to obtain a clear picture of the variation within its glutinosus population. Several collecting trips have been made by the writer in order to fill In some of these gaps, but there are so many areas, Includine whole physiographic provinces, from which data on semies of living specinens are not yet available, that the lnowledge of the systematics of this 
species is st1ll fragnentary. It is felt, however, that some progress has becn made and the results, adrittediy tentative and incompleto, are presented below.

In comparing living speolmens from various parts of the range of this species, it is apparent that there is much individual variation within populations, but very $f \mathrm{fw}$ consistent differences are present between animale fron different regions. I have been unable to find any additional characters that vary geographicaliy, other than those previously discussed by Grobman (1944), licill (1948), fllen and Neill (1949), or littleman (1951). All of these characters have boen evaluated using both living and presorved specimens.

P. g. Elbagula is distinguished on the basis of the reduction of the melanophore pigmentation on the chin. As noted by Erown (1950), the characteristic lipht chin of altagula may occur in a few populations of glutinosus in other parts of the range. Specimens with light chins seem to be especially abundant in the Blue Ridge Province of Virginia. The data that Grobman (1944: 283) presents, indicate, however, that the great majority of $\underline{p}$. glutinosus, other than those from Teses, mag be distinguished from albagula on the basis of chin pigmentation. A study of additional material fron Texas, not seen by Grobman, raise additional preblems in connection with the rexas populetions that make it difficult to determine the proper systesatic position of albagula. Those data will be discussed below.

P. G. grobmani was ditagnosel on the tasis of the color and siro of its dorsal and lateral spots, lower costal groove count, and small size. The subspecies, P. g. chlorobryonis was characterized by a ro 
duction of dorsal white spots, the color of the lateral spots, by small "orangengold dots" on the venter, reduced number of vomerine teeth, and smaller average size than other populations of $\underline{P}$. Litinosus.

Thurow (1951) has show that the "orange-gold dots" mentioned by mttleman are actually hecionic glands found in male glutinosus from It: 3 entre range, and the writer has observed the color to change in Individuals that were kept alive for some time, presurably due to the accurrulation of the secretion of the gland. These glands sometimes occur in fenales as well as males, and in both sexes the color ranges from clear or colorless to bright orange. There is saasonal variation. in the colcr of these glands, as well as individual veriation within a population collected at a eingle time, but I have seen no evidence of geogranhic variation in this character.

The range of $\mathrm{P}$. $\mathrm{g}$. chlorobryonis was indic ted by hittleman (2951) to include most of the North Carolina Coastal Plain below the 100-foot contour line. He also believed that the range of this subspeciee elmost certainly extends into South Carolina. Specimens that he considered intemetiate with $\underline{P} \cdot g$. gIutinosus are from the lower Coistal blain of adjacent Virginja, from Granvil.lo and Weke Counties in the Ficdmont of North Garolina, and from Gharleston and Berkeley Counties in the lower Coostal Plain of South Carolina.

Schmidt (1953: 34) has recent3y restricted the type localities of tpo symoryis of P. Elutinosus, Salanandra varlolata Gilinam (1818), and Salamandra cylindracea Harlan (2825), tn Charicston, South Carolina. Salamandra variolate was originally described as inhabiting the "gouthern states," but Gilliams $(1818: 461)$ states that the specinens on 
which the description of $\underline{\underline{s}}$. variolata were based were recelved from the "Forida larty." Since they were apparently collected by a person residing in Florlda, or an expedition to Florida, this state would appear more likely to be the type locality of $\underline{S}$. variolata than South Carolina.

Harlan (1825) states that the specinens on mich he based the descriftion of Salamindra cylindracen were sent to hin by $\mathrm{Dr}$. Blanding of Camden, South Carolina, who collected other herpetolo gical specinens referrel to in the sare paper in the vicinity of Camden, South Carolina. Camdon would therefore be a better choico for a restricted type locality thas Charleston, South Carolina.

Allen and Neill (1949) give the range of P. E. Grobmani as "from northern Emanuel and Screven counties, in the Georgia Costal Plain, gouthward to Finellas and Hilsborough counties, Forida, eastward to the Savannah Piver in Ceorgia, and westward approxdmately to the eastem border of the Dougherty Plain in Georgia." This would include Savannah, Chathan County, Georgia, within the ranse of $\mathrm{P} \cdot \mathrm{g}$. grobmani. Indeed, specimens from adjrcent Efringham County, Georgia, are designated as paratpues of this form. If this is the actuai range of grobrani, then this name is preoccupled by Salamendre albopuncteta Vallenciennes (in Dumeril and Bibron, 1854), type locality, Savannah, Georgia. Vallenciennes also described Salamandra elongata in the same paper in wich he described S. albopunctata, but failed to designato a type locality. This form was also probably based on specimens from the southeastem Coastal plain, but it will probably never be necessary to designate a type locality for $1 t$, as there are several earlier names available for southeastem Coastal Plain P. glutinosus. 
There are, then, s1x names avatlable for the Plethodon glutinosus of the scutheastern Coastal Plain:

Salmandra variolata Gilliams, 1818 (type locality, probacly Forida).

Salamandra cylindracea Harlan, 1825 (type locality, prokably Canden, South Carolina).

Sal amandra albopunctata Valenciennes, 1854 (type locality, Savannah, Georgia).

Salamandra elongata Valenciennes, 1854 (type locality not designated).

Plethodon glutinosus grobmani Allen and Ne1ll, 1949 (trpe locality, Half-mile Creek Swamp, about one-half mile northeast of Silver Springs, Narion County, Florida.)

Plethodon glutinosus chlorobryonis littiemen, 1951 (type locality, 13 miles north of Hew Berm, along U.S. Highway 17, Craven County, North Garolina).

The subspecific identity of sevoral Coastai Plain poprilations of P. Elutinosus must be determined in order that, the nane Balamandra variolata, winch has priority over all the other more recent nares, can be correctly assigned. In order to attempt to correctly apply the above names and to detemine the number of valid subspecies of glutinosus in the Atlantic Coastal Plain, living specimons have been obtained fron the typo localities, as well as from many other places in the region. The characters studied illl be annlyer: separately below.

Number of costal grooves:- Doth Allen and Neill (1949: 112) and intttemas. (1951: 11) stute that in southeastem Coastal Plain, . glutinosus possesses one or tiro costal grooves less than more northern populations, 
which usually have 16 costal grooves. Data on the number of costal grooves and trunk vertebrae in several georraphic samples of $\underline{P}$. glutinosus are given in table VII. Tn avoid counting the same characteristic (number of boty segments) twice, costal groove counts are not included in the table for any of the specimens for wich vertebral counts are listec.

The modal number of trunk vertebrae in each sample $1 \mathrm{~s} 17$ and the corresponding number of costal grooves is 16. The only variation appears to be in the persontage of individuals with one segment more or less than the mode. In tho Texas sample, $11(8 \%)$ possess 18 vertebrae, and there are none with 16 vertebrae. On the other hand, in the southeastom Coastal Plain, there is a silght tendency to possess one less segment than the modal number. Radiographs indicate that 9 of 22 (4I\%) specimens fron peninsula Florida have 16 trunk vertebrae, but this is apparentiy an unusual sample, for only 20 of 150 (13\%) additional specimens have 15 costal grooves. These slight differences may indicate the beginning of differentiation in the populations concemed, but the differences are not of the magnitude claimed by previous workers.

Size:- Both AIIen and NeIII (1949: 112) and 14ttleman (1951: 111) noted the reduction in size in southeastern Coastal Plain glutinosus. Size is a difrlcult character to analyze in cold-blooded vertebrates, unless large series of specimens are avaliablo, so that en ascurate estimation of maximum $3 i z e$ or size at maturity can be obtained. Another difficulty results fron the fact that the average size of mature animals varies from season to sebson, for as the group of immature aninals begins to mature, the agerage size of sexually mature adults $w 111$ be lowered. As growth continues, the average size of mature animals will increase 


\section{TABIE VIII}

GEOURAPHIC, VAKIAIION IN BODY SFGMNDATION OF PLETHODON GLUTIHOSUS

\begin{tabular}{|c|c|c|c|c|c|c|}
\hline \multirow[t]{2}{*}{ Locality } & \multicolumn{3}{|c|}{$\begin{array}{c}\text { Number of ccetal } \\
\text { grooves }\end{array}$} & \multicolumn{3}{|c|}{$\begin{array}{c}\text { Number of trumk } \\
\text { vertabrae }\end{array}$} \\
\hline & 15 & 16 & 17 & 16 & 17 & 18 \\
\hline
\end{tabular}

Coastal Plain:

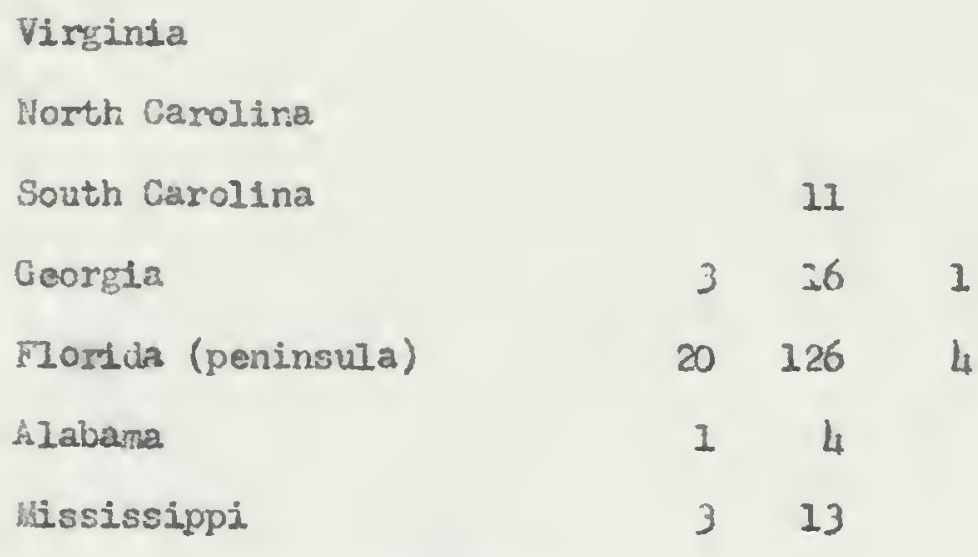

$425 \quad 1$

$3 \quad 7 \quad 1$

$215 \quad 2$

Other phvsiographic provinces:

Nen York

16

Nen Jersey

2

Pennsylvania

Haryland

1

1

Virginia

14

18

North Cerrolina

131

South Carolina

Georgia

142

Onio

5

Kentraky

16

Tamesse

1315

A rkansas

1271


throughout the reminder of the year. That this factor is important In Florida P. Elutinosus was shom ky the rritar (in press). As yet we have very little howledge of the life history of 1 . Glutirosus in other parts of the range and have no basis on which to make comparisons of the avorage size at moturity. In Florida, in the fall, mcst specimans ovor $45 \mathrm{~m}$. In Iength are mature, wheress in the sumer, most under $55 \mathrm{~mm}$. are imature. I lave examinad mature spocimens of ?. Elutinosus from the southern hppalachian hountains that were betreen 45 and $50 \mathrm{~mm}$. In snoul-vent length. At present, there is no evidence to support the contention that there is a difference in size at maturity between Forida and Appalachian mountain P. GIutinosus. This does not rule out the possibility that differences in size at maturity between different populations do exist, but, more information on the life history of this species outside Flomida is needed to confirm this premiso.

The maxtrum size of over 700 peninsula Florida specinens that I have measurei is $69 \mathrm{~mm}$. in snout-vent Iength (bafore proservation). The largest Virétinia Coastal Plain specinan I have neasured is 72 жm. in snout-vent length. (after several years of preservation). In mall samples from many other localities in the range of this species (Texas, Indiana, Now York, Naw Jersey, Pennsylvania, Varyland, and the Pisdinont and Elue Eidge Provinces of Virginia, North Carolina, South Garolina, and Gsorgia), specimens between 70 and $80 \mathrm{mr}$. In snout-vent length are common, and the larest spectmm examined (UF 8112, collected 5.2 miles south of Sunburet, Haywood County, llorth Carolina), a male, res $86 \mathrm{~mm}$. in snout-vent lenth before preservation. Clearly, the maxdmin size of penins:lla Florida glutinosus is less than most other populations, but maximum size objously cannot be use- as a systematic character with 
which to assign or Ldentify individual secimens.

Vomerine tecth:- rittienan (1951: 109) publishod the vomerine tocth counts on the type series of $\mathrm{P}$. $\mathrm{g}$. chlorobryonis. He pointed out that they were much lower than most counts on P. P. Elutinosus. He also suggester that the vomerine count in gmbmani micht be expected to be even Iower than those in chlorobryonis. Vomerine tooth counts were made on 32 specimens from the Coastal Plain of Virginia, 13 specimens Prom the Coastal Plain of North Carollna, and 269 specimens from peninsula Florida. The data obtained are shom in figures $I_{4}$ and 15. In addition, the series of 125 specimens that Fope and Pope (1248) used in their study of this character in montane Virginia glutinosus mere also exanined by the writer. in counts on this series were essentially the same as the Popes' counts. It is obvious that adult Coastal Plain Virginia and Horth Carolina specimens have fewor vomerine teeth than either peninsula Horida or Virginia mountain spectmens. An examination of the figures shows another difference between the three populaticns. In each sample thare is an ontogenotic increaso in the nunber of vomerIne teeth. $\Delta$ t-test on the difference between the rate of increase (slope) of the equations for the Virginia mountain and lorida samples, shows that the probability of obtaining a difference as great or greater than that observed by chance alone is less than .0901. In spite of this sinnificant iffference in the rate of increase in the number of testh with growth, there is wide overlap in the number of teeth in similas size groups of the two populations. In the Coastal Plain Virginta and North Carolina samples, there is a further reduction, both in nuriter of teeth and the rate of increase with growth. Some slight overlap between the Virginia mountain and Coastal Plain Virginia and Horth Carolina san- 
ples remain, although a majority of adult specimens of each fom could be segregated by a striaght line separating the dots representing the tro populations. For example, a line passing through the point (snoutvent length $=45$, vonerine teeth $=16$ ) and the point (snout-vent length $=70$, vomerine teeth $=18$ ) would separate 69 of $75(92 \%)$ Virginia mountain specimens $45 \mathrm{~mm}$. and over in length from 33 of 35 (94\%) Coastal Plain Virginia and North Carolina specimens $45 \mathrm{~mm}$. and over in length. The condition in samples from the Virginia Pledmont is unknown, but the intermediate Florida sample shows wide overlap with both of the above samples. A significant biological difference betreen the $\underline{P}$. glutinosus of the three areas is obvious, yet this character could hardly be used as a key character to separate either of the Coastal Platn samples, or tho Florida and the Virginia mountain samples into separate subspecies. The observed differences in the number of teeth may be the result of a gradual clinal change that is not usually recognized by the systematist as a basis for orecting subspecics.

Size of dorsal spots:- The size of the dorsal spots of living or freshly preserved specimens was measured with the aid of an ocular micrometer (1 micrometer unit $=0.0685 \mathrm{~mm}$. ). Since the size of the dorsal spots increase with growth, the ratio of the average size of ten dorsal spots chosen at randorn to the snout-vent length was used as a basis of compar ison. Specimens of different lengths in the same sample usually show similar ratios when compared in this manner. The data obtalned are shown in table IX.

It is apparent that in the Atlantic Coastal plain thero is a decided decrease in the size of the dorsal spots from north to south. There is wide overlap between every adjacent population and nowhere is 
TAETE IX. CECORAPHC VARTATION IN DORSAL SPOT SI\%H OR P. GLUTINOSUS

\begin{tabular}{|c|c|c|c|c|c|c|c|c|}
\hline \multirow{3}{*}{ Locality } & \multirow{3}{*}{$\begin{array}{l}\text { Ratio } \\
1.0-9 \\
4.9\end{array}$} & \multirow{2}{*}{\multicolumn{3}{|c|}{$\frac{\text { Nean Spot Size }}{\text { Snout-vent length }}$}} & \multirow{2}{*}{\multicolumn{2}{|c|}{$-2 \times 100$}} & \multirow[b]{3}{*}{$\begin{array}{l}\text { over } \\
25.0\end{array}$} & \multirow{3}{*}{$\begin{array}{l}\text { Actual } \\
\text { mean } \\
\text { (not } \\
\text { grouped) }\end{array}$} \\
\hline & & & & & & & & \\
\hline & & $\begin{array}{l}5.0- \\
8.9\end{array}$ & $\begin{array}{l}9.0- \\
12.9\end{array}$ & $\begin{array}{l}13.0= \\
16.9\end{array}$ & $\begin{array}{r}17.0- \\
20.9\end{array}$ & $\begin{array}{r}21.0= \\
24.9\end{array}$ & & \\
\hline \multicolumn{9}{|l|}{ Coastal Plain: } \\
\hline Virginia & 2 & 12 & 1 & 1 & & & & 7.2 \\
\hline North Carolina & 1 & 7 & 5 & & & & & 8.3 \\
\hline South Carclina & & 3 & 12 & 2 & 1 & & & 11.1 \\
\hline Georgia & 1 & 2 & 12. & 4 & 8 & 3 & 3 & 15.7 \\
\hline Floridz (Peninsula) & & 1 & 7 & 10 & 16 & 10 & 2 & 17.9 \\
\hline Iorida (Pantandle) & & & 1 & 4 & 3 & 11 & & 20.5 \\
\hline Alabame. & & & & 2 & 1 & 2 & & 19.5 \\
\hline Mississippi & & & 1 & & 1 & & & 14.6 \\
\hline Louirtana & & & & 1 & & & & 14.3 \\
\hline \multicolumn{9}{|l|}{ Other Provinces: } \\
\hline Hew York & 1 & 1 & & 1 & & 1 & & 12.9 \\
\hline New Jersey & & & & & & 1 & 1 & 24.5 \\
\hline Pennsylvania & & & & 1 & 1 & & & 17.7 \\
\hline varyland & & & & & 1 & 2 & & 22.6 \\
\hline Virginta & & 1 & 2 & 4 & 3 & 2 & 1 & 16.8 \\
\hline \multicolumn{9}{|l|}{ Morth Carolina } \\
\hline Pleimont & & & 4 & 7 & 1 & & & 13.5 \\
\hline Ilue Ridge & 1 & 12 & 18 & 5 & & & 1 & 10.4 \\
\hline South Carolina & & 1 & 7 & 14 & 5 & 1 & 1 & 15.1 \\
\hline Georgia & & 1 & 1 & 3 & 2 & 1 & 1 & 16.5 \\
\hline Tennessee & & & 7 & 7 & 6 & 3 & 2 & 16.8 \\
\hline hest Virginia & & & & & 1 & 1 & & 22.2 \\
\hline Indiana & & & 1 & 4 & & 2 & & 17.4 \\
\hline Texas & & 8 & 2 & & & & & 8.6 \\
\hline
\end{tabular}


there apparent an abrupt change from small to large spots. This character, at least in the Atlantic Coastal Plain, would appear to represent an internal cline. There is not sufficient material available from the Gulf Coastal Plain, except for west Florida, to determine whether or not there is another decrease in the size of dorsal spots to the west. In other parts of the range of glutinosus, from which raterial is available, the average size of the dorsal spots appears to be fairly large, except for Texas and North Carolina specimens. In North Carolina, the average size of the dorsal spots for 12 specimens from the Piedmont is 13.5 , while the average size of 37 specimens from the Blue Ridge Province is 10.4 . The available specimens would not support the contention that there is a wost to east reduction in oize of spots toward the Coastal Plain, since the Fledmont series has spots averaging slightly larger than those in the mountains.

One of the diagnostic characters given for chlorobryonis is the small size of its dorsal spots. Unquestionably, the size of the dorsal spots of specimens from the Coastal Plain of Virginfa and North Carolina is much reduced. This reduction is approached by specimens from Texas, the Blue Ridge Province of North Carolina, and the Coastal Plain of South Carolina. Because of the clinal nature of the variation of this characteristic in the Coastal Plain, it cannot be usod as a systematic character to separate the North Carolina and Virginia populations of Coastal Plain glutinosus from the remainder of the species, although it may be considered evidence that these populations show fur ther biological differences from many other populations of glutinosus.

All but one of the specimens in the Coastal Plain Virginia 
sample are well-preserved specimens in the Camegie kuseum Collection. The one living specimen has a mean spot size to snout-vent length ratio of 6.4, lower than most North Carolina Coastal Plain specinens. In the preserved Carnegle lusour serles, only the dorsal spots of specimons in which they are well-defined and clearly visible are included, so that they are almost certainly comparable to the living material on which the remainder of the table is based.

One of the characters that Allen and Ncill (1949: 112) used to diagnose $\mathrm{P}$. . . Erobmani was "back with tiny scattered dots of a metallic golden color." Datz on the geographic variation of the color of dorsal spots will be given belov, but it is obvious that the size of these spots in populationg from the Coastal Plain of Georgia and Flowda are well wi.thin the range of many other populations of $P$. gutinasus.

Color of dorsal spots:- The color of the dorsal spots is one of the diagnostic characters used in the original description of $P$. by AIlen and Neill (1949: 121). The dorsaI spots of specimens from southeastern Georgia and northern peninsula Florida were deacribed as a "metalific golden color." This character was descrived as being the most consplcuous diagnostic feature of $\mathrm{P}$. $\mathrm{g}$. grobmani. It is true that a very large proportion of specimens from the range of probmani possess dorsal spots containing a large proportion of brassy guanophores. This type of dorsal spotting is not restricted to specimens from this area, however. Sinclair (1950: 200) pointed out that specimens from Shelby Courty, in westem Tennessee, possess dorsal spots that are similar in color to those described for grobmani. I have examined Iiving speci- 
mens with as heavy brassy flecking as occurs in topotyic grobmani, from many localities outside its range as defined by Allen and Nesll. Specirans in this category were collected in the Pledmont of Coorgia (Fulton County); the Blue Ridge Province of Ceorgia (Nurray and Gilmer Counties); the Blue Ridge Province of Tennessec (Nonros County); Greene County, Now York; Pike, Nonroe and Alleghany Counties, Pennsylvania; as well as many localities in the Coastal Plain of Virginia, North CaraIina, South Carolina, western Florida, southwestern Goorgla, Alabama, and lississippi. In some of these localities, only an oceasional specimen shows a heavy amount of brassy flecking (e.g. the Now York, South Carolina and the Georgia Piedmont samples), but in most of the other localities mentioned, it is the usual condition. This is especially true of specimens from southeastern Tennessee and Potato Patch Bountain, Murray-Gilmer County line, Georgia, where many individuals exceed the usual peninsula Florida glutinosus in amount of brassy flecling.

In spite of the fact that the presence of brassy flecking is not linited to certain southesstem populations, thare is considerablo ovidence that it does rot occur throughout the entire range of this species. I have examined more thar a dozen living specimens from single localities in the Blue Ride Province of Virginia, North Carolina, and northeastern Tennessce, as well as the Fledmont Province of Ilorth Carolina and South Carolina. In most of these specimens the brassy flecking was extremely reduced or absent and in only about $10 \%$ was there a moderate amount of brassy flecking present. In other localities from which I have studied nore than a dozen specinons, the usual condition appears to be intermediate, with a moderate amount of dorsal brassy 
flecking. $\underline{P}$ - Mlutinosus of this type have been exalined from central New Jersey (including the sicinity of Princeton, the type locality of P. glutinosus); Cataraugus County, New York; iandolph County, lest Virginia; Giles County, Virginia; the Piednont of Georgia; and eastern Oklahoma.

An objective method of compring the color of dorsal spots of specimens from different localities was necessary before geographic variation in this character could be successfulty analyzed. Two methods were used, both of which have certain advantages and limitations. The first was to compare the actual color of the dorsal spots with a stancard color guide. Villalobos and Villalobos (1947) has a decided advantage for analyses of this type because the giots may be compared directly with the color through a sirall hole punched in the center of each color. In this manner the color (to the naked eye) of the spots of specimens frol difforent localitics could be compared with a standard. The same person made all the comparisons under uniforn light conditions and the possibility of unconscious blas was reduced by the fact that the person waking the conparisons was not iniormed of the geographic provenance in which the specimens were collected. A disadvantage of this method is due to the fact that specimens with different sized spots, or individuals in which the white guanophore pimentation vas less concentrater, would often.appear different in color, although the actual amount of brassy guanophore flecicing was similax. To get around this difficulty, a parallel stuty of the pigmentation was ade with the aid of a dissecting microscope. 
Specimens that were obtalned from various parts of the range were aintained alive in a refrigerator at a temperature of about $11^{\circ}$ c. At this terperature, adult Plethodon can survive for a year or tro with a moderate amount of care and fecding. The maintenance of a collection of living specimens of this species was necessary in order to compare living specimens from different localities that could not be obtained alive simultaneously. Some loss of material before it could be thoroughly studied occurred, and as a result, a number of specimens that were casually studied on their arrival could not be included in some of the data in the tables because accurate notes on their color or pigrentation were not taken.

The data on the color of dorsal spots indicatea large amount of rariation in this character in specirens from a single locality. Three characteristics are measured using Villalobos and Villalobos' color guide. These are hue, lightness value, and degreo of chrowaticity. Essentially these measure the color, lightness or darkness, and intensity of the color. All three readings were taken from the spots of a given specimen. One way to analyze individual or georram phic variation is to compare oach messured guality separately.

The coior of dorsal spots in P. glutinosus varies from SSO to E (see Villalobos and Villalobos, 2947, for the meaning of the symbols used here), and in addition there are some individuals in which color is lacking (see table $X$ ). In specimens in wtich the dorsal spots appear brassy to the naked oye, the color characteristically ranges from 0 to YYO. There appears to be Ifttlo difference in color in samples wth reciuced brassy and those in which the brassy 


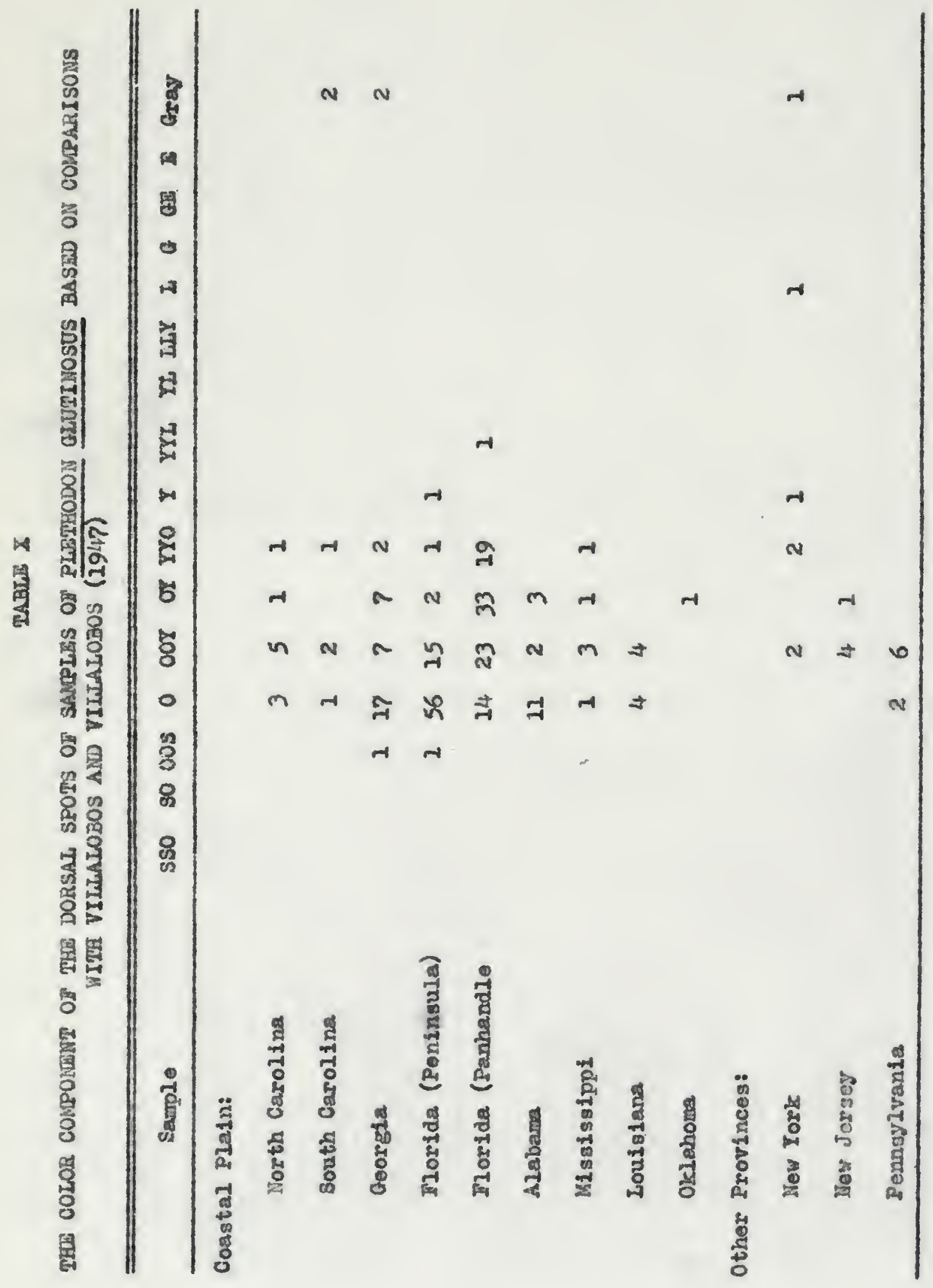


pigment is abundant. In samples in which the trassy pigment is absent or very reduced (Virginia, North Carolina, and Couth Carolina Pledmont and Alue idfpe specinens) there is a tendency for the color to be slightly more green (usual rangs O to LLY) as well as a high percentage of specimens whet do not show any color to the naked eye. There is wide overlap in the color of spots of specimens in which the brassy pigment is present and those in witich it is absent, but the essential difference in the absence of color in those individuals that have white spots is often detected by this method.

The lightness value ranges from 10 to 20 (see table XI), with very little difference between sumples from different regions. The sample means vary from 14.5 to 19.0 with no apparent geographic trends. A significant difference may exist between semples with or without brassy flecking, but such a wide overlap exists betwecn the two samples that this character is of little value in jistinguishing between the two types.

There is considerable variation in the degree of chromaticity, or intensity of the color, in the various samples (see table XII). The entire range is from aray to $9^{\circ}$. In this character, there is a decided geographic variation, the brassy flecked populations showing a much greater amount of color than those that usually lack the brassy-type guanophores. It would be difficult to identify specimens on this basis, although there is a significant difference between the two (cf. the Piedmont and Blue indge Virginia, fiorth Carolina, and South Carolina samples with the Georgia, Florida, and Alabama Coastal l'lain samples). The Tennessee sample is made up entirely of specinens of the brassy 


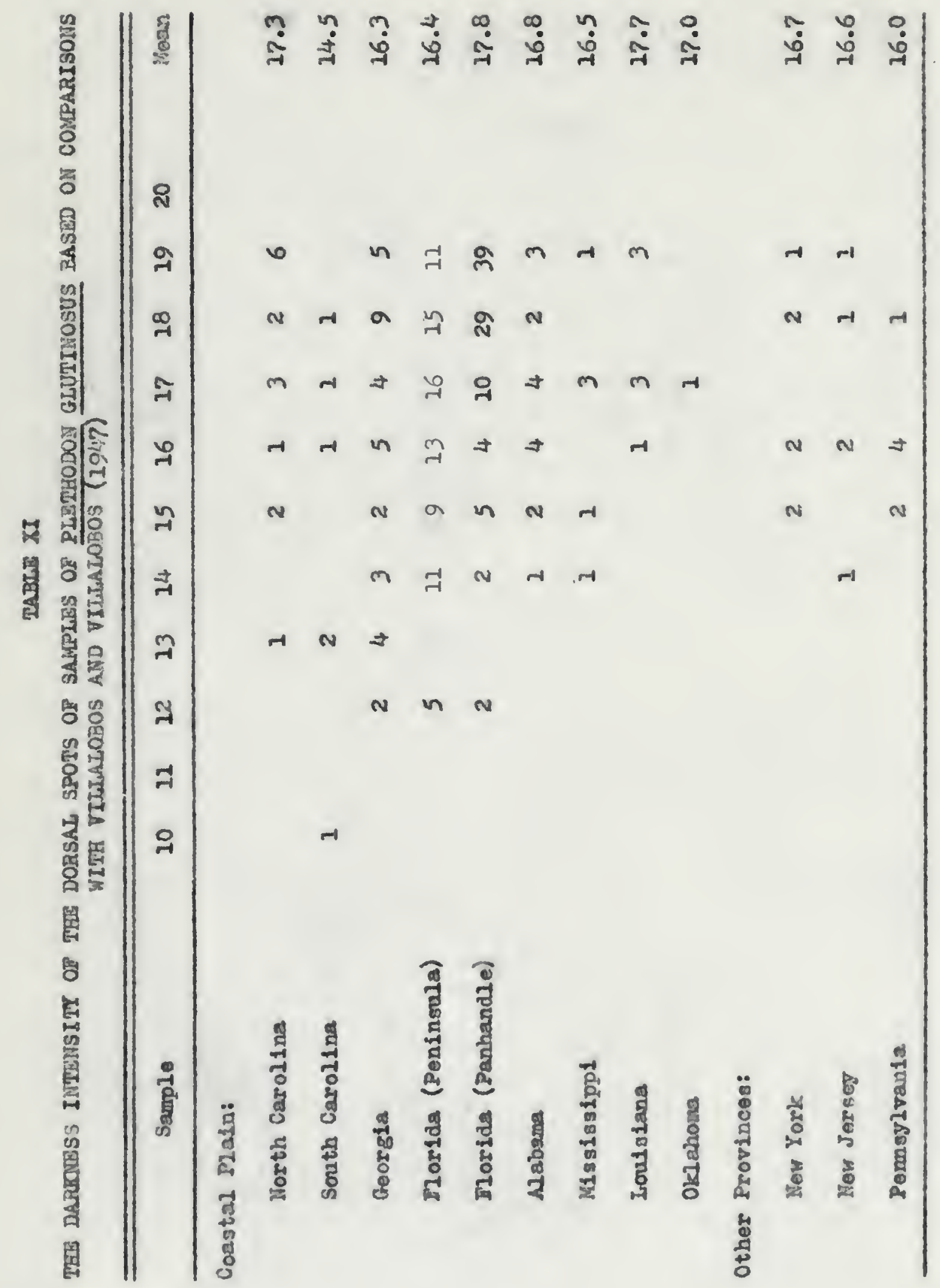




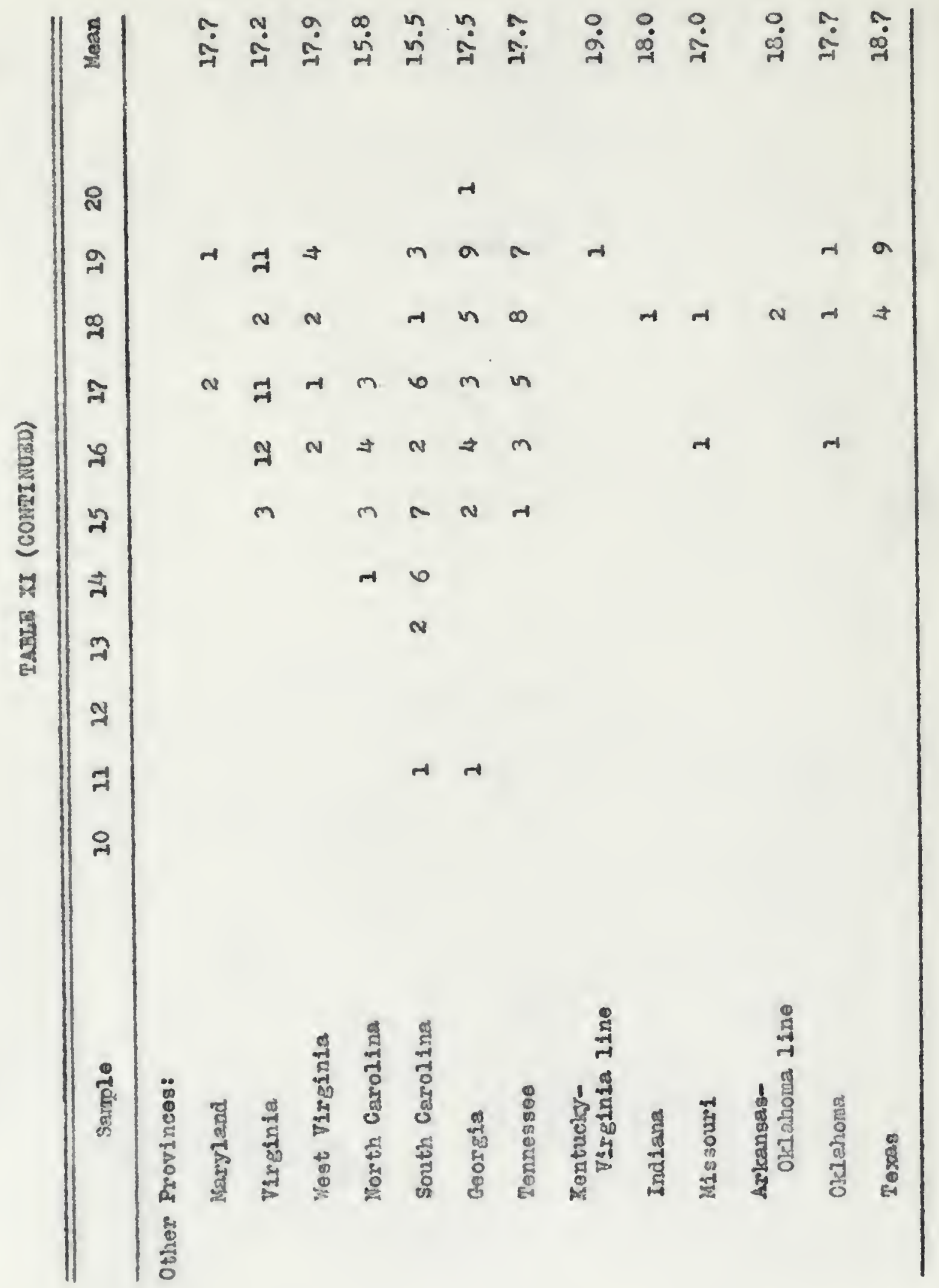




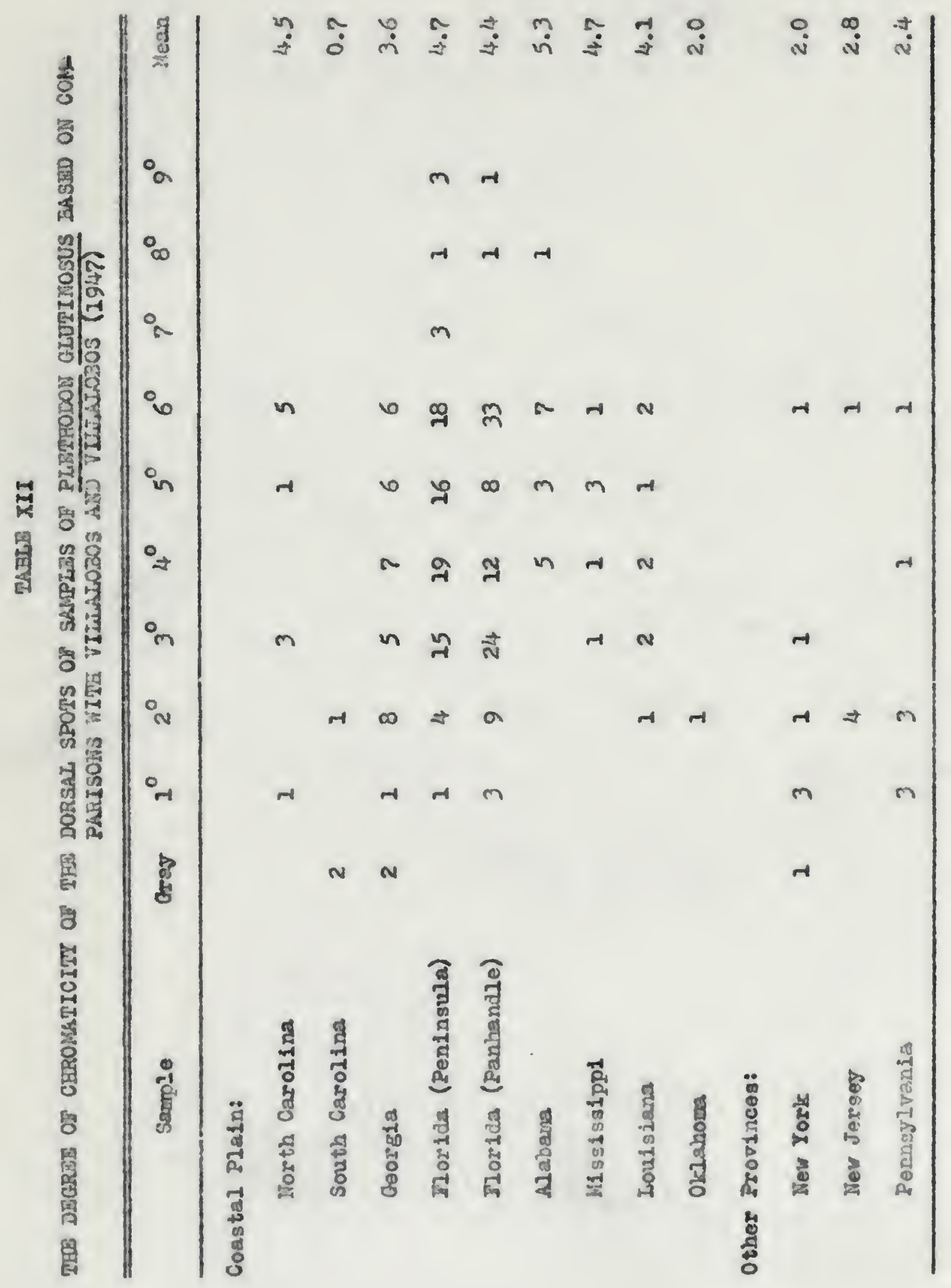




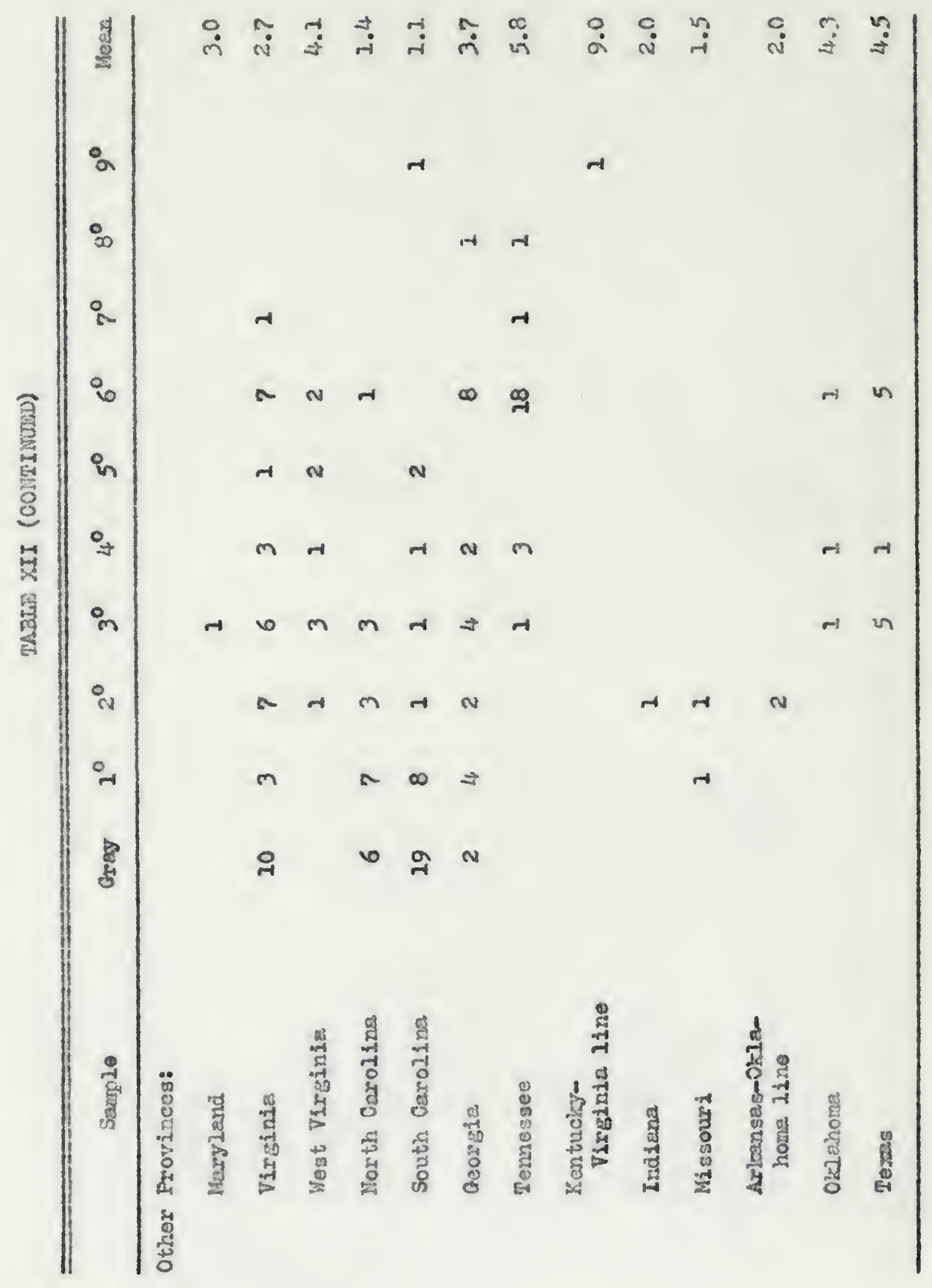


flecked type, and the Georgia Piedmont and Ilne Idge sample includes both types.

The results of the exmination of the actidal spots under the magnification of a dissacting microscope shov a variation that corresponds to the data obtained fro. co Tyarisorm we with the color charts. The reakness of these data lies in tie roc, that the assign ment of specimens to each category was some hat suijective. The specimens I used for standerds are not frescrved ind so it will be impossible for other workers to repeat the wolk without obtining living specimens from the localities from which injividusls were used as a basis of comparison. I chose a tyricul specinen from Torreya State Park, Liberty County, Florida, as an era jule of in aniaal with a large amount of brassy flecks in each clorsal wite erat. A specinen from 5 miles east of Davidson, Cabarrus Couty, lomil Carolina, was chosen as the other axtrene, completely lacling 'msey flecks in the dorsal spots. Specimens that showed a very slight im unt of brassy pigment, usualiy at the borders of the dorsil wite s! nts were regarded as "slightly brassy." Others, that had a codnrats ino $t$ of brassy flecking in the thite spots were placed in ar interne iste category. In a few specimens, usually those with very small siots, no white guanophores could be seen, only the brassy tyro were present. These were included und $r$ the heading, "brassy onl." 2 .est lata are surmarized in table XIII (nost of the spocimens fron t nrocssee included in this table belong to the white-spotted northastmm 'ennessec sarple rather than the southeastern Tennessee brassj-s, ottel population). 


\section{TABIE XIII}

GBOGRAPHIC VARIATION OF DORSAL PIGMETTATON IN PLFTHODON GLUITNOSUS

\begin{tabular}{|c|c|c|c|c|c|}
\hline Semple & $\begin{array}{l}\text { Thite } \\
\text { only }\end{array}$ & $\begin{array}{l}\text { S1fghtly } \\
\text { brassy }\end{array}$ & $\begin{array}{l}\text { Hoderately } \\
\text { brassy }\end{array}$ & $\begin{array}{l}\text { Heavy } \\
\text { brassy }\end{array}$ & $\begin{array}{l}\text { Brassy } \\
\text { only }\end{array}$ \\
\hline \multicolumn{6}{|l|}{ Coastal Mlain: } \\
\hline Birginia & & & & & 1 \\
\hline North Carolina & 3 & 3 & & & 11 \\
\hline South Carolina & 5 & 5 & 4 & 3 & \\
\hline Georeia & 5 & 16 & 10 & 11 & 5 \\
\hline Florida (Paninsula) & & & 4 & 25 & 5 \\
\hline Florlda (Fanhandle) & & & 1 & 14 & 1 \\
\hline Alabama & & & & 6 & \\
\hline Mississippi & & 2 & & 4 & \\
\hline Louisiana & & & & 2 & \\
\hline \multicolumn{6}{|l|}{ Other Provinces: } \\
\hline Hew York & 1 & & 2 & & 1 \\
\hline New Jersey & & & 3 & & \\
\hline Pennsyl vania & & & & 5 & \\
\hline laryland & & & 3 & & \\
\hline 霞est Virginia & & 1 & 1 & & \\
\hline VIrginia & 11 & 5 & & & \\
\hline North Carolina & 24 & 21 & 5 & & \\
\hline South Carolina & 11 & 12 & 4 & & \\
\hline Georgla & 1 & 7 & 3 & 4 & \\
\hline Tennesseo & 1 & 16 & 4 & 4 & 2 \\
\hline Missouri & 2 & & & & \\
\hline Oklahoma & & 1 & 1 & 1 & \\
\hline Texas & & 20 & & & \\
\hline
\end{tabular}


are difficult to interprot because of the paucity of material from a great many areas. The only large series are from the southeastem states. The condition in the northeastern portion of the range of glutinosus aypears to be more similar to that of Florida specimens than it is to the color of Pledmont and Blue Ridge specimens from Virginia, North Carolina and South Carolina. The data are sufficient to refute Allen and Neili's suggestion that the brassy condition is limited to Georgia and Florida Coastal Plain specimens, for most individuals from New York, New Jersey, Pennsylvania, northern Georgia, and southeastern Tennessee have a moderate to large amount of this type of flecking. Whether the Pledmont and Blue PIdge specimens from Virginia, North Carolina, and South Garolina aro different enough from aninals in the remainder of the range to warrant nomenclatorial recognition on the basis of this character reinains to be determined. This may be the case, but a study of much more material from the northern and mid-western states is needed before a decision can be reached with any degree of certainty.

Abundance of laterel pigment:- Grobian (1944: 282) has pointed out that there is a north-south cline in the anount of white lateral pigment in this species. Specimens from the southeastem Coastal Flain have large lateral spots and in many actults the spots coalesce to form a lateral band of white pigment. Specimens from the oouthem Appalachians show a reduction in the slze of the lateral spots, and farther north, the lateral spots are no larger than those on the dorsum. Grobman also pointed out that some Texas specimens possess a large amount of lateral plgment that forms a band on the sides of adults. 
One other difference has been noted in the lateral pigmentation of glutinosus in the northern portion of its range, corpares to southern spectmens. In a large proportion of animals from llew York, New Jersey, Pennsylvania, laryland, and Vest Virginia, the pigment in the center of lateral spots seems wuch more concentrated than that on the edges of the spots, whereas in the south, where the spots are usually largor, tho pigment is more eveniy distributed. This character is probably also clinal in nature, but has not been analyzed in detail.

It is difficult to measure and evaluate the size of the laterel soots, since two adjacent spots lose their identity as they suse during growth. I have not made measurenents of the size of latoral spots, but superficial examination of specimens from different rectons confims the observations of eariler workers. The lateral band secms to be nost prevalent in specimens from the Virginia, North Carolina, and South Carolina Constal Plain, as well as some Texas populations. Allen and Neill (1949: 13.3) report that specinens fron Burko, Jefferson, Washington, Glascock, and Richnoni Counties, Georgia, also have an abundance of white pigment on the sides. I have not examined liting specinens from any of these counties.

Color of lateral pigment:- The color of the lateral spots was used as a dignostic character in the original descriptions of both grobmani and chlorobryonis. The lateral spots of grobmani wore described as being grayish, wile those of chlorobryonis are described as being greenish-white or yellow-green. A study of the color of the lateral spots similar to trat made on the dorsal spots is sumarized in tables XIV, XV, and XVI. The data on comparisons of lateral spots with 


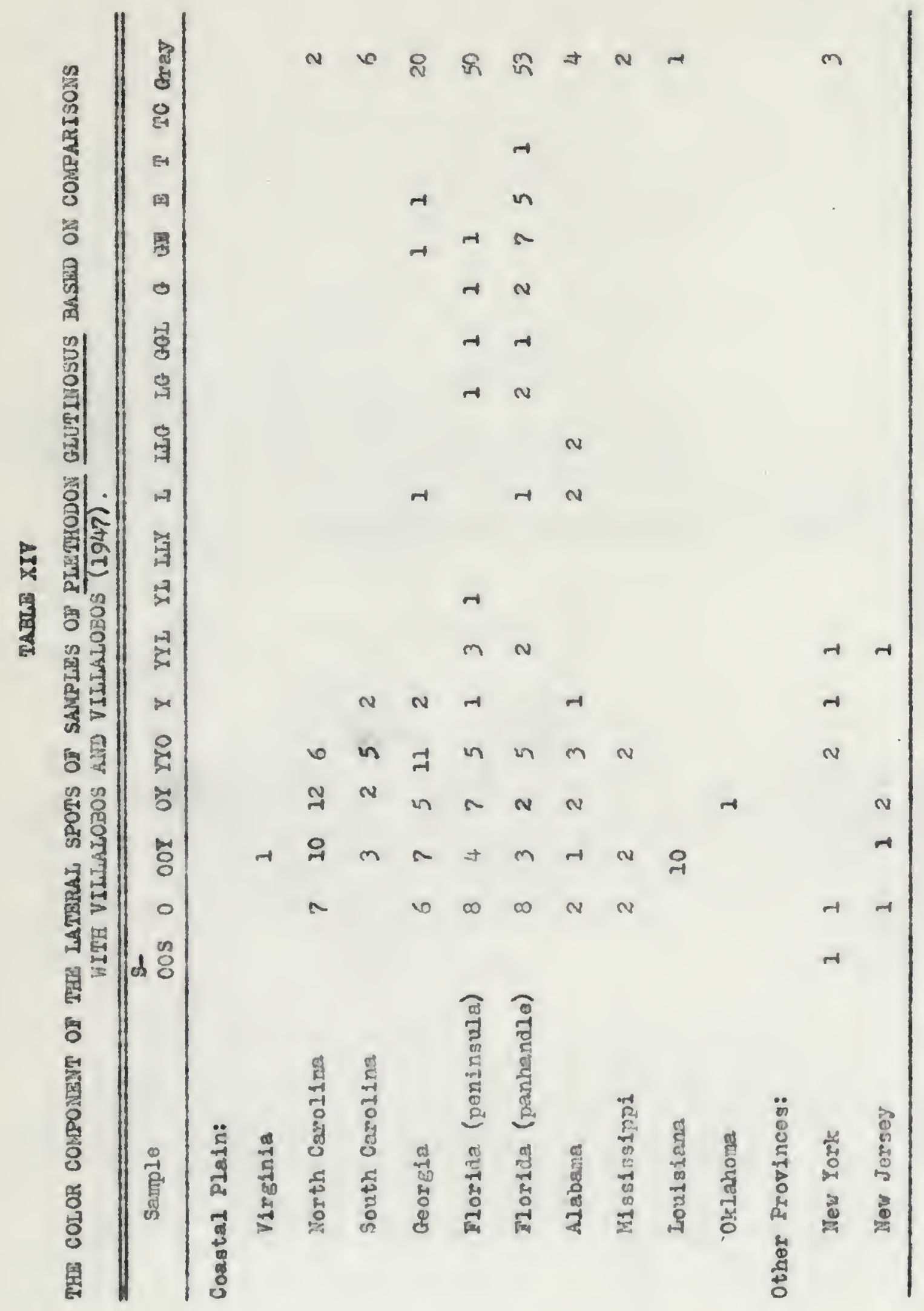




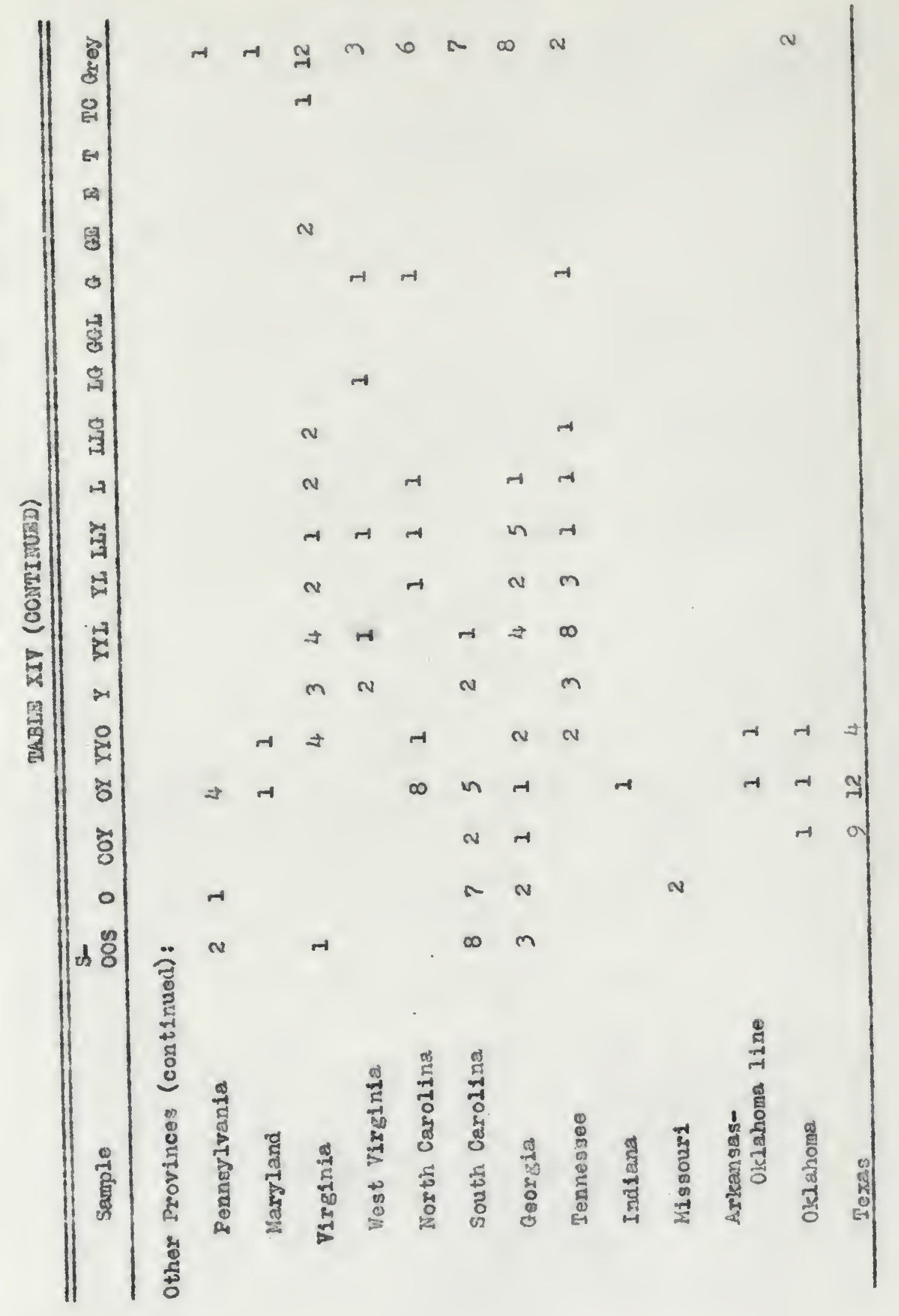




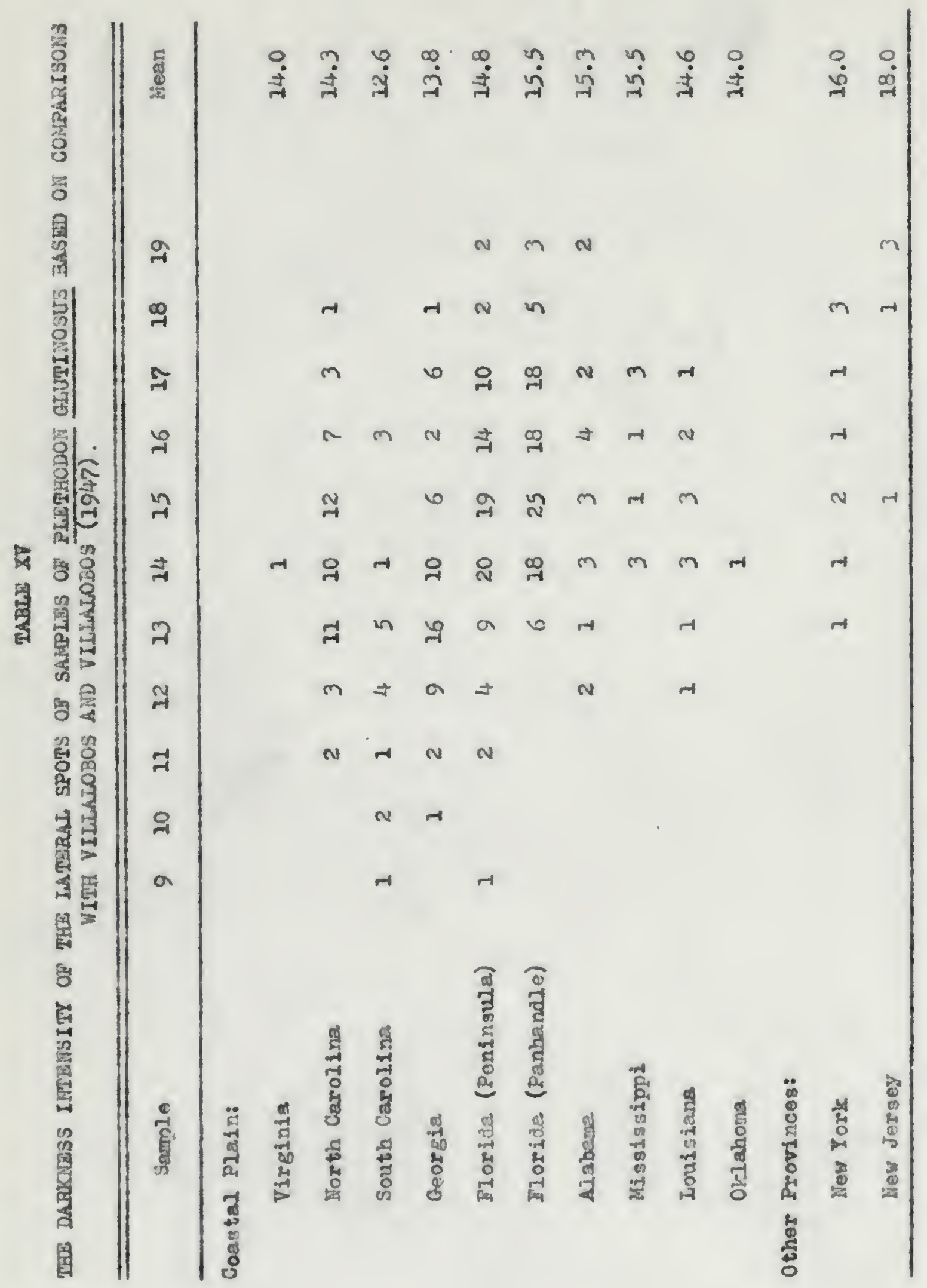




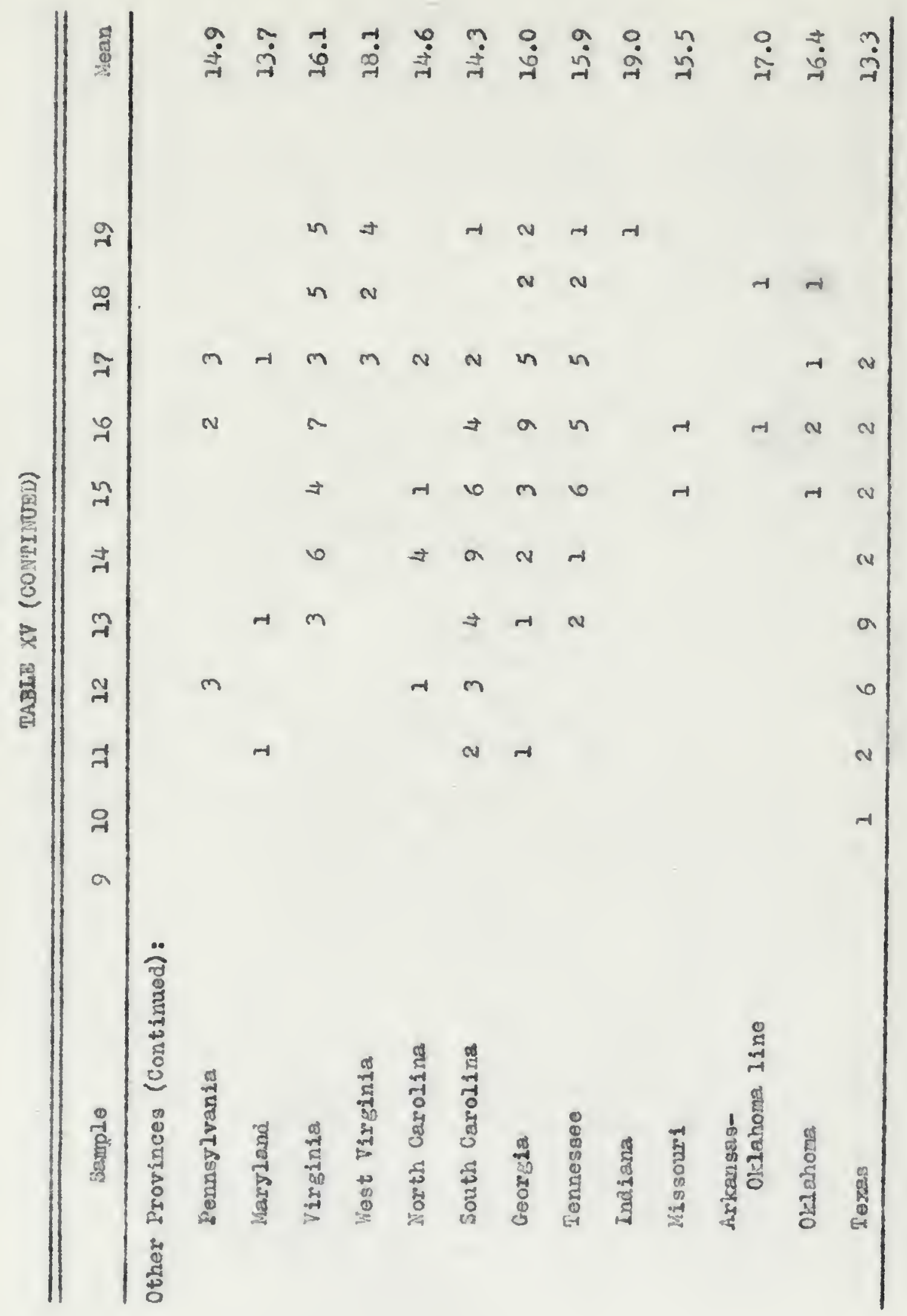




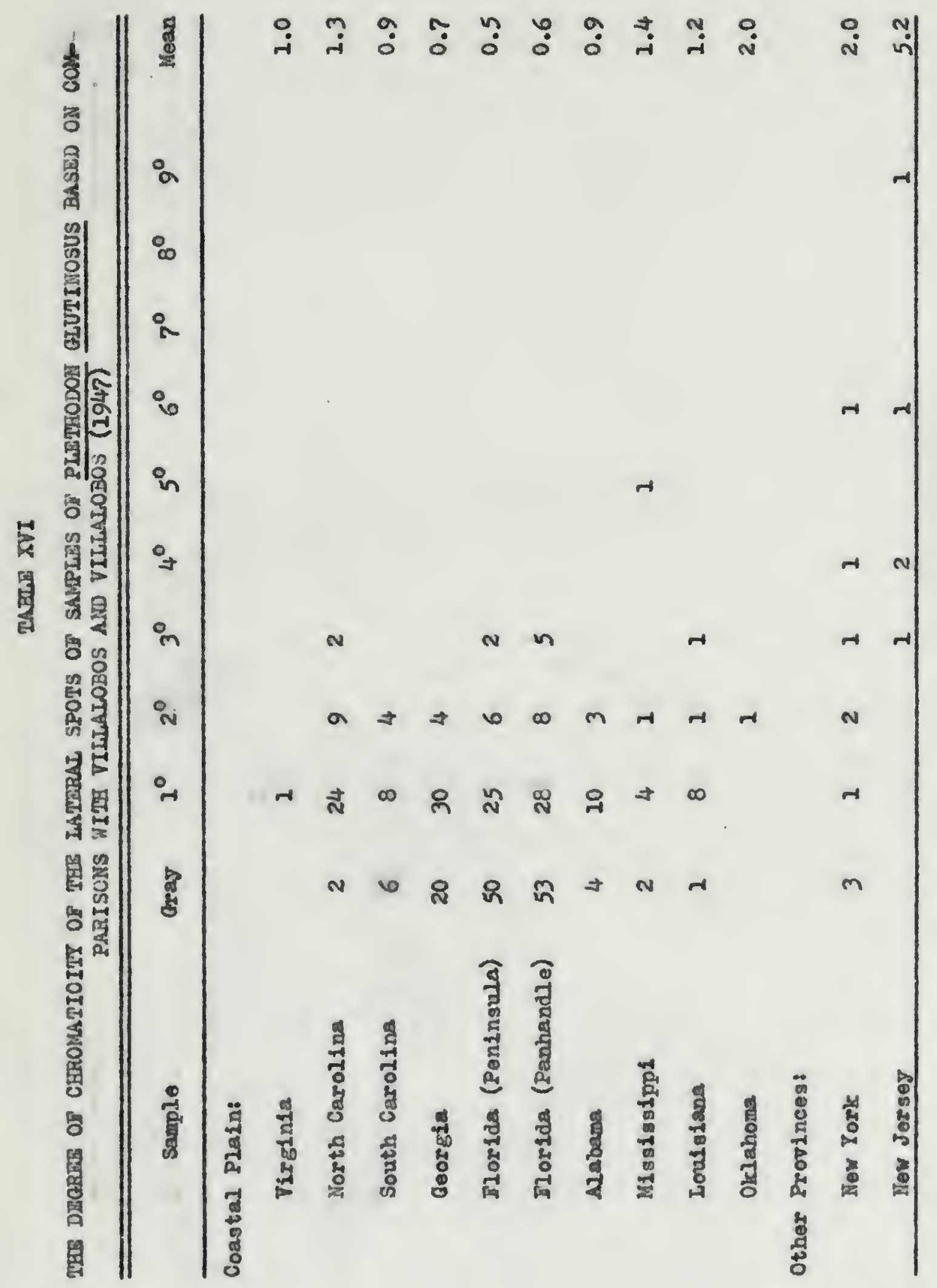




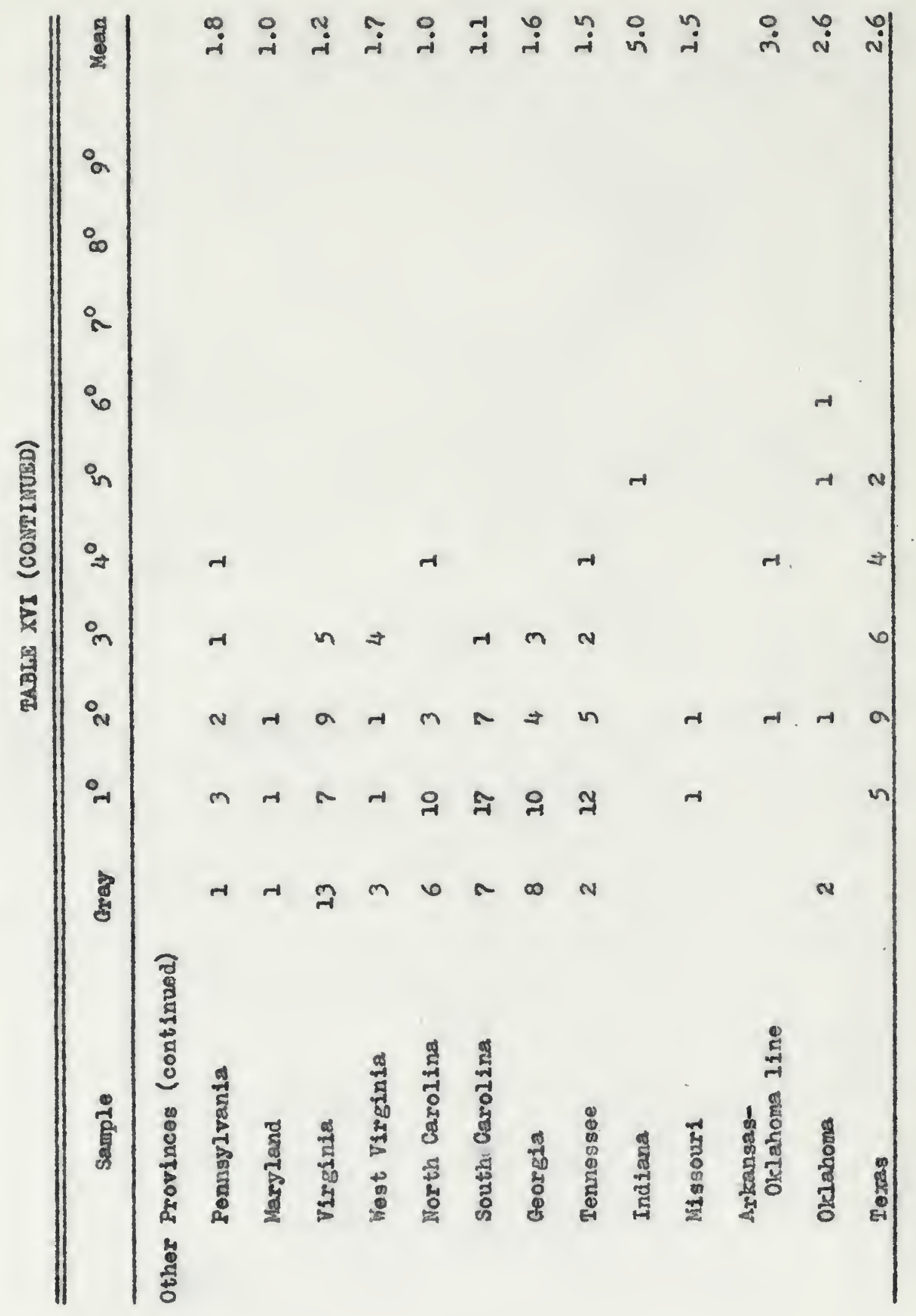


Villalobos and Villalobos' Color Atlas indicate that a large proportion of Florida specimons lack color and appear gray, while a majority of North Carolina Coastal Plain specimens, as well as those from Texas, are found in the yellow to orango range. In most other samples there is a large arount of variation in the color of the lateral spots. There is slight variation in the IIghtness of the spots, but wide overlap between most samples. The amount of chromaticity appears to be quite variable, with the Florida and Virinta samples raving an especially large proportion of gray individuals. Although there may be significant biological differencesbetween these samples in the various aspects of the lateral guanophore pigmentation, there certainly would seem to be no justification in naming either the North Carolina Coastal plain or the Florida and Georgia Coastal Plain populations as recognizable subspectes on the basis of this character.

Studies of the lateral pigment with the aid of a dissecting microscope indicate that the yellow pigmentation is not to the presence of brassy guanophores, but rather due to an actual difference in the color of the non-iridescent guanophores that appear to be the same type as those found on the dorsum, where they are always white. In classifying the color of the lateral spots, three categories were used, white, intermediate (yellowish-white), and yellow. The data on this charncter are tabulated in table XVII. In the Atlantic Coastal P1ain there appears to be an internal cline in the amount of yellow pigment, wth a reduction in intensity from North Carolina to Florida. The Teras sample has lateral pigment that is extremely yellow, but the average condition of specimens in the remainder of the range is intermediate between the two extremes. A large amount of individual vnria- 
TABIS XVIT

GEOGRAPHIC VARTATION IN THE COLOR CR LATRRAL SHOTS OF PLIMUNOA GLUTIMOSUS

Sample Yhite Yollowish-white Yellow

Coastal Plain:

Virginia

1

North Carolina

1

16

South Carolina

3

12

Georgia

16

13

Florlda (Peninsula)

26

1

Florida (Fanhandle)

12

1

Alabama

Kíssissippl

2

3

1

Louisiana

1

1

Other Provinces:

New York

Now Jersey

1

2

E ennsy I vania

2

1

Haryland

3

1

liest virginia

Virginia

6

2

lyorth Gerolina

22

13

South Carolina

12

Georgia

9

4

Tennessee

20

3

fifssouri

1

Oklahoura

Texas 
tion is present in this character within adults of each population. There is also an ontogenetic change in the appearance of lateral guanophore pigment, judging from the appearance of young specimens in populations in which the normal adult spotting appears yellow. Young individuals of all amples I have exmined possess white lateral guanophores and the change to yellow occurs at an carlier age in populations in which the normal adrit condition is yellow.

Absence of guanophores:- Specimens that completely lack dorsal and lateral guanophore pigmentation are occasionally found in samples of glutinosus from various parts of its rango. In at least two areas, this characteristic is present in a large proportion of specimens and thus deserves special mention. Ne1ll (1948) reports that in Jasper County, South Carolina, there exists a population of $\underline{P}$. glutinosus in which $100 \%$ of the specimens are characterized by the complete absence of guanophore spotting. In adjacent areas, individuals in which guanophore pigmentation was absent were also recorded, but they occur with the nomally spotted individuals. I have examined tro series of P. glutinosus from Jasper County and in both series, numbering 16 and 7 respectively, every specimen was entirely black. Two of 12 specinens that I have exemined from a locality in Dorchester County, South Carolina, also lacked guanophores, confiming the observations of earlier workers (Cope, 1889: $U_{1}$ 2; Schmidt, 1924: 67; Ne111, 194.8) that the unspotted type also occurs in thes charleston area. Several deviations described by Neill (1948) for South Carolina Coastal Platn material are not confirmed by this study. In specimens examined by me, no consistant differences in the number of costal grooves, proportional length of tail, parasphenoid teeth, molanophore pigmentation, size, heed 
shape, or structure of the vent in males could be detected. In collecting specimens at the locality inentioned by Neill (1948), 7 miles north of Tillman, Jasper County, South Carolina, I was lizpressed by the unusual agility of the andmals in escaping the collector, as weil as the apparent delicacy of the sidn, compared with other coastal PIain glutinozus. Whether these differences are real or not, they would be difficult to measure objectively, although histological examination of the integunent of the dark forn might reveal structural differences other than the absence of white spots.

Another Coastal Plain locality in wijeh a large proportion of specirons lack guanophore spotting was discovered in Morta. On the east side of the St. iolns River in Jolusia County, about 1 mile south of Astor, therc is n population of $\mathrm{F}$. glutinosus in which about half (I4 of 30) of the specimens are cntirely black. On the rast side of the St. Johns fliver, in three nearby localities in lake County (witrin 10 miles cf fstor) only one of 107 specimens shomed a complete absence of dorsal and lateral white spotting, so common on the east side of the river. Apparently the gene or genes responsible for this condition occur with small frequency in some glutinosus populatsons, but have bo come fixed in the Jasper County, Soutl Carolina population and are present in mich greater than usual frequency in the Volusia. County, Forida population.

Grobman (1944: 281) states that "there is, apparently, a large glutinosus devold of wite marking wich ranges from the Cumberland Plateau. Localities for this form are in Bibb, Chilton, Lawrence, and st. Cla1r Counties, Alabana; Chatooga, Dade, Dekalb, Fulton, Gilmer, and Murray Counties, Georgla; Edmonson, Harlan, Laurel, Morgan, and Mitley 
Counties, Kentucky; Pontotoc and Wobster Counties, Kississippi; Avery, Buncombe, Cherokee, Graham, Haywood, Macon, Polk, Swain, and Transylvania Counties, North Carolina; and Claiborne, Cumberland, Davidson, Delalb, Fayette, Fentress, Rhea, and Sevier Counties, Tennessee." I have examined living specimens from Fulton County and the Purray-Gilmer County Iine, Georgla; Harlan County, Kentucky; Haywood, Macon, and Swain Counties, North Carolina; and Davidson and Phea Counties, Tonnessee. Every specimen that I have examined from these counties, as well as many others from other counties in the region of the supposed unspotted form, possess both dorsal and lateral guanophore spots. Appare ently the difference noted in preserved specimens is not present in life, and may merely result from the disappearance of the spots as a result of preservation.

Abundance of melanophore pigmentation on chin:- In 194h, Grobman described a Texas population of Plethodon glutinosus as a separate subspecies, $\underline{P} \cdot g \cdot$ albagula. It was diagnosed as a "race of glutinosus in which the arrangement of the black pigment to forn small compact circles has been broken dom in the gular region, thereby presenting a gross appearance of a lighter throat than that found in the typical race of glutinosus." An examination of Grobman's map of the distribution of glutinosus shows a gap of approximately 120 miles between the McLennan County and the Upsur County records of glutinosus in Texas. If this hiatus actually represents an area in which glutinosus no Ionger occurs, then the population found along the Balcones Escarpment in south-central Texas rould seom to be isoleted from its nearest relatives and differentiation might be expected. However, specinens from two localities in 
the region of the Balcones Escarpment vere tentatively referred by Grobman to typical P. $g_{2}$. glutinosus. These are from Bell and BI anco Counties, and the latter record, based on only one specimen (Cli 6129), is only about 20 miles from localities at which paratypic albagula vere collected.

Brovm (1950: 32) assigned specimens from Bell, Bexar, Blanco, Comal, Hays, Kendall, Treal, and Travis Counties to $\mathrm{P} \cdot \mathrm{g}$. albagula, although Grobman had indicated that specimens from two of these counties had dark chins. Brown aleo remarked that "the status of Flethodon glutinosus albagula as a valid subspecies needs further invostigation. white throated forns have been reported from other areas supposediy in the range of $\underline{P} \cdot \underline{g}$. glutinosus."

Several series of recently collected specimens from Texas, have confirmed the fact that both lightm and dark-chinned forms occur In the region described as being inhabited by albagula. A series of 24 specimens (JS1 667-676, UF 8085 (4), 8342 (4), 8343 (6)) from a sink hole about 5 miles southwest of Austin, Travis County, are typical of Grobman's description of albagula. They possess very light chins and in life, had an abundance of yellow lateral pigment, which, except in very young specimens, fomed a continuous lateral band of guanophore pigment. This condition was mentioned by Grobman (19/4: 284) as an additional characteristic of albagula, although he pointed out that this type of pigmentation was not entirely limited to albagula. The color of this lateral band in life is unlike that of glutinosus from other parts of its range. Grobman also mentioned that the dorsum of albagula is almost devoid of white pigment spots. The living specimens 
did not lack dorsal white spots, but the spots were very small in relation to the size of the animal corpared to most glutinosus. In addition to these characters, these specimens of albagula were found to differ from glutinosus in that a rather high proportion possoss 18 trunk vertebrae. The vertebrae of one shell specinen could not be counted accurately, but of the ramaining 23, sevan have 18 trmk ver tebre, four have $17 / 18$ (the 18 th trunk vertebra bears the sacral rib on one side, the 19th on the other side), and 12 possess 17 tmunk vertebrae. Two freshly preserved specimens (UF 8009) from the Guadalupe River bluff, 2 ailes south of Sattier, Comal County, are identical in appearance with the above series. Both possass 17 trunk vertebrae.

Avallable freshly preserved specimens from two other localities, UF 7143 (3), 7145 (1), from the head springs of 4111 Creek, 5 miles northeast of Panderpool, Bandera County, and UF 3413 (6) from Bull Creek, west of Austin, Travis County, are strikingly different from albagula. The sides of these specinons, although preserved for a shorter period than many of tho albagula, possess only as Ien small scattered white spots. In none of those specimens was thore any tendency toward a coalcscence of the latoral spots into a band. The chins of most of these specimens are as dark as thoir bollies. In only three young individuals are they slightiy lighter than the bellies, but in nono are the chins as light as in albagula of comparable size.

Dr. Grobman has kindly examined the speclmens mentioned and has inforned me that the serles on which he based the description of albagula wero similar to tho specimens that were collected at the sink hole, about 5 miles southwest of Austin. The dark-chinned samples obviously do not fit the description of albagula and are thus similar 
to the specimens ho examined from Bell and Blanco Counties.

Additional material from Texas, not examined by Grobman (1944), was borrowed from Bryce C. Brown, Ottys Sanders, and the Strecker thr seum. Lost of the Strecker Luseum's collection is so faded and stained due to many years of poor preservation, that it is impossible to allo cate some specinens to either form. A series of 15 specinens (SM 16, 247-57, 1002, 1055) from Helotes, Bexar County, cannot be detemined, although at least 11 have 17 trunk vertebrae. Two others probably have 17, while the other two are too small to make accurate counts from the radiographs.

One specimen (Su 5087) from Austin, Travis County, appears to have reduced melanophore pigmentation on the chin (although its chin now appears dark due to staining).

Su 5213-16 and 5223, from Frio Canyon, Real County, may definftely be assigned to the dark-chinned form. They are presumably the specirens on which Strecker (1935: 32) based his Real County record, that Grobman (1944: fig. 3) included as a possible albagula locality on the distribution map. They are not albagula, but the dark-chinned form. Three have 17 trunk vertebrae, the other two probably also have 17 trunk vertebrae.

A large series of 4,0 specimens from San harcos, Hays County (SM 1837, 3241-2, 3244-76, 4963-7) are in poor condition. 27 have 17 trunk vertebrae, 8 probably also possess 17 trunk vertebre, and the vertebrae in the remaining specinens could not be counted. The melanophores on the chins of some of the specimens could not be discerned, but in most they appear to be much reduced as in albagula. One specimen 
(Su 32h4), however, possesses as dense a melenophore network on the chin as on the belly. In most of the larger specinens of this series, it appears that white pigment was abundant on the sides, as in albagula. Four other specimens from San varcos (OS 613, BCB 115, 2087, and 2423) also have light chins and 17 trunk vertebrae. Although all of the San larcos specimens for which accurate counts are available possess 17 trunk vertebrae, on the basis of their light chins they appear to bo referable to albagula. Grobman (194h: 283) designated 31 spectuens from San Marcos as paratypes of albagula.

Three specimens (BCB 126-8) frorn Deep Eddy, west of hustin, Travis County, have dark chins and two (117-8) have 17 trunk vertolrae. BCB 5269-73 were taken from a cave near McNeil, Travis County. All five have dark chins and two have 18 trunk vertebrae, the other three 17.

Ten specimens (SH 3162-3, BCB 7015-22) from Fern Bank, near Wimberly, Hays County, have light chins of the albagula type. Two have 18 vertebrae, the other eight 27. The presence of 18 vertebrae in only two other series from Texas, one of which is not elbagula, vould seem to indicate that the high proportion of 18 trunk vertebrae in the one sample collected 5 miles southwest of Austin, is either of local occurrence or the result of random sampling error and not of taxonomlc slgnificance. Three specinans (CHil 37666-8) from ilmberly were designated as paratypes of albagula.

A series of 16 specimens from the vicinity of another paratypic locallty of albagula (BCB 3431-40, woods near Spring Creek, 11 miles northeast of Boeme, and BCB 4983-8, from Schneider Cave, I4 
miles northeast of Boerne, hendall County) are unusual in having a large amount of ventral guanophore spotting. All but three have light chine of the albagula type, and all (except 4987, that is too small to obtain an accurate vertebral count) possess 17 trmank vertebrae.

BCB 223h, near Cibolo Creek, 18 miles northeast of Sam Antonio, Bexar County, in the vicinity of the type locality of albagula, has 17 trunk vertebrae and a light chin. It also has a large number of lateral spots, but it is a young individual and the spots have not yet coalesced to form a band.

Several other specimens from the vicinity of Austin, Travis County (BCB 301, 1161-2, Zilker Park, Austin; BCB 799, Lake Austin; ECB 1163-70, 1956-7, Austin Caverns, west of Austin; BCB 1277-78, Barton Creek, south of Austin; and vT 3414 (10), 3460 (1), junction of Barton and Little Barton Creeks), include specimens with both light and dark chins, AII except BCB 2163, 1166-8, and 1277-8 which could not be accurately counted, possess 17 trunk vertebrae.

It is difficult to analyze the distribution of the two forms, if indeed, there actually are two forms represented, because of the incomplete data on the characteristics of many of the specimens examined. Based on the freshly preserved University of Florida material, it would seem that wo are dealing with two different forms, as different from each other as nost species of Eastern Largo Plethodons. The lateral band of albagula is very similar to the type found in the yonahlossoe group. The light chin, a chameteristic of the yonahlossee group, is also found in albagula. On the other hand, some Texas populations seem to have both Iight- and dark-chinned specimens represented. I 
have not examined living specimens of the Texas dark-chinned forn, although the presorved specimens appar to be very similar to $\$$. glutinosus. Iiving albagula are very distinct from P. E. glutinosus, and It may be that albagula is a valid form, possibly a distinct species more closely related to the yonahlossee group than to the glutinosus group, or else intermediate betwoen the two groups. This rould not wile out entirely a subspeciflc relationship with glutinosus, if intergradation could be demonstrated.

Another possible interpretation is that there may be some environmental influence that is acting on certain Texas populations of glutirosus (1.e. albagula), causing then to differ phenotypically from other populations of this specles. If this were the case, then most systomatists would recognize albagula as an ecotype, not to be given nominal recognition. Grobman (1944: 284) points out that most of the avallable habitat labels accompanying specimens of albagula mention caves. More recent collections seem to indicate, however, that both types may be found oither in or out of crves. Constant temperature conditlons in caves nght plav an important part in producing a different type of yigmentation than that found in animals that undergo their embryonic development outside or caves. Plethodon glutinosus ts knom to lay its eggs both in and out of caves. Grobman (1944: 202) discrisses the possible importence of temporature during embryonic development in the production of lateral plgmentation. Temperature might also have an effect on the number of sonites (and vertebrae) In this species.

The Ealccnes Escarpment separates two major physiographic provinces, the Coastal Plain and the Edward's Plateau section of the 
Great plains. The change in the underljing rocks, vegetation, and rainfall at the Belconee liscarpment is very abrupt (Smith and Buechner, 1947). No correlation is indicated on the basis of the present distributional data, however, since both lightm and derk-chinned specimens have been collected on both sides of the Belcones Escarpment (figure 23).

A third possitile explanation of the situation, the one reflected by the current nomenclature, is that the two forns are subspecifically related. The puzzling samples frow iravis County, in which both light- and dark-chinned specinens, as well as intermeriate types appear in one population, could be considered evidence for intergradation between typical E. E. GIutinosus and $\underline{P} \cdot g \cdot$ albasula. According to this interpretation, the specimens from Bell, Blanco, Landera, and Real Counties might he assigned to P. E. Glutinosus, occurring, as therg do, to the north and west of the albagula records. Lost of the specimens from Hays, Comal, liendall, and Bexar Counties show the characteristics of albagula, wile both typical albagula, typical Elutinosus, and internediates occur in Travis County. Geographic replacement between the two forms is a definite possibility. If the true relationship is found to be subspecific, it may be postulated that the isola tion in which albaguls differentiated was of consicierable duration and that typical glutinosus has only recently reinvaded the region, with only a slight amount of secondary intergradation.

A field study of the species in the area involved is much needed. A comparison of living specimens from the entire region, a study of the life history, ecological requirenents, and more infomation on the distribution of the animals will be needed before the proper 
systematic status of the Iexas Large Methocions can be deternined. With our present lnowledge, it would seer best to propose no change in the exsting nomenulature with regard to albagula, pending a study that would clarify its true status.

Wright and Wright'(1938: 34) report P. glutinosus froin Kedina County, Texes, but no specimens seem to be available now fron this county. Strecker (1902: $100 ; 1908: 80)$ reports the species fror lic Lennan County on the basis of two specimens, one a sight record. Its actual occurrence in this county certainly needs confirmation. If $\underline{P}$. glutinosus does not occur in iclennan County, then the gap in tise range of Texas glutinosus is greater than indicated above.

Strecker (1915: 55) states that he collected two specimens near Cleveland, Liberty County, in the southeastem Coastal Plain of Texas. Since no other records of $P$. glutinosus are knom for over 250 miles from this locelity in any direction, this record should be deleted from the authenticated range of $\underline{P}$. glutinosus until it can be verified.

Surmary of geograohic variation in Plethocion glutinosus:- In most of the characters stucied, geographic variation was found to be present. These characters were not chosen at rendon, however. Thøy were selected for detailed analyg1s because previous workers had found evidence of geographic variation in then and this had been supnorted by preliminary observations made by the writer. In a critical study of other characters of Ilving specimens from various parts of the range, I could find no others that could be successfully correlatod wh geography.

In the number of trunk segments, the differences between 


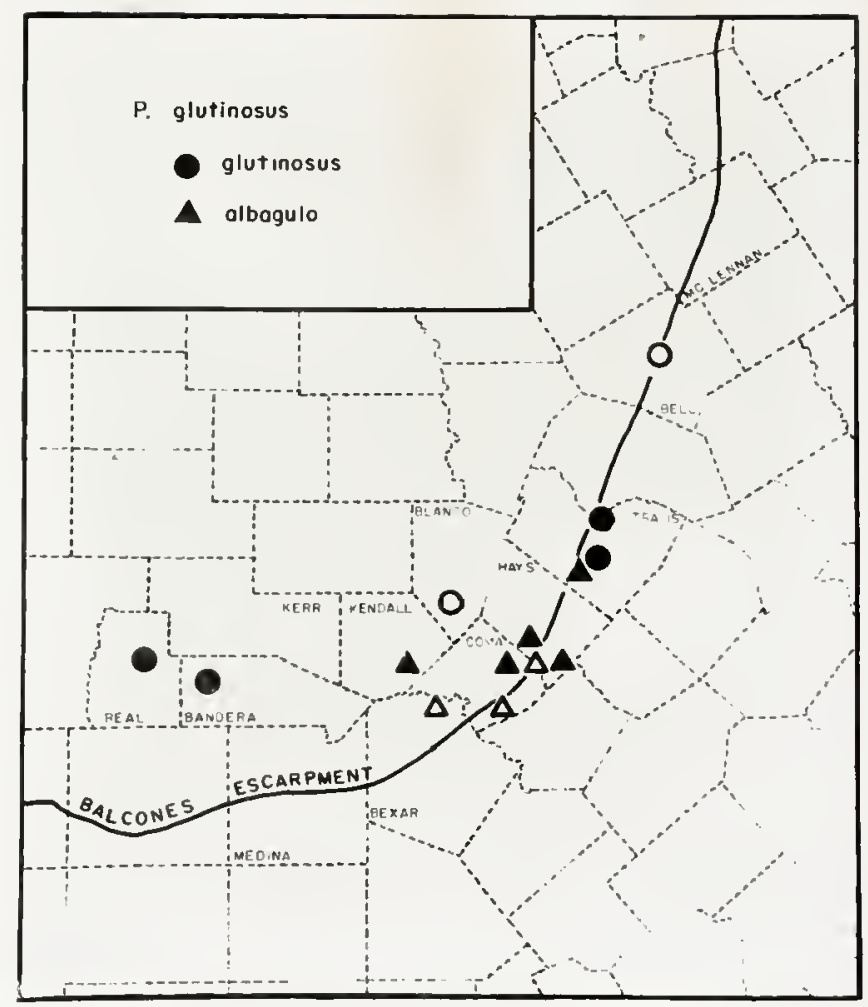

Fignure 23. The distribution of the dark-chinned (Elutinosus) and Ilght-chinnod (albarula) populations of P. glutinosus in central Texas. Solld symbols represent localitics from which specinens have been examined by the writer. Hollow symbols represent Iiterature records of Grobman (194/4). 
Ceocraphic samples are very slight, but, in the other characters studied, consistent differences between some samples are demonstrable. Southeastern Coastal Plain specimens are signiflcantly smaller than most other ?. glutinosus. The number of vomerine toeth is reduced in Florida glutinosus, compared rith the Virginfa mountain sample, and the North Carolina and Virginia Coastal Flain syecinens oxhibit a further reduction. The size of the dorgal spots shows clinal veriation in the Atlantic coastal Plain, incraesing from north to south. The spot size of other populations, excopt those in the Blue Fidge Frov ince of North Carolina, and in Texas, appears to be avout the same as southern Coastal rlain animals. The color of the dorsal spots is extrenely variable, but unfformy wite in the southern Plednont and Blue Ridge Provinces north of Ceorgia, and uniforily brassy in the Gulf Coustal Plain from $k$ fssissippi to Florida. Lateral spots are larger and mors yellow in color in the Atlantic Coastal Plain and in Teris. Texas animals usually possess a great reduction in the number of melanophores on the chin.

On the basis of the above data, several tentative conclusicns on raciation in $P$. Glutinosus may be suggested. The Texas populations are apparently isolated from the remainder of the species. Ifving Texas spectmens that have been examined differ in several ways fron clutinosus in other parts of its range and are the most distinotive of all of the samples of this species studied by the writer. For the present, it would seem advisable to continue to recognize albagula as a separate form, although there remain many questions that, muat be answered before its correct systematic position can be deternined. 
Another population that differs from most other 2 . Blutinosus in a number of ways is tho one that occurs in the South Carolina, North Carolina, and rirginia Coustal Plain. Its reduced vomerine teeth, small dorsal. spots, lateral yellow band of guanophore snots, and small size serve to distinguish a large proportion of these animals from the re mainder of the species. Ho single one of these characters is limited to this popvlation, however, and all but the last appear to be the result of a gradual clinal-twpe change from south to north in the Coastal Plain, with wide overlap between adjacent populations. Most systematists rould not recognizo the and products of such a cline as senarate subspecies. For those that care to recognize the northern end of this cline as a nominal form, the namo cylindracea is available for the South Carolina population. P. E. chIorobryonis Mittlenan, based on spec:mens from the forch Carolina Coastal Plain would not appear to be valid, since there is wide morphological overlap between the North Carolina and South Carolina populations.

Sinilarly, for those who would recognize the southern end of this sline as a separate subspecles, the name grubmani would not be applicable, ninco it is preoccupled by at least two earlier nanes, vamlolata being the oldest. This name would be avallable for all Coastal Plain P. glutinosus if, in the future, it is shom that these populations should be given racial recognition. At present, there are no Inom characters, other than size, that would support this thesis. Athough, as jat, there is not sufficient reason to recognize a southecstern Coastal Plain race (or races), the informition on geographic variation of several characters is extremely suggestive in expleining 
some of the distributional problems and relationships of these populations of Plethodon glutinosus.

The Florlda and Georgia samples are closer to the nonCoastal Plain samples than are the Dirginia and Carolina Coastal Plain populations in every character except madimum aize. If the wideranging $\underline{P}$. glutinosus was first able to adapt itself to the Coastal Plain environment in Georgia (or, perhaps to the west of Georgia), it probably migrated to the northeast into the coastal areas of the Carolinas and southeastern Virginia. There are no records of glutinosus from the Coastal Plain of northern Virginia, the Del-Mar-Va Peninsula, southern New Jersey (south of Ocean County), or Long Island, al though Plothodon cinereus has boen able to adapt to Coastal Flain conditions in all these areas. It wolld therefore appear that northeastern Piedmont glutinosus have been unable to move into the Coastal Plain. The fact that Virginia Coastal Plain glutinoaus are so different from upland Virginia glutinosus lends support to the theory of a more southerly origin of the former, rather than a close relationship to glutinosus populations in the adjacent Piedmont.

One other interesting situation has been discovered as a result of field work being done in eoutheastern Tennessee by Hr. Richard H. Johnson. Nicholls (1950: 312) has suggested that there is more than one type of Plethodon glutinosus in eastern Tennessee, but does not describe them. Field work in western North Carolina has indicated that glutinosus of that rogion are unusual in invariably possessing white dorsal spots. Nr. Johnson has also collected this white-spotted glutinosus at soveral localities in eastern Tennessee. 
In other localities, however, eastem Tonnessee glutinosus populations exist in which the amount of brassy fleching is greater than in most Florida specinens. (This type of brassy flecked Elutinosus also occurs in northem Georgia at Potato Patch Mountain, Gilmer county line). It is quite possible that more than one form is represented in this area and it is hoped that $3 r$. Johnson's fleld studies will clarify the altitudinal, ecologicol, and geographic distribution of the two forms, as well as to shed some light on their relationships.

\section{Plethodon glutinosus glutinosus (Green)}

Salamandra glutinosa Green (1818: 357). (Type locality probably

Princeton, New Jersey)

Salamandra variolata Gilliams (1818: 460). (Type locality, Southem

States, probably Florida)

Salamandra cylindracea Harlan (1825: 156). (Type locality, South Carolina, probably the vicinity of Canden)

Plethodon glutinosus (Green). Tschudi (1838:58). Bishop (1941: 219-32). Plethodon glutinosum (Green). Gray (1850: 39).

Salamandra albopunctata Valenciemes in Dumeril and Bibron (1854: 81). (Type locality, Savannah, Georgla)

Plethodon variolosum (Gilliams). Dumeril and Bibron (1854: 83). Salamandra elongata Valenciennes in Dumeril and Bibron (1854: 64) (Type locality not designated)

Salamandra melanoleuca Vied (1865: 130). (Type locality, Nazareth, Pennsylvania)

Plethodon glutinosus glutinosus (Green). Dunn (1920: 131). Bishop (1943: 250-3). Grobman (1944: $278-83$ ). 
Plethodon glutinosus grobmani Allen and Neill (1949: 112). (Type locality, noar Silver Springs, larion County, Florida)

Plethodon kentucki lyttlenan (1951: 105-8). (Typo locality, Big Black Mountain, Harlan County, Kentucky)

Plethodan glutinosus chlorobmonis llittleman (1951: 108). (Type locality, 13 miles north of New Bern, Craven County, North Carolina)

Plethodon jordani kentucki wittlenan. Schmidt (1953: 37).

Type:- Dunn (1926: 138) states that the type is not knom to exist, but that the type locality is obvlously Princeton, New Jersey.

Diagnosis:- A dark-bellied, dark-chInned Bastern Large Plethodon with dorsal and lateral guanophore spots, and without red pigment.

Range:- Central New York west to central and southern Illinols, south throughout all the states east of the lississippl liver, except for southern Florida, and the Atlantic Coastal Plain north of southern Virginia. West of the Mississippi River, it occurs in east-central and southern Missouri, the northwestem half of Arikansas, eastern Oklahoma, and extrexe northesstem Texas (figure 2h). Dark-chinned specimens which inay be referable to this subspecies are also knom from Real, Bandera, Blanco, Travis, and Boll Countios in the region of the Balcones Fiscarpment of Texas (flgure 23).

Description:- This forn is extrenely vartable and the reader is referred to the above discussion of geographic variation in this species for descriptions. The costal grooves usually number 16, the trunk vertebrae 17. Vomerine teeth range from 4 to 17 in a series. 


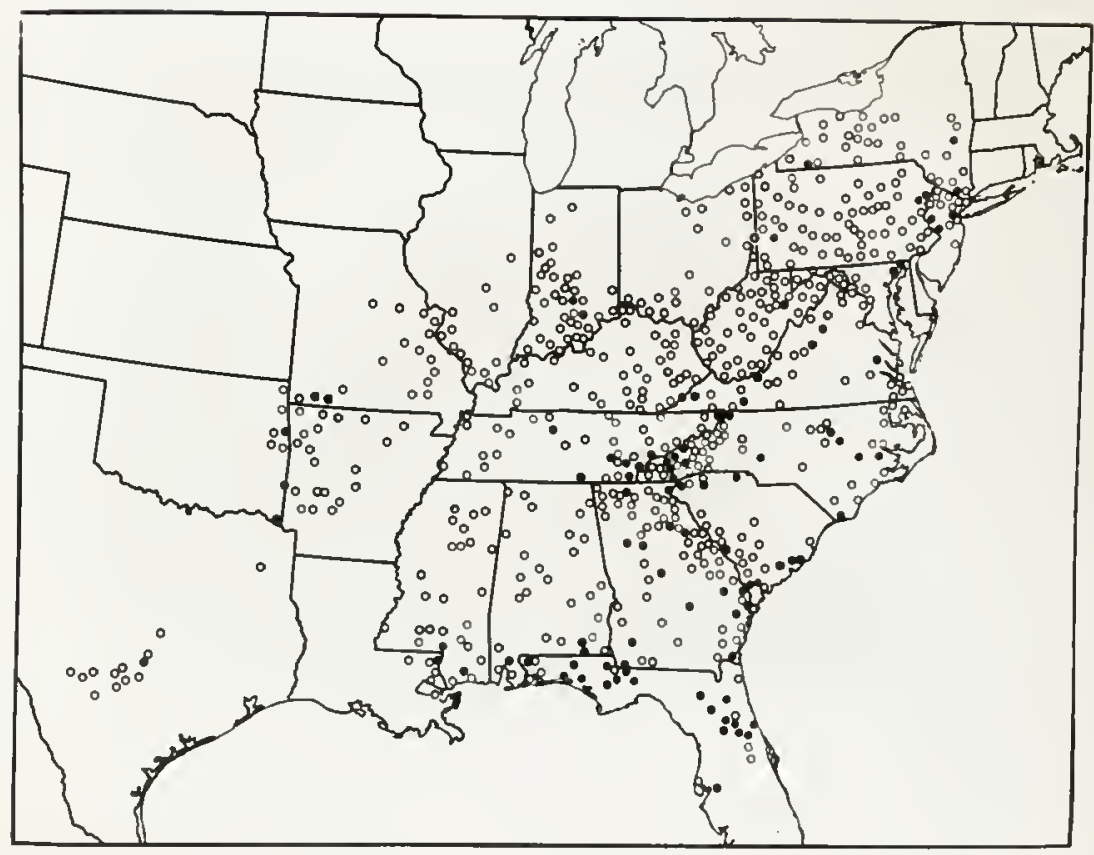

Figure 2h. The distribution of Plethodon glutinosus in eastern united States. Solid symbols represent localities from which living specimens have been examined. Hollow symbols represent literature records and localities from which preserved specimens have been examined. See figure 23 for a map of the distribution of the subspecies of $\underline{P}$. glutinosus in Texas. 
There is geographic variation in size, the largest peninsula Florida specimen (from Eureka, Narion County), is $69 \mathrm{~mm}$. In snout-vent length, while the largest specimen on record (orton, 1946) is 88 m. in snoutvent length. Sexual maturity is reached between 40 and $56 \mathrm{~mm}$. In snout-vent length in Florida, but there is little or no infomation for other areas.

\section{Plethodon plutinosus albagula Grobman}

Plethodon glutinosus albagula Grobman (1944: 283). Brown (1950: 32-3).

Inpe:- CM 9652, an adult male, collected 20 miles north of San Antonio, Bexar County, Texas, on February 24, 1935, by Wesley Clanton.

DLagnosis:- A subspecies of Plethodon glutinosus that differs from the typical race in possessing a recuction of melanophore pigmentation on the chin.

Range:- Known from Bexar, Kendall, Comal, flays, and Travis Counties, Texas.

Description:- Living specimens from a sink hole, about 5 riles southwest of Austin, Travis County, Texas, besides possessing the diagnostic light chin, also have exceptionally yellow lateral spots, wich are often so large that adjacent spots fuse to form a lateral band in adults. The dorsal spots are small and whito. As noted above, this population is unusual in the number of trunk vertebrae, so it may not be typical in other respects.

The costal grooves usually number 16, the trunk vertebrae 17. Vomerine teeth range from 4 to 11 in a serles. This form is large in 
size, the largest specimen examined is $75 \mathrm{~mm}$. In snout-vent length.

\section{SURAMPY}

A systematic study of the North Mmerican salanander genus Plethodon indicates that there are three major groups in the genus. These are called the Vestem Plethodons, the Eastem Small Plethodons, and the Iastern Large Plethodons. Special emphasis has been placed on a study of pigmentation characters in Iiving specimens and in the variation in trunk vertebrae measured by means of X-ray photographs. A method of correlating the number of costal grooves with the number of trunk vertebrae has been suggested.

The Vestern Plethodons are divided Into four species groups. The Plethodon vandykei Group, with one species, vandykei, includes three subspocies. The Plethodon vehiculum Group includes two mono typic species, dunni and vohiculum. The third species group includes a single species, formerly knom as $\underline{P}$. elongatus, for which a new name is proposed, $\underline{P}$. productus. The fourth species group of western

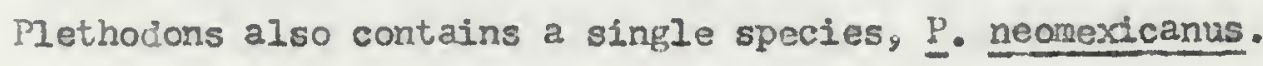

The Pastem Small Flethodons are divided Into two species groups, the Plethodon weller1 Group and the Plethodon cinereus Group. The first includes two species, welleri and richmondi (with three races). The Plethodon cinereus Group consists of two species, dorsalis with two subspecies, and cinereus with three races.

The Castern Large Plethodons are divided into three species groups. The P. wehrlei Group includes one species, wehrlei, with three 
races. The Plethodon yonahlossee Group includes three species, yonahlossee, ouechitae; and caddoensis. The Plethodon glutinosus Group has two species, jordani with eight subspectes (one, unfcoi, is new), and glutinosus with two races.

The Eastern. Large Plethodons and the Eastern Small Plethodons are more closely related to each other than either is to the Festern Plethodons. The Fastern Small Plethodons appear to be closer to the Western Plethodons than are the Eastern Large Plethodons.

\section{LITERLATURE CITED}

Allen, E. Ross, and Wilfred T. Nelll

1949. A new subspecies of salamander (genus Flethodon) from Florida and Georgia. Herpetologica, 5 (?): II?-II4.

Balley, Joseph R.

1937. Notes on plethodont salamanders of the southeastern United States. Oce. Papers ins. Zool., Univ. Mich., (364): $1-10$.

Batrd, S. F.

1850. Revision of the North American tailed-Batrachia, with descriptions of the ner genera and species. Jour. Acad. Nat. Se1. Inila., 2nd ser., I (L): 281-292.

Barbour, Roger w.

1953. The amphibians of Big Black hountain, Marlan County, Kentucky. Copcla (2): 84-89.

Bishop, Sherman C.

1924. Notes on salamanders. Bull. N. Y. State ins., (2.53):

87-102, pls. 1-3.

1927. The amphibians and reptiles of Allegany State Park. N. Y. State thus. Landbook (3): 3-14l, figs. 1-58, map.

1928. Notes on some amphibians and reptiles from the southeastern states with a description of a new salamander from North Carolina. Jour. Hilsha 14tchell Sc1. Soc., $43(3-4)$ : 153-170, pls. 23-26.

1934. Deseription of a ner salamander from Oregon, vith notes on related species. Proc. B10l. Soc. Wash., 47: 169171,1 pl: 
Eishop, Sherman C. The salamanders of Ner York. Erull. N. Y. State 角us., (324): 1-365, figs. 1-66.

19lilb. Notes on salamanders with descriptions of several new forms. Occ. Papers Mus. Zool., Undv. 1 Hich., (45I): 1-25, pls. 1-2.

19l43. Handbook of salamanders. Ithaca. Comstock Pub. Co.: i-xiv, 1-555, pl. I, figs. 1-14h, maps 1-56.

Blanchard, Frank $N$.

1926. A collection of amphibians and reptiles from southern Indiana and adjacent Kentuck. Papers Mich. Acad. Sci.,

Arts and Letters, 5: 367-388, pls. 22-23.

Blatchley, w. S.

1901. On a small collection of batrachians from Temessee, With descriptions of two new species. 25 th Ann. Rept. Dept. Geol. indiena, 1900: 759-763.

Bogert, Charles 11.

1952. Relative abundance, habitats, and nomal thermal levels of some Virginian salananders. Ecology, 33 (I): 16-30, figs. 1-6.

Eonaparte, C. I.

1839. Lcon. Fauna Italica, 2(26): no pagination. Rome.

Boulenger, G. A. Catalogue of the Batrachia Gradientia S. Caudata and Patrachia Apoda in the collection of the British Museum, 2nd Ed.: i-viii, 1-127, pls. 1-9.

Bragg, Arthur N .

1952. Amphibians of VcCurtain County, Oklahoma. Waszann Jour. Biol., $10(2): 241-250$.

1955. The Amphibia of Cherokee County, Oklahona. Herpetologica, II (1): 25-30.

Bragg, Arthur N., and W. F. Hudson 1951. New county records of Salientia and a surmary of the known distribution of salamanders in Oklahoma. Great Basin Nat., 11: 87-90.

Breder, C. H., Jr., and R. B. Breder. 1923. A list of fishes, amphibians, and reptiles collected in Ashe County, North Carolina. Zoologica, 4 (1): 1-23, Iigs. 1-8. 
Brimley, C. S.

1912. Notes on the salamanders of the North Carolina mountains with descriptions of two new forns. Proc. B10l. Soc. Viash., 25: 135-140, pls. 6-7.

1926. Revised key and list of tho amphiblans and reptiles of North Carolina. Jour. Elisha Mitchell Sci. Soc., 428 $75-93$.

1927a. Some records of amphibians and reptiles from North Carolina. Copeia (162: 10-12).

1927b. An apparently new salamander (Plethodon clemsonae) from S. C. Copeia (164): 73-75.

1928. Yellow-cheeked Desmognathus from Hacon County, N. C. Copeia (166): 2l-23.

1940. The amphibians and reptiles of North Carolina. Carolina Tips, 2 (2): 6-7.

Brooks, Laurice

1945. Notes on amphibians Irom Bickle's knob, Wost Virginia. Copeia (4): 231 .

1948. Notes on the Cheat Mountain Salamander. Copoia (4): 239-244, f1g. 1 .

Brown, Bryce C.

1950. An annotated check list of the reptiles and arphibians

of Texas. Baylor Univ. Studies, 1-xil, 1-258.

Brow, W. C., and J.R. Slater

1939. The amphibians and reptiles of the 1slands of the state of Nashington. Occ. Papers Dept. Bol., Collese of Pupet sound, (4): 6-13.

Burns, Douglas $\mathrm{M}$.

1954. A new subspocies of the salamander plethodon vandyke1. Herpetologica, $10(2): 83-87$.

Chadrick, Claude S.

1940. Some notes on the burrows of Plethocion metcalfi. Cope1a (1): 50 .

Chamberlain, $\mathrm{B}$.

1928. Some salananders fron Caesar's Head, South Carolina. Copela (167): 51-52.

Chermock, Falph L.

1952. A key to the amphibians and reptiles of Alabana. Geol. Surv. Alabana, Mus. Paper (33): 1-88, figs. 1-10. 
Clay, Mlliam M., Roberta Burckhardt Case, and Robert Cunningham 1955. On the taxonomic status of the sling salamander, Ilethodon glutinosus (Green), in southeasterm Kentucky. Trans. Kentucky Acad. Sci., 16 (3): 57-65, figs. 1-2.

Coker, w. C.

1939. upportunities for biological work at lighlands and report of progress. Highlands lius, and Biol. Lab. Pub. (4): $1-16$, fing. 1 .

Cooper, J. G.

1860. No. 4 report upon the reptiles collected on the survey. Rept. Expl. and Surv. from Miss. River to Pacific acean, 12 (2): 292-306, ,1. 31, fig. 4 .

Cope, E. D.

1867. A review of the species of the Ambystoridae. Proc. Acad. Nat. Sci. Phila., 19: 166-211.

1869. A review of the species of the Plethodontidice and Desmognathidae. Proc. Acad. Nat, Sci., Phila., 21: 93-118.

1883. Notes on the geopraphic distribution of Batrachia and Reptilia in westem North America. Froc. Acad. Nat. Sci., Phila., 35: 10-35.

1889. The Batrachia of North America. Bull. U. S. Nat. Mus., (34): 3-525, pls. I-79, 83, 86, figs. 1-119.

Cowan, I. M.

1937. A review of the reptiles and armpibians of British Columbia. Rept. Prov. Shs. Nat. Hist. for 1936: 16-25.

Cox, Philip

1907. Ifzards and salamanders of Canada. Proc. Miramicht Nat. Hist. Assn., (5): 46-55.

Davis, Nathan Smith, jr., and Frank L. Rice.

1883. Descriptive catalogue of Worth inerican Iatrachia and Reptilia found east of the Mississippi River. III. Stat, Lab. Nat, hist. Bull., 5: 1-67.

Deevey, E. S., Ir.

1949. Biogeography of the Pleistocene. Part I. Europe and Worth Americe. Bull. Geol. Scc. Amer., 60: 1315-14l6, figs. $1-27$.

Duellman, Williarn $\mathrm{E}$.

1054. The salarander Plethodon richmondi in southwestern

onio. Copeia (1) : 40-55, 118.1 .

Dumas, Philip C.

1955. Eggs of the salamander Plethodon dunni in nature. Copeia (1): 65 . 
Dusoril, A. M. C., and G. Bibron

1854. Histoire Neturelle des Reptiles, 9: i-2xx, 1-440.

Dundee, Harold A.

1947. Notes on selamanders collected 1ri Oklahoma. Copeia

(2): $117-120$.

Dunn, I. P.

1917. Qptile and amphibian collections from the North Caroling mountains, wht esvecial reference to salananders. Bull. Amer. kus. Nat. Hist., 37: 593-634, pls. 57-61, figs. I-?.

1918. The colloction of Mnhibia Caudats of the museum of Comparative Zoology. Bull. Hists. Gomp. Zool., 62: 445-471.

1920. Some reptiles and amphibians from Virginia, North Carolina, Tennessee and Alabama. Froc. Eiol. Soc. Wash., 33: $129-137$.

1926. The salamanders of the family Plethodontidae. Smith College Ann. Pub.: 1-44I, pls. 1-3, maps 1-86.

Dunn, E. R., and A. A. Heinze

1933. A new salamander from the Ouachitae Hountains.

Copeia (3): 121-122, 1 fig.

Dury, Ralph, and Mlliam Gessing, Jr.

19lo. Additions to the herpotofauna of kentucky. Herpetologica, $2(2): 31-32$.

Fitch, H. S.

1936. Amphibians and reptiles of the Rogue River basin, Oregon. Amer. lid. Nat., 17 (3): 63L-652.

Fitzinger, I. J.

1843. Systema Roptilíun. Ámblyglossae. ill-vi, 1-106.

Fowler, H. K., and E. R. Turn

1917. Notes on salamenders. Proc. Acad. Nat. Sci. Fhila.,

69: 7-28, pls. 3-4.

Fowler, James A.

1951. Proliminery obscrvations on an aggregation of Plothodon

dixi. Herpotologica, 7 (3): 147-148.

Garman, Harrison

1894. A prelininary list of the vertebrate animals of Kentuck. Bull. Essex Inst., 26 (1): 1-63.

Garman, Samuel

1884. The North American reptiles and batrachians. Eull.

Essex Inst., 16: 3-46, ftgs. 1-6. 
Gillians, Jacolv

1818. Descriptions of two new species of Iinnaean Lacerta. Jour. Acad. Nat. Sci. Phila., 1: 460-461, pl. 18, fig. 1 .

Gordon, Kenneth

1939. The Amphibia and Reptilia of Uregon. Oregon State Tion., Sturties in $2001 .$, (1): 1-82, figs. 1-54.

Gordon, Robert E.

1952. A contribution to the life history and ecology of the plethodontid salamander Aneldes aeneus (Cope and Pactard). Amer. Midland Nat., 47 ( 3 T: 606-701, figs. 1-6.

Gordon, Robert E., and Richard L. Smith

1949. Notes on the life histury of the selamander Aneldes aeneus. Copeia (3): 173-175.

Graf, William, Stanley G. Jewett, Jr., and Kenneth L. Gordon 1939. Records of amphibians and reptiles from Oregon. Copeia (2): 101-10l.

Gray, I. E.

1939. An extension in the range of Plethodon yonahlossee. Copeia (2): 106.

Gray, J. I.

1850. Catalogue of the specinens of amphibians in the collection of the British huserm. 2t. 2, Batrachia Gradientia. Iondon: 1-72, pls. 3-4.

Green, Donald $\mathrm{M} .$, and Marren F. Walker, Jr.

1954. A northern extension of the range of Plethodon richmondi in Ohio. Copeia (1): 60 .

Green, Jacob

1818. Descriptions of several species of North American Amphivia, accompanied with observations. Jour. Acad. Nat. Sci. Phila., I (2): $348-358$.

Green, N. Bayard

1938. A new salamander, Plethodon nettingi, from West Virginia. Ann. Carnegie Mus., 27: 295-299.

1939. The pygmy salamander Desmognathus mighti King, on Thite Top Hountain, Virginia. Copeia (I): 49 .

Green, N. Bayard, and N. D. Richmond

1944. Courtship of Plethodon metcalfi. Copeia (4): 256.

Grinnel1, Joseph, and C. I. Canp

1917. A distributional list of the amphibians and reptiles of Califormia. Univ. Cal. Fub. 2001., 17 (10): 127-208, rigs. 1-14. 
Grobuan, Arnold i.

194h. The distribution of the salananders of the genus

Flothodun in easterm United Stalea and Canacia. Ann. U. Y. Acad. SCI., 45 (7): 261-316, 11g3. 1-11.

1949. Some recent collections of Plethodon from Virginia with a description of a new form. Proc. biol. Soc. lish., 63: $135-142$.

1950. The distribution of the races of Des:nognathus fuscus in the southern states. Nat. list. Misc., Chicago k.cad. Sc1., (70): 1-8, rigs. 1-2.

Hairston, Nelson G.

1949. The local distribution and ecology of the pisthodontid salamanders of the southem Appalachians. Ecol. Moriogr., 19: 47-73.

1950. Intergradation in Appalachian salamanders of the genus Plethodon. Copeia (4): 262-273, figs. 1-3.

1951. Interspecies competition and its probable influence upon the vertical distribution of Appelachian salamanders of the gerus Plethodon. Fcology, 32 (2): 256-274, f1ga. 1-2.

liafreton, Nelson G., and Clifford $H$. Pope

1948. Geographic varlation and spectation in Appalacisian salamanders (Plothodon fordani group). Evolution, 2(3): $266-278$.

Herdi, G. h.

1926. Araphibia of Iritish Columbia. Rept. Prov. ling. Nat. Hist. for 1925: C21-C2L.

Hiarlan, Richard

1825. Description of the Coluber fulvius, Linn., a new species of Scincus, and two new species of Salamandra. Jour. Acad. Wat. Sci. Phila., 5 (1): 154-158.

Hassler, Willian G.

1932. New locality reconds for two salamanders and a snake

in Cattaraugus County, Nerr York. Copela (2): $94-96$.

Highton, Richard

In press. The life history of the sling salarander, flethodon glutinosus, in Florida. Copela, 1956 (2).

Hightcn, Richard, and Amold b. Grobmen

In press. Two new subspectes of the Eenus Plethodon from the southeastern United States. Horpetologica, 1956. 
Hiton, 絓IIIan A.

1946. Salamanders from northem Califomia. Copoie (1): 1.5 .

1948. Salaminder notes from the northwest. Herpotologica, $4(3): 120$.

Hof man, Richard L.

1953. Flethodon wellerl Walker in Tennessee. Jour. Tenn. Acad. So1., 28 (1):86-87.

Hoffman, Richard L., and Leslie Hubricht

1954. Distributional records for two species of Plethodon in the southern Appalachians. Ferpetologica, 10 (2): 19I193.

Hoffman, Richard L., and H. I. Kleinpeter

1948a. A collection of salamanders from Mount Rogers,

Virginia. Jour. Nash. Acad. Sci., 38 (3): 106-108.

1948b. Amphibians from Burke's Garden, Virginia. Arrer. litdland Nat., 39 (3): $602-607$.

Holman, J. Alan

1955. Fall and winter food of Plethodon dorsaits ir.

Johnson County, Indiana. Copeia (2): 143.

Howe II, A. H.

1909. Notes on the summer birds of north Geortia. Lule, 26 (2): 129-137.

Howe11, Thelma

1954. Wethods of counting costal grooves in salamanders.

Jour. Tenn. Acad. Sci., 29 (I): 42-44, fig. 1.

Horell, Thelma, and Ani Hawkins

1954. Variation in topotypes of the salamandor Fiethodon

jordani melaventris. Copeia (1): $32-36$, fig. $1-2$.

Jesett, Stanley G., Jr.

1936. Notes on the amphibians of the Portland, Oregin,

area. Copeia (1): 71-72.

Kermode, Francis

1926. Accessions in Rept. Prov. Mas. Nat. Hist. for 1925: 35.

K1ng, $111 \div$ s

1939. A survey of the herpetology of Great Smoly Hountains National Park. Amer. Ifidand liat., 21 (3): 531-532, fies. $1-9,1$ nap.

Lachner, Irmest A.

19l2. An aggregation of snakes and salamanders during hibernation. Copeia (4): 262-263. 
Logier, E. B. S.

1932. Some accounts of the amhibiars and reptiles of

Eritish Colurbia. Irans. Can. Inst., 18 (2): 311-336.

Logier, B. B. s., and G. C. Toner

1955. Check-list of the amphiblans and reptiles of

Canada and Alaska. Contr. Royal ontario ius. Zool. \&

Paleon. ( 41$): 1-v, 1-88,77$ maps.

Lowe, Charles H., Jr.

1950. The systonatic status of the salamander Plethodon

hardil, wth a discussion of biogeographical probleres in

ineides. Copela (2): 92-99, fig. 1 .

1955. The salamanders of Arizona. Trans. Kansas Acad. Sc1., $58(2): 237-251$, figs. $1-5$.

Mirt, of, Bernard, and Robcrt L. Humphries

1955. Observations on some amphiulans from Georg1a. Copeia

$(3): 245-24.8$

Mayr, Ermst

1931. Notes on Halcyon chloris and sone of its subevecies.

Amer. Mus. Nov., Th69): 1-10.

Hittienan, Iyron $B$.

1948. American Caudata. V. Hotes on cortain Appalachian

salamanders of tho genus Plethodon. Jour. Wash. Acad. Sc1.,

38 (12): $416-419$.

1951. American Caudata. VI. Tro new salamanders of the

genus Plethodon. Herpetoloplca, 7 (3): 105-112.

Hohr, C. E.

1937. Notes on cave vertebrates. Proc. Penn. Acad. Sci., 11: $38-42$.

1952. The eggs of the 2ig-zag salamander, Plethodon cinereus dorsalis. The Amarican Caver: 59-60.

Uuchmore, willian B.

1955. Brassy rleching in the salanander Plethodon c. cinereus,

and the validity of lethodon huldae. CopeIa (3): I70-172.

Neill, "ilfred $\mathrm{T}$.

1948. An unusual variant of Pl-thodon glutinocus in South

Caroline. Copela (4): 247-25I, 11g. I. 
Notting, M. Graham

1936a. Wehrle's salanknder, Plethodon wehrlel Fowler and Dunn, in Mest Virginia. Prec.". Va. Acad. ici., 10: 8993.

1936b. Wehrle's selamander, Plethodon wehrlei Fowler and

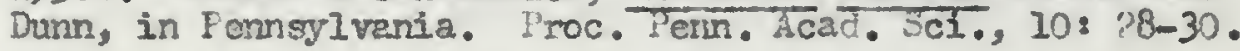

1939. The ravine salamander, Plethodon richnondi lletting and títtleman, in Pennsylvania. Proc. Penn. Acad. Sci., 13: $50-51$.

1946. The amphibians and reptiles of Pennsylvania. Comonwealth of Pennsylvania, Board of Fish Cormissioners: 1-29.

Netting, Graham, N. Bayard Green, and Neil D. Richnond

1946. The occurrence of Wehrle's salamander, Plethocion wehrlei Fonler and Dunn, in Virginia. Proc. BLOL.Joc. wash., 59: 157-160.

Heting, Graham, and H. B. littleman

1938. Description of Plethodon richmundi, a new salanander from West Virginia and ohlo. Ann. Camegie líus., 27: 287293, pl. 30 .

Nerman, valter $\bar{B}$.

1954. A new plethodontid salamander from southwestern Virginia. Herpetologica, $10(1): 9-14$.

Nicholls, J: C., Jr.

1950. Wutes on the salananders associated with Dosmomathus

occee Nicholls. Jour. Tenn. Acrd. Sci., 25 (L): 310-3II.

NobiLe, G. K.

1927. The plethodontid salamanders; some aspects of their evolution. Amer. liks. Nov., (249): 1-26: figs. 1-10.

Orton, Grace L.

1946. The size of the slimy salamander. Copeia (2): 107.

Par'ser, valcolm $\nabla$.

1937. Some amphibians and reptiles from Reelfoot Lake. Jour. Tenn. Acad. Sci., 12 (1): 60-56, figs. 1-18.

1939. The emphibians and reptiles of Reelfoot Lake and vicinity, with a key for the seraration of species ard subm species. Rept. Reelfoot lake Blol. St2., 3: 72-10l, figs. I-1L.

1948. A contribution to the herpetolocy of western lennessee. Jour. Tenn. Acad. Sci., 22: 20-30. 
Pope, Clifford H.

1924. Notes on North Carolina salamanders with especial reference to the egg-laying habits of Leurognathus and Desmognathus. Amer. Las. Nov., (153): 1-15, Pigs. 1-2.

1928. Some plethodontid salamanders from North Carolina and Kentucly with the description of a new race of Leurognathus. Amer. thus. Nov., (306): 1-19, fig. 1.

1950. A statistical and ecological study of the salamander Plethodon yonahlossee. Bull. Chicago Acad. Sci., 9 (5): 79-106, figs. $1-5$.

Pope, Clifford H., and James A. Fowler

1949. A new species of salamander (Plethodon) from southwestern Virginia. Nat. Ilist. Msc., Chicago Acad. Sc1., (47): 1-4.

Pope, Clifford H., and Nelson G. Hairston

1948. Two new subspecies of the salamander Plethodon shermani. Copeia (2): 106-107.

Pope, Clifford H., and Sarah H. Pope

1949. Notes on growth and reproduction of the sliny salam mander Plethodon Elutinosus. Fleldiana (Zoology), 31 (2.9): 251-261, IIgs. 60-55.

1951. A study of the salamander Plethocion ouachitae and the description of an allied form. Eull. Chiacgo head. Sci., 9 (8): 129-152, figs. 1-6.

Rabb, George B.

1955. Observations on the identity of the salamander Plethodon muldae. Copela (3): 261-262.

Rankin, J.S.

1937. An ecological study of parasites of some North Cara lina salamanders. Fcol. Honogr., 7 (2): 169-269, f1gs. 1-15.

Phoads, Sarnuel N.

1895. Contributions to the zoology of Tennessee. No. I. Reptilcs and amphibians. Proc. Acad. Nat. Sci. Phtla., 47: $376-407$.

Richroond, Neil D.

1952. First record of the green salamander in Pennsylvania, and other range extensions in Pennsylvania, Virglnia and West Virginia. Ann. Carnegle lius., 32 (7): 313-318, fig. 1.

Sager, Abram

1858. Description of a nem genus of perennt-branchiate amphibians. Peninsular Jour. Kedicine, $5(8):$ 428-429. 
Sanders, Ottys, and Hobart Hif. Sinth

1949. Some noteworthy records of amphibians in Texas.

Trans. Kansas Acad. Sc1., 52 (1): 28-29.

Savage, Jay $M$.

1952. The distribution of the Pacific giant salamander,

Dicamptodon ensatus, east of the Cascade liountains. Copeia

$(3): 183$.

Schmidt, Kari P.

1924. A list of amphibians and reptiles collected near

Charleston, S. C. Copeia (132): 67-69.

1953. A checkilst of North American armhibians and reptiles.

Sixth Ed. Amer. Soc. Ichthy. \& Herp.: vili, 1-280.

Schwartz, Albert

1953. A new subspecies of the crowned snake (Tantilla

coronata) from the southern Appalachian Mountains. HerpetoIog्धित, 9 (3): 153-157.

1954. The salamander Aneides aeneus in South Carolina. Copeia $(4): 296-298$.

Sinclair, Ralph 14 .

1950a. Notes on some salamanders from Tennessee. Herpetologica, $6(2): 49-51$.

1950b. Sore noteworthy records of amphiblans and reptiles

in Tennessee. Herpetologica, 6 (7): 200-202.

Slater, James $\mathrm{R}$.

1933. Wotes on Washington salamanders. Copeia $(1): 44$.

1934. Notes on northwestern amhibians. Copeia (3): 14a 141.

1939. Plethodon dunn in Oregon and Washington. Herpetolo gica, 1 (6): 154 .

1940. Salanander records from British Columbia. Occ. Papers Dept. Zool., College of Fuget Sound, (9): 43-44.

1941. The distribution of amphibians and reptiles in Idaho. Occ. Papers Dept. Biol., College of Purset Sound, (It): 78-109.

1955. Distribution of Washington amphibians. Oce. Papers

Dept. Biol., College of Puget Sound, (16): 133-154, figs. 1-2.

Slater, James R., and 霖. C. Brown

1947. Island records of amphibians and reptilos for Washington.

Occ. Papers Dopt. Hol., College of Fuget Sound, (13): 74-77. 
Slater, James R., and J. W. Slipp

1940. A new species of Plethodon from northem Idaho. Occ.

Fapors Dept. Biol., College of Fuget Sound, $(8): 38-43$, figs. $1-3$.

Slevin, J. R.

1928. The amphiblans of westem North Anerica. Occ. Papers Cal. Acad. Sc1., 16: 1-152, pls. 1-23.

1934. A handbook of reptiles and amplibians of the Pacific states. Spec. Fub. Cal. Ac8d. Sc1.: 1-73, pls. 1-73, figs. 1-9.

Srith, Hobart M., and H. K. Buechner

1947. The Influence of the Balcones Escarpment on the distribution of amphibians and reptiles in Texss. Bull. Chicago Acad. Sc1., 8 (1): 1-16, fig. 1.

Smith, Philip w.

1948. Noteworthy herpetological records from Illinois. Nat.

Hist. Mise., Chicago Acad. Sei., (33): I-L.

Snyder, Richard C.

1946. Plethodon welleri from Flat Top Lountain, North

Cerolina. Copeia (3): 174 .

Stebbins, Robert C.

1949. Speciation in salamanders of the plethodontid genus Ensat1na. Univ. Cal. Pub. Zool., $48(6): 377-525$, figs. 115, p1s. $1-6$.

1951. Amphibians of westem North America. Berkeley: University of California Press, ix, 1-539.

1954. Amphibians and reptiles of western North Anerica. New York: HeGraw-HIIl Book Co., Ine., xod1, 1-528.

Stebbins, Robert C., and H. C. Reynolds

1947. Southern oxtension of the range of the Del Norte salamander in California. Herpetologica, 4 (2): $41-4,2$.

Stebbins, Rovert C., and William J. Rioner

1950. A now species of plethodontid salamander from the Jemez Mountains of New Mexico. Copeia (2): 73-80, pls. $1-2$.

Stejneger, Ieonhard

1906. A new salamander Prom North Carolina. Proc. U. S. Nat. Hus., 30: 559-562, figs. 1-6.

SteJneger, Leonhard, and Thomas Barbour

1917. A check list of IIorth American amphibians and reptiles. Cambridge: Harvard University Press: 1-126. 
Storer, Tracy I.

1925. A synopsis of the Amphibia of Califormia. Univ.

Cal1f. Pub. Z001., 27: 1-3142, figs. 1-42, pls. 1-18.

Storm, Robert $M$.

1955. Northern and scuthern range limits of Dunn's salam mander, Plethodon dunni. Copeia (1): 64-65.

Strauch, Alexander

1870. Revision der Salamandrider-Gattungen. Memolres do

I'Acad. Imp. Sci. St. Petersbourg, ser. 7, 16 (4): 1-110, pls. $1-2$.

Strecker, J. K.

1902. A preliminary report on the reptiles and batrachians of McLennan County, Texas. Tran. Texas Acad. Sci. For 1901, $4(2): 95-101$.

1908. The reptiles and batrachians of McLennan County, Texas. Proc. Biol. Soc. Tiash., 21: 69-83.

1915. Reptiles and amphibians of Texas. Baylor Bull., 18 (4): $1-82$.

1935. The reptiles of West Frio Canyon, Real County, Texas. Baylor Bull., 38 (3): 32 .

Svihla, Arthur

1933. Extension of the ranges of some washington Amphibia. Copeia (1): 39.

Swanson, Paul L.

1939. Horpetological notes from Indiana. Aner. klidland Nat.,

22. (3): 68lt-695, pls. 1-3, map.

Thurow, Gordon ‥

1951. An anelysis of variations in the pigmentation of Plethodon giutinosus. Unpublished Utaster's Thesis, Univer sity of Chicago.

1955a. An albinistic individual of the salamander Plothodon dorsalis. Copela (1): 62-63, pl. 1 .

1955b. P1ethodon nettingi in Virginia. Herpetologica, 11

(2): $102-103$.

Tschudi, J. J.

1838. Classification der Batrechier mit Borlicksichtigung der fossilen Thiere dieser Abtheilung. Men. Soc. Sci. Nat. Neuchatel., 2: 1-100. 
Van Denburgh, Iohn

1906. Description of a now species of the genus Plethodon

(Plethodon vandyke1) fron hount Ranier, Washington. Proc. ca].11. Hcad. Sc1., $4(4): 61-63$.

1916. Four specles of salamanders nev to the state of

California, with a description of Plethodon elongetus, a nev species, and notes on other salamanders. Yroc. Calif. Acad. Sci., $6(7): 215-221$.

Villalobos-Dordnguez, C., and Julto Villalobos

1947. Atlas de los colores. Buenos Aires: $74 \mathrm{pp} ., 38 \mathrm{pls}$.

Walker, Charles F.

1931. Description of a nev salamander from North Carolina.

Proc. Junior Soc. Nat. Soi., Cincinnati, 2: 48-51.

1933. Some new amphibian records for Ohio. Copela (4): 224.

1934. Plethodon welleri at wite Top Mountain, Virginia. Copela (4): 190 .

Watrey, Gertride $S$.

1938. A new record of Plethodon vehlculus (Cooper) from

Vancouver, British Columbia. Copela (2): 89.

Weller, W. H.

1931. A preliminary list of the salananders of the Great

Snoky Mts. of North Carolina and Tennessee. Froc. Junior

Soc. Nat. Hist., Cincinnat1, 2 (1): 21-32.

Thed, Max P. zu

1865. Verzeichniss der Reptilien welche auf einer Reise im

nurditchen Arerica beobachtet wurden. Nov. Act. Acad. Leopold

Caro1. Nat. Curios, 32: 1-14h, pls. 1-7.

Wood, John Thornt on

1945a. Ovarian eggs in Plethodon richmondi. Herpetologica,

2: $206-210$.

1945b. Plethodon richmondi in Greene County, Ohio. Copela

(1): 46 .

1946. Additional records of Plethodon richmondi. Copela (3): 169.

1947a. Juveniles of Plethodon Jordani Blatchley. Herpetolo gica, 3 (6): 185-188, 1'1g. I

1947b. Description of Juvenile Plethodon glutinosus shermani Stejneger. Herpetologica, $3(6): 188$.

1947c. Notes on North Carolina salamanders. Copeia (4): 273274 . 
Wood, John Thomton, and William E. Drallman

1947. Prelininary herpetological survey of liontgonery

County, ahio. Herpetologica, $4: 3-6$.

liood, Plallace F.

1934. Notes on the salamander, Plethodon elongatus. Copeia

(4): 191 .

1939. Ampibian records from northwestem Californta. Copeia (2): 110 .

Wright, Albert $H_{0}$, and A. A. right.

1938. Amphibians of Texas. Tran. Tcxas Acad. Sci., 21:

1-38, figs. 1-6, pls. 1-3. 


\section{BICLPAPHICAL ITTHS}

Richard Highton was born on December 24, 1927, in Chicago, Illinols. He graduated from the Bronx High School of Science in New Iork C1ty in June, 1945. He received the Bachelor of Arts degree with a major in biology Irom the University College of Arts and Sciences, New Iork University, In October, 1950.

He entered the Untversity of Florida in September, 1951, and received the llaster of science degree in biology in June, 1953.

He served as a graduate assistant in the Department of Hology at the University of Florlda from July, 1952, to January, 1954. From February to June, 1954, he held a graduate fellowship. From Septenber, 195h, to the present, he has been a teaching assistant in the Dopartment of Biological Science. During the summer of 1955 , he was employed as a Ranger-liaturallst by the Great Smoky lountains National Park.

He is a member of the American Society of Ichthyologists and Herpetologists, the herpetologIsts League, and SIgma Xi. 
This dissertation was prepared under the direction of the chairman of the candidate's supervisory committee and has been approved by all members of the committee. It was submitted to the Dean of the College of Arts and Sciences and to the Graduate Council and was approved as partial fulfillment of the requirements for the de gree of Doctor of Philosophy.

June 4,1956

Donn, College of Arts and sciences

Dean, Graduate School

SUPERVISORY CORMITITE:

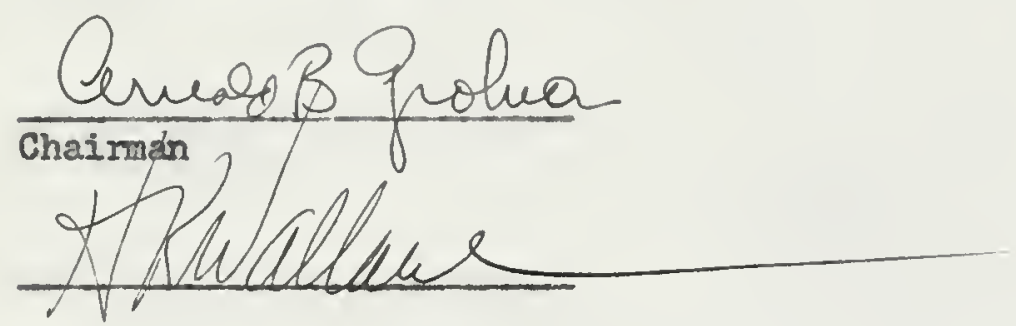

Pocket \&. Baber

A Cideniven fo

Hectic Car 
